Review

\title{
Does the Polypill Improve Patient Adherence Compared to Its Individual Formulations? A Systematic Review
}

\author{
Ana Baumgartner ${ }^{1,2, * \mathbb{D}}$, Katarina Drame ${ }^{1,2}$, Stijn Geutjens ${ }^{1,3}$ and Marja Airaksinen ${ }^{1}$ \\ 1 Division of Pharmacology and Pharmacotherapy, Faculty of Pharmacy, University of Helsinki, \\ 00014 Helsinki, Finland; katarina.drame@gmail.com (K.D.); stijngeutjens@gmail.com (S.G.); \\ marjaairaksinen@gmail.com (M.A.) \\ 2 Faculty of Pharmacy, University of Ljubljana, 1000 Ljubljana, Slovenia \\ 3 Faculty of Pharmaceutical Sciences, Katholieke Universiteit Leuven, 3000 Leuven, Belgium \\ * Correspondence: baumgartner.ana@gmail.com
}

Received: 17 January 2020; Accepted: 20 February 2020; Published: 22 February 2020

\begin{abstract}
Many patients, especially those with a high pill burden and multiple chronic illnesses, are less adherent to medication. In medication treatments utilizing polypills, this problem might be diminished since multiple drugs are fused into one formulation and, therefore, the therapy regimen is simplified. This systematic review summarized evidence to assess the effect of polypills on medication adherence. The following databases were searched for articles published between 1 January 2000, and 14 May 2019: PubMed, Web of Science, Cochrane Library, and Scopus. Medication adherence was the only outcome assessed, regardless of the method of measuring it. Sixty-seven original peer-reviewed articles were selected. Adherence to polypill regimens was significantly higher in 56 articles (84\%) compared to multiple pill regimens. This finding was also supported by the results of 13 out of 17 selected previously published systematic reviews and meta-analyses dealing with this topic. Adherence can be improved through the formulation of polypills, which is probably why the interest in researching them is growing. There are many polypills on the market, but the adherence studies so far focused mainly on a small range of medical conditions.
\end{abstract}

Keywords: polypill; fixed-dose combination; adherence; systematic review

\section{Introduction}

Poor medication adherence is a widespread and unresolved challenge among patients [1]. Only half of the prescribed doses are taken, and many patients stop their treatment before the planned end of the therapy [1-3]. Several factors contribute to low adherence rates, such as ineffective communication between the patient and the physician, or patients perceive their treatment as unnecessary. Patients may also think the benefits of their pharmacotherapy do not outweigh its adverse effects, or they simply forget [4]. This very often results in complications, extra healthcare costs, side effects, and therapeutic failures. Therefore, improving adherence is a crucial factor in increasing the likelihood of positive therapeutic outcomes.

Patients with chronic illnesses must quite often take multiple pills every day for months or even years, which will eventually result in less adherence to their medication [5]. This occurs especially in cardiovascular diseases (CVD), where patients do not feel the symptoms of their disease in the short term, and it is easier for them to forget to take their medicines [6]. The same goes for diabetes patients; in mild forms, diabetes does not cause serious complications, and patients do not feel ill; thus, they tend to forget their medication [7]. 
Polypills are a technological innovation that is expected to improve adherence by simplifying the pharmacotherapy regimen [2,5]. The concept of the polypill, very often referred to as a fixed-dose combination (FDC), is quite simple. Instead of taking two or more pills (each containing one active ingredient), multiple drugs are combined into one formulation $[6,8,9]$. It is generally thought that taking fewer pills will lead to better adherence [2]. This systematic review examines the evidence for that idea and assesses the evidence of the effects of a reduced pill burden on medication adherence.

\section{Materials and Methods}

\subsection{Search Strategy}

This systematic review is focused on articles concerning fixed-dose combinations (FDCs), also known as polypills, in comparison to their separate drug formulations (multiple tablets, free-pill combinations). It does not matter how many drugs are combined in a certain formulation.

The method followed the Preferred Reporting Items for Systematic Reviews and Meta-Analyses (PRISMA) statement [10]. The search was done in May 2019, and it covered the following databases: PubMed, Web of Science, Cochrane Library, and Scopus. After screening all titles and articles, the reference lists of selected articles were used to identify additional relevant studies.

In all four databases, the following selection of keywords was applied: (compliance OR adherence OR non-compliance OR non-adherence OR noncompliance OR nonadherence) AND ((fixed NEAR/1 combination*) OR single-pill* OR single-tablet* OR polypill* OR “combination pill"*). The principle behind this selection was to make an extensive search that would cover only the relevant articles by using as many synonyms and antonyms for two terms related to the aim of our study: polypills and adherence. The search included a language filter, which showed only articles written in English. Furthermore, a time-span filter was used, which included only articles published since 1 January 2000.

\subsection{Inclusion and Exclusion Criteria}

Articles were included in the systematic review if they were either original peer-reviewed studies or systematic reviews and meta-analyses. Narrative reviews and conference abstracts were excluded. There were no restrictions concerning the type of patients, diseases, comorbidities, or drugs. Adherence was the only essential outcome measure for an article to be considered, regardless of how it was measured. Other outcomes were not assessed. All articles needed to have a comparison between low and high pill burden groups, meaning that one group had to take more pills than another group. This was possible either with control groups (longitudinal, controlled) or when observing one group with patients who changed their pill burden over time (longitudinal, uncontrolled). It was also necessary that the articles dealt with solid dosage formulations rather than with any other dosage form.

Additionally, articles dealing with persistence instead of adherence were excluded. The definitions of these two terms are vague since they stand for a similar phenomenon and, thus, they tend to overlap in different literature. However, for this study, only articles measuring adherence were included, and the ones that clearly stated that they dealt only with persistence were excluded.

\subsection{Study Selection and Data Extraction}

Both researchers (A.B. and K.D.) searched for the articles separately to make the most credible and objective article selection. Their findings were then compared, and discussions were held until a final decision about included articles was reached.

Key information about all relevant studies was extracted from the articles. For original peer-reviewed studies, the extracted information included author of the study, year of publication, study country, design, setting, aim and population, disease in question, follow-up period, adherence measures, main outcomes, number and international nonproprietary names (INN) of active ingredients used in the study, and their dosage (if given). For systematic reviews and meta-analyses, the extracted data covered the author of the study, year of publication, medical condition in focus, study aim, number 
of included original studies, and main results. For further working progress, articles were grouped by (i) article type, that is, original studies separately from systematic reviews and meta-analyses, and (ii) the type of disease they were dealing with.

\subsection{Quality Assessment}

Quality assessment of the included studies was systematically done using Cochrane Collaboration's risk of bias assessment tool for randomized controlled trials [11] and the Newcastle-Ottawa scale for cohort studies [12]. As adherence was the only outcome of interest, assessment of how any other outcomes were dealt with was ignored.

Cochrane Collaboration's risk of bias tool measures risk of bias in randomized controlled trials through seven domains: sequence generation and allocation concealment (selection bias), blinding of participants (performance bias), blinding of outcome assessment (detection bias), incomplete outcome data (attrition bias), selective reporting (reporting bias), and other bias. Each domain is assessed as having high, low, or unclear risk of bias. Studies with low risk of bias for all criteria were considered to be of low risk, studies with low or unclear risk of bias were considered medium risk, and studies with at least one domain assessed as high risk of bias were considered as having an overall high risk of bias [11]. However, as all randomized controlled trials were inherently open-label, meaning that blinding of participants was impossible due to the nature of the intervention, this domain was always assessed as having a high risk of bias and, therefore, omitted from the overall evaluation of studies.

The Newcastle-Ottawa scale was used for observational studies; it measures quality through three main domains: selection, comparability, and outcome. Each study was awarded a maximum of nine stars, depending on whether it reached certain standards within these domains (maximum four stars for selection, two stars for comparability, and three stars for outcome) [12]. Studies with 0-4 stars were considered as low quality, studies with 5-7 stars were considered as medium quality, and studies having eight or nine stars were considered as high quality.

\section{Results}

The database search yielded 5170 records, of which 2287 were screened after removal of duplicates and inclusion of time-span and language filters. After the inclusion and exclusion criteria were applied to screen the records, 84 articles were included in our systematic review; 67 of them were original peer-reviewed studies and 17 were systematic reviews and/or meta-analyses. For the flow chart of the article selection process, see Figure 1.

\subsection{Included Systematic Reviews and Meta-Analyses $(n=17)$}

After the selection process of eligible studies, 17 systematic reviews and/or meta-analyses out of 136 articles were included in this systematic review (Figure 1, Table A1, Appendix A). Of these studies, eight were meta-analyses (47\%) [13-20], two were systematic reviews (12\%) [21,22], and seven were defined as a systematic review with meta-analysis (41\%) [23-29]. The most common systematically reviewed medical condition was hypertension $(n=5,29 \%)$ [14-16,25,26], followed by studies dealing with CVDs in general $(n=3,18 \%)[17,18,21]$, human immunodeficiency virus (HIV) $(n=4,24 \%)[19,20,24,27]$, diabetes $(n=2,12 \%)$ [22,28], and tuberculosis $(n=1,6 \%)$ [23] (Table 1). Two studies examined the effect of polypills in several medical conditions $[13,29]$. Thirteen of the selected articles $(76 \%)$ favored therapy with FDC over separate-pill therapy regimens [13-16,18-22,24,25,27,28]. 

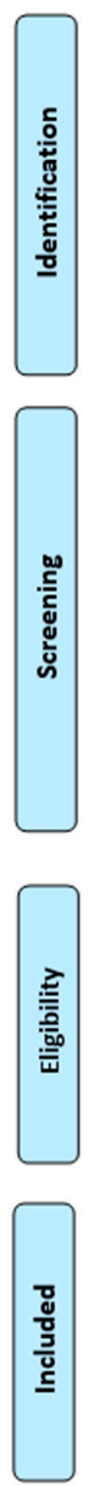

Records identified through database searching: 5170 Web of Science: 1525 Scopus: 2193

Pubmed: 1135 Cochrane Library: 317

Figure 1. Preferred Reporting Items for Systematic Reviews and Meta-Analyses (PRISMA) flow chart of the article selection.

Table 1. Summary of conclusions per disease in previously published systematic reviews and meta-analyses $(n=17)$.

\begin{tabular}{ccccc}
\hline \multirow{2}{*}{ Disease } & Conclusions Concerning & \multicolumn{3}{c}{ Study Design [Reference] } \\
\cline { 3 - 4 } & Adherence to FDCT & Meta-Analysis & $\begin{array}{c}\text { Systematic Review } \\
\text { with Meta-Analysis }\end{array}$ & $\begin{array}{c}\text { Systematic } \\
\text { Review }\end{array}$ \\
\hline Various diseases $(n=2)$ & FDCT $>$ MPT $(n=1)$ & {$[13]$} & \\
Inconclusive $(n=1)$ & & {$[29]$} \\
Hypertension $(n=5)$ & FDCT $>$ MPT $(n=4)$ & {$[14-16]$} & {$[25]$} \\
CVD $(n=3)$ & Inconclusive $(n=1)$ & & {$[26]$} \\
HIV $(n=4)$ & FDCT $>\operatorname{MPT}(n=2)$ & {$[18]$} & {$[21]$} \\
Diabetes $(n=2)$ & FDCT $=\operatorname{MPT}(n=1)$ & {$[17]$} & {$[24,27]$} \\
Tuberculosis $(n=1)$ & FDCT $>\operatorname{MPT}(n=4)$ & {$[19,20]$} & {$[28]$} \\
\hline
\end{tabular}

FDCT, fixed-dose combination therapy; MPT, multipill therapy; CVD, cardiovascular disease; HIV, human immunodeficiency virus. 
However, some overlap of the articles that these studies investigated was found. For example, Selak et al. [17] and Webster et al. [18] included the same studies, which were also included by Bahiru et al. [21] Furthermore, there is much overlap between studies conducted by Gupta et al. [16], Kawalec et al. [25], Sherrill et al. [15], and Du et al. [14]. Both studies conducted by Clay et al. [20,24] share some of the included articles as well. For a visual representation of the overlap of the studies included in the abovementioned systematic reviews and meta-analyses, please see Figure 2.

\begin{tabular}{|l|l|l|l|l|l|l|l|l|l|l|l|l|}
\hline van Galen 2014 & & & & & & & & & & & & \\
\hline Bangalore 2007 & & & & & & & & & & & & \\
\hline Kawalec 2018 & & & & & & & & & & & & \\
\hline Du 2018 & & & & & & & & & & & & \\
\hline Sherrill 2011 & & & & & & & & & & & & \\
\hline Gupta 2009 & & & & & & & & & & & & \\
\hline Mallat 2016 & & & & & & & & & & & & \\
\hline Selak 2018 & & & & & & & & & & & & \\
\hline Bahiru 2017 & & & & & & & & & & & & \\
\hline Webster 2016 & & & & & & & & & & & & \\
\hline Han 2012 & & & & & & & & & & & & \\
\hline Hutchins 2011 & & & & & & & & & & & & \\
\hline Altice 2019 & & & & & & & & & & & & \\
\hline Clay 2018 & & & & & & & & & & & & \\
\hline Clay 2015 & & & & & & & & & & & & \\
\hline Ramjan 2014 & & & & & & & & & & & & \\
\hline Albanna 2013 & & & & & & & & & & & & \\
\hline
\end{tabular}

Figure 2. Visual representation of the overlap of the studies included in other systematic reviews and meta-analyses (SR and MA; $n=17$ ). One row represents one SR/MA. Each colored square symbolizes one article, and the number of colored squares is equal to the number of studies included in the corresponding SR/MA. Different colors represent into how many SRs/MAs an article was included (e.g., if all the colored squares in a row are blue, all the articles are unique to only this SR/MA). Blue: study included only in one SR/MA. Red: study included in two different SRs/MAs. Yellow: study included in three different SRs/MAs. Green: study included in four different SRs/MAs. Purple: study included in five different SRs/MAs.

Some of the studies investigated in one or more of the previously published systematic reviews and meta-analyses were also included in our systematic review since they fit the inclusion criteria [5,30-57].

\subsection{Included Original Peer-Reviewed Studies $(n=67)$}

Altogether, 67 original peer-reviewed studies out of a total of 5170 articles met the inclusion criteria and were included in our study (Figure 1). Of the 67 articles, 31 (46\%) were related to hypertension (HT), $14(21 \%)$ were related to human immunodeficiency virus (HIV), 11 (16\%) were related to cardiovascular disease (CVD), 10 (15\%) were related to diabetes mellitus type II (DMII), and one dealt with lower urinary tract symptoms associated with benign prostatic hyperplasia (LUTS/BHP). Studies were conducted in different countries worldwide; some of them even included more than one country. Most of them $(n=36)$ were conducted in the United States, and only one was carried out in South America, in two different countries. More details can be found in Table 2. 
Table 2. General information about reviewed articles $(n=67)$.

\begin{tabular}{|c|c|c|}
\hline $\begin{array}{l}\text { Information of } \\
\text { Interest }\end{array}$ & $\begin{array}{l}\text { Result (Number of Studies with } \\
\text { a Certain Feature) }\end{array}$ & References \\
\hline \multirow{5}{*}{ Disease } & $\operatorname{CVD}(n=11)$ & {$[35,45,48,49,52,58-63]$} \\
\hline & HT $(n=31)$ & {$[5,33,38-42,46,53,55,56,64-83]$} \\
\hline & $\operatorname{DMII}(n=10)$ & {$[31,32,36,43,44,51,54,84-86]$} \\
\hline & $\operatorname{HIV}(n=14)$ & {$[30,34,37,47,50,57,87-94]$} \\
\hline & LUTS/BHP $(n=1)$ & [95] \\
\hline \multirow{21}{*}{$\begin{array}{l}\text { Country where } \\
\text { the study was } \\
\text { conducted (in } \\
\text { alphabetical } \\
\text { order) }\end{array}$} & Argentina $(n=1)$ & [35] \\
\hline & Australia $(n=3)$ & {$[45,58,61]$} \\
\hline & Austria $(n=1)$ & [66] \\
\hline & Belgium $(n=2)$ & {$[66,88]$} \\
\hline & France $(n=1)$ & [59] \\
\hline & Germany $(n=4)$ & {$[7,66,67,79]$} \\
\hline & Greece $(n=1)$ & [85] \\
\hline & India $(n=1)$ & [52] \\
\hline & Ireland $(n=1)$ & [52] \\
\hline & Italy $(n=8)$ & {$[35,40,42,69,70,84,87,92]$} \\
\hline & Japan $(n=2)$ & {$[73,75]$} \\
\hline & Korea $(n=1)$ & [64] \\
\hline & The Netherlands $(n=5)$ & {$[52,59,66,88,95]$} \\
\hline & New Zealand $(n=1)$ & [48] \\
\hline & Paraguay $(n=1)$ & [35] \\
\hline & Romania $(n=1)$ & [77] \\
\hline & Spain $(n=2)$ & {$[35,90]$} \\
\hline & Switzerland $(n=1)$ & [66] \\
\hline & Taiwan $(n=5)$ & {$[5,53,71,78,80]$} \\
\hline & $\mathrm{UK}(n=1)$ & [52] \\
\hline & USA $(n=36)$ & $\begin{array}{c}{[30-34,36-39,41,43,44,46,49-51,54-57,60,62,63,65,68,72,74,76,81-83,86,} \\
89,91,93,94]\end{array}$ \\
\hline \multirow{17}{*}{$\begin{array}{l}\text { Follow-up } \\
\text { period (given } \\
\text { as the exact, } \\
\text { average, or } \\
\text { minimal value, } \\
\text { depending on } \\
\text { the study) }\end{array}$} & 6 weeks $(n=1)$ & [91] \\
\hline & 2 months $(n=4)$ & {$[37,57,89,93]$} \\
\hline & 3 months $(n=1)$ & [73] \\
\hline & 18 weeks $(n=1)$ & [59] \\
\hline & 24 weeks $(n=1)$ & [85] \\
\hline & 6 months $(n=16)$ & {$[30,32,42-44,46,51,54,55,58,66,68,70,72,75,87]$} \\
\hline & 9 months $(n=1)$ & {$[35]$} \\
\hline & 12 months $(n=26)$ & {$[31,33,36,38-41,48,49,52,56,60,62,64,65,67,71,74,76,80-84,86,95]$} \\
\hline & 15 months $(n=1)$ & [78] \\
\hline & 18 months $(n=3)$ & {$[34,45,50]$} \\
\hline & 1.7 years $(n=1)$ & [94] \\
\hline & 96 weeks $(n=1)$ & [90] \\
\hline & 24 months $(n=5)$ & {$[5,53,61,69,88]$} \\
\hline & 33 months $(n=1)$ & [47] \\
\hline & 36 months $(n=1)$ & [63] \\
\hline & 4 years $(n=1)$ & [77] \\
\hline & 5 years $(n=2)$ & {$[79,92]$} \\
\hline \multirow{6}{*}{$\begin{array}{c}\text { Year of } \\
\text { publication }\end{array}$} & $2002-2004(n=3)$ & {$[32,43,49]$} \\
\hline & 2005-2007 $(n=4)$ & {$[40,54,60,89]$} \\
\hline & $2008-2010(n=15)$ & {$[30,33,36,38,39,41,44,46,51,55,56,62,68,72,87]$} \\
\hline & $2011-2013(n=10)$ & {$[31,34,37,52,63,65,73,75,83,84]$} \\
\hline & $2014-2016(n=22)$ & {$[5,35,42,45,47,48,50,57-59,66,70,76,78,80-82,85,86,88,91,93]$} \\
\hline & $2017-2019(n=13)$ & {$[14,53,61,64,69,71,74,77,79,90,92,94,95]$} \\
\hline \multirow{3}{*}{ Study design } & Randomized clinical study $(n=7)$ & {$[35,45,48,52,59,75,88]$} \\
\hline & Retrospective cohort study $(n=52)$ & {$[5,31-33,36-44,46,47,49-51,53-58,60-65,67-72,74,76-84,86,89,92-95]$} \\
\hline & Prospective cohort study $(n=8)$ & {$[30,34,66,73,85,87,90,91]$} \\
\hline
\end{tabular}


Table 2. Cont

\begin{tabular}{|c|c|c|}
\hline $\begin{array}{l}\text { Information of } \\
\text { Interest }\end{array}$ & $\begin{array}{c}\text { Result (Number of Studies with } \\
\text { a Certain Feature) }\end{array}$ & References \\
\hline \multirow{5}{*}{$\begin{array}{l}\text { Number of } \\
\text { drugs in the } \\
\text { polypill } \\
\text { examined in } \\
\text { the study }\end{array}$} & Two drugs $(n=41)$ & {$[5,31-33,36,38-44,46,49,51,53-56,58,60-65,67-73,75,78-80,83,85,89,95]$} \\
\hline & Three drugs $(n=11)$ & {$[30,34,35,37,47,50,66,81,82,87,88]$} \\
\hline & Four drugs $(n=5)$ & {$[45,48,52,59,90]$} \\
\hline & Five drugs $(n=1)$ & [57] \\
\hline & Not mentioned $(n=9)$ & {$[74,76,77,84,86,91-94]$} \\
\hline
\end{tabular}

CVD, cardiovascular disease; DMII, diabetes mellitus type 2; LUTS/BHP, lower urinary tract symptoms associated with benign prostatic hyperplasia; HT, hypertension; HIV, human immunodeficiency virus; UK, United Kingdom; USA, United States of America.

A summary of these 67 studies can be found in Table A2 (Appendix B), displaying author, year of publication, country of the study, study design, study aim, study setting and follow-up period, study population, outcome measures, and results.

Most of the studies ( $n=41 ; 61 \%)$ examined the effects of treatment with polypills, where only two drugs were combined (see Tables 2 and 3). However, in HIV therapy, the use of three-drug formulations was dominant over any other (seven out of 14 studies). There were no data on combining more than five drugs into one formulation. Additional information about the combinations of active ingredients in polypills can be found in Table A3 (Appendix C).

Table 3. Visualization of number of active ingredients contained in a polypill. Written in the table are numbers of the studies with the given characteristics (disease and number of active ingredients in the polypill).

\begin{tabular}{|c|c|c|c|c|c|}
\hline \multirow[t]{2}{*}{ Disease } & \multicolumn{5}{|c|}{$\begin{array}{l}\text { Number of Studies Dealing with a Polypill } \\
\text { Containing a Given Number of Active Ingredients }(2,3,4,5 \text {, or Not Mentioned) }\end{array}$} \\
\hline & II & III & IV & $\mathrm{V}$ & Not mentioned \\
\hline CVD & $6[49,58,60-63]$ & $1[35]$ & $4[45,48,52,59]$ & 0 & 0 \\
\hline HT & $\begin{array}{c}25 \\
{[5,33,38-42,46,53,56,64} \\
65,67-73,75,78-80,83,94]\end{array}$ & $3[66,81,82]$ & 0 & 0 & $3[74,76,77]$ \\
\hline DMII & $\begin{array}{c}8 \\
{[31,32,36,43,44,51,54,85]}\end{array}$ & 0 & 0 & 0 & $2[84,86]$ \\
\hline HIV & 1 [89] & $\begin{array}{l}7[30,34,37,47 \\
50,87,88]\end{array}$ & $1[90]$ & $1[57]$ & 4 [91-94] \\
\hline LUTS/BPH & $1[95]$ & 0 & 0 & & 0 \\
\hline Sum & 41 & 11 & 5 & 1 & 9 \\
\hline
\end{tabular}

CVD, cardiovascular disease; DMII, diabetes mellitus type 2; LUTS/BHP, lower urinary tract symptoms associated with benign prostatic hyperplasia; HT, hypertension; HIV, human immunodeficiency virus.

\subsection{Adherence Measures Used in the Studies $(n=67)$}

Table 4 summarizes methods for measuring adherence that were used in the selected articles $(n=67)$. Most of the studies $(n=62 ; 93 \%)$ relied only on one method; however, five studies $[35,50,59,79,82]$ combined two different methods to assess medication adherence. The applied methods could be divided into two broad categories: subjective (e.g., patient interviews and self-reporting) and indirect (e.g., pill counts, methods using prescription fills, electronic monitoring) [75]. Some of the methods are more general and applicable to more cases, whereas some were used only in a specific study. The most commonly used measure was medical possession ratio (MPR; $n=30,45 \%$ ), followed by proportion of days covered (PDC; $n=21,31 \%$ ). 
Table 4. Methods for measuring adherence applied in the articles $(n=67)$.

\begin{tabular}{|c|c|c|c|c|}
\hline Method & $\begin{array}{l}\text { Study-Specific/ } \\
\text { General }\end{array}$ & Short Description & Assessment of Level of Adherence & $\begin{array}{l}n \text { of Studies } \\
\text { [References] }\end{array}$ \\
\hline $\begin{array}{l}\text { Medication possession } \\
\text { ratio (MPR) }\end{array}$ & General & $\begin{array}{l}\text { Uses pharmacy prescription claims calculated } \\
\text { as the number of days' supply divided by the } \\
\text { number of days between the first refill and the } \\
\text { end of the follow-up period }\end{array}$ & $\begin{array}{c}\text { Low adherence: } \mathrm{MPR}<0.5 \\
\text { Intermediate adherence: } \mathrm{MPR}=0.5-0.8 \\
\text { High adherence: } \mathrm{MPR}>0.8\end{array}$ & $\begin{array}{c}n=30 \\
{[5,31-33,36,39-41,43,} \\
44,49-51,54,55,57,58, \\
60,62-64,67,80,82,84, \\
86,89,91,94,95]\end{array}$ \\
\hline $\begin{array}{l}\text { Proportion of days } \\
\text { covered (PDC) }\end{array}$ & General & $\begin{array}{l}\text { Uses prescription claims data; every day has to } \\
\text { be covered by the medication; coverage is } \\
\text { calculated based on the refill data. } \\
\text { For example, if the patient has } 30 \text { pills in his } \\
\text { prescription (1/day) and he gets a refill after } \\
40 \text { days, his PDC is } 30 / 40 \text { or } 75 \% \text {. }\end{array}$ & A PDC of $>80 \%$ is considered adherent. & $\begin{array}{c}n=21 \\
{[38,42,46,53,56,61,65,} \\
68-72,74,76,78,79,81- \\
83,90,93]\end{array}$ \\
\hline Pill count & General & $\begin{array}{l}\text { Healthcare professional pays an unexpected } \\
\text { visit to the patient's home and counts the pills } \\
\text { left; difference between the number of pills } \\
\text { dispensed and the number of pills not taken } \\
\text { gets divided by number of prescribed pills. }\end{array}$ & $\begin{array}{l}\text { Patient is considered adherent, if the } \\
\text { percentage is between } 80 \% \text { and } 110 \% \text {. }\end{array}$ & $\begin{array}{c}n=6 \\
{[30,35,47,73,75,91]}\end{array}$ \\
\hline Morisky scale & General & $\begin{array}{l}\text { Questionnaire containing eight questions; } \\
\text { a self-assessment scale. }\end{array}$ & Based on the sum of the scores. & $\begin{array}{c}n=3 \\
{[35,59,66]}\end{array}$ \\
\hline Self-reporting & Study-specific & $\begin{array}{l}\text { 1. Asking the patients about the names and } \\
\text { dosages of all drugs that are currently } \\
\text { taken [48]. } \\
\text { 2. Self-reported use of indicated combination } \\
\text { treatment (antiplatelet, statin, and } \geq 2 \\
\text { blood-pressure-lowering therapies for } \geq 4 \text { of } \\
\text { the previous seven days) [45,52]. } \\
\text { 3. Self-reporting of missed doses at each } \\
\text { medical visit [50]. } \\
\text { 4. Completing a compliance } \\
\text { questionnaire-nine questions about the } \\
\text { names and dosages of all drugs, missing doses, } \\
\text { treatment interruptions, etc. [85] }\end{array}$ & $\begin{array}{l}\text { 1. Adherent: patients reported taking } \\
\text { an antiplatelet, statin, and two or more } \\
\text { blood-pressure-lowering drugs. } \\
\text { Non-adherent: patients who forgot one or } \\
\text { more drugs. } \\
\text { 2. Level of adherence not assessed. } \\
\text { 3. It was assumed that each day of ART missed } \\
\text { was an additional } \\
\text { day between refills of a 30-day supply } \rightarrow \text { MPR } \\
\text { method was applied. } \\
\text { 4. Adherent: not missing any drug dose or no } \\
\text { more than } 2 \text { doses per week, received the } \\
\text { correct dosage of the medication, and not } \\
\text { interrupting their treatment. }\end{array}$ & $\begin{array}{c}n=5 \\
{[45,48,50,52,85]}\end{array}$ \\
\hline
\end{tabular}


Table 4. Cont

\begin{tabular}{|c|c|c|c|c|}
\hline Method & $\begin{array}{c}\text { Study-Specific/ } \\
\text { General }\end{array}$ & Short Description & Assessment of Level of Adherence & $\begin{array}{c}n \text { of Studies } \\
\text { [References] }\end{array}$ \\
\hline $\begin{array}{l}\text { Visual Analog Scale } \\
\text { (VAS) }\end{array}$ & General & $\begin{array}{l}\text { Uses information given by the patient who } \\
\text { performs self-assessment of adherence on } \\
\text { a scale } 0-100 .\end{array}$ & $\begin{array}{l}\text { Non-adherent: } 0 \\
\text { Perfectly adherent: } 100\end{array}$ & $n=2[34,87]$ \\
\hline $\begin{array}{l}\text { Simplified Medication } \\
\text { Adherence } \\
\text { Questionnaire (SMAQ) }\end{array}$ & General & $\begin{array}{l}\text { Self-reported questionnaire focused on HIV } \\
\text { patients, containing six items. }\end{array}$ & $\begin{array}{l}\text { Method of assessment is not given in } \\
\text { the article. }\end{array}$ & $n=1[88]$ \\
\hline $\begin{array}{l}\text { Prescription records } \\
\text { review }\end{array}$ & Study-specific & $\begin{array}{l}\text { Computing the total number of consecutive } \\
\text { months that was covered by antihypertensive } \\
\text { prescriptions during the study; adherence is } \\
\text { expressed as percentage of time. }\end{array}$ & $\begin{array}{c}\text { Low adherence: }<20 \% \\
\text { Medium adherence: } 20-79 \% \\
\text { High adherence: } \geq 80 \%\end{array}$ & $n=1[77]$ \\
\hline $\begin{array}{l}\text { Electric adherence } \\
\text { monitoring }\end{array}$ & $\begin{array}{l}\text { General principle, } \\
\text { study-specific } \\
\text { design (depends } \\
\text { on the dosage } \\
\text { form, dosage } \\
\text { regimen, etc.) }\end{array}$ & $\begin{array}{l}\text { The medication vial was closed with a cap } \\
\text { containing a microprocessor, which was } \\
\text { recording date and time of all openings. } \\
\text { The vial was filled with the exact amount of } \\
\text { medication required for the complete } \\
\text { treatment period. The participant was } \\
\text { instructed not to open the vial except when } \\
\text { taking the medication according to the } \\
\text { prescribed regimen. }\end{array}$ & $\begin{array}{l}\text { Based on whether the patient was taking the } \\
\text { doses daily and according to the schedule. }\end{array}$ & $n=1[59]$ \\
\hline $\begin{array}{l}\text { Time to the first instance } \\
\text { to discontinuation * }\end{array}$ & $\begin{array}{l}\text { General method, } \\
\text { study-specific } \\
\text { definition }\end{array}$ & $\begin{array}{l}\text { Defined as no repeat of prescription within } \\
150 \% \text { of the previous days' supply. }\end{array}$ & $\begin{array}{l}\text { Treatment discontinuation: break of therapy } \\
\text { for more than } 150 \% \text { of the previous } \\
\text { days' supply. }\end{array}$ & $n=1[79]$ \\
\hline $\mathrm{RDD} / \mathrm{PDD}$ ratio & General & $\begin{array}{l}\text { Ratio between received daily dose } \\
\text { (corresponds to } \\
\text { the ratio between total doses received and } \\
\text { treatment days) and prescribed daily dose } \\
\text { (stands for the intention to treat and the real } \\
\text { prescriptive tendency). }\end{array}$ & $\begin{array}{l}\text { Adherence is assessed and given only as } \\
\text { an RDD/PDD ratio; there is no evaluation of } \\
\text { what is considered high or low adherence. }\end{array}$ & $n=1[92]$ \\
\hline
\end{tabular}




\subsection{Adherence Outcome}

All studies had one or more groups that received more pills than their control groups (Table A2, Appendix B). Those groups could be either a cohort of the same group or a comparison between two different groups. In most cases, the control group was a group of patients on the usual therapy (multiple pills). The test subjects received exactly the same active ingredients as the control group, but in a single formulation $[31-33,35,41-43,54,59,61,67,69,70,73,81,85,89]$; alternatively, the test group and the control group were not necessarily receiving the same drugs, but they simply had a different pill burden $[5,30,34,36-40,44-53,55-58,60,62,64-66,68,71,72,74-80,82-84,86-88,90-95]$.

The main interest of this review is how the pill burden is associated with patient adherence. In 56 out of 67 studies ( $84 \%)$, there was a significant difference in adherence between the test and control group (Table 5). In seven studies (10\%), the difference between both groups was insignificant. In only two studies (3\%), both opposite outcomes (improved and decreased adherence in the test group, depending on the treatment situation before the study index date) were reported [61,80]. See Table 5 for a summary of the outcomes.

Table 5. Summary of the study results per disease. Statistically significant differences in adherence outcomes are presented and considered.

\begin{tabular}{ccc}
\hline Disease & $\begin{array}{c}\text { Comparison of Adherence Outcome between } \\
\text { FDCT and MPT; Number of Studies with } \\
\text { Certain Result Is Given in Parenthesis }\end{array}$ & References \\
CVD & FDCT $>$ MPT $(n=9)$ & {$[58]$} \\
$(n=11)$ & FDCT $=$ MPT $(n=1)$ & {$[61]$} \\
Inconclusive * $(n=1)$ & {$[35,45,48,49,52,59,60,62,63]$} \\
HT & FDCT $>$ MPT $(n=28)$ & {$[80]$} \\
$(n=31)$ & FDCT $=\operatorname{MPT}(n=2)$ & {$[5,33,38-42,46,53,55,56,64-74,77-79,81-83]$} \\
DMII & Inconclusive * $(n=1)$ & {$[31,32,36,44,51,54,84-86]$} \\
$(n=10)$ & FDCT $>$ MPT $(n=9)$ & {$[30,37,57,87-89,91-94]$} \\
HIV $(n=14)$ & Inconclusive * $(n=1)$ & {$[34,50,90]$} \\
& FDCT $>\operatorname{MPT}(n=10)$ & {$[47]$} \\
\hline Other $(n=1)$ & FDCT $=\operatorname{MPT}(n=3)$ & {$[95]$} \\
\hline
\end{tabular}

* Several outcomes were observed (FDCT $<$ MPT or FDCT $>$ MPT or FDCT = MPT). See Table A2 (Appendix B) and Table A3 (Appendix C) for additional information. FDCT, fixed-dose combination therapy; MPT, multipill therapy; CVD, cardiovascular disease; DMII, diabetes mellitus type 2; LUTS/BHP, Lower urinary tract symptoms associated with benign prostatic hyperplasia; HIV, human immunodeficiency virus.

\subsection{Quality Assessment of the Included Studies}

Figure 3 shows the risk of bias summary for all seven randomized controlled trials $[35,45,48$, $52,59,75,88]$. As previously noted, blinding of participants was impossible due to the nature of the intervention, that is, different pill burden, resulting in high risk of performance bias in all studies. Thus, it was decided to be omitted from the overall risk of bias assessment. Based on the previously determined criteria, two RCTs reached standards for having an overall low risk of bias [48,52], two studies reached standards for having a medium risk of bias [35,59], and three studies were considered as having a high overall risk of bias $[45,75,88]$. 


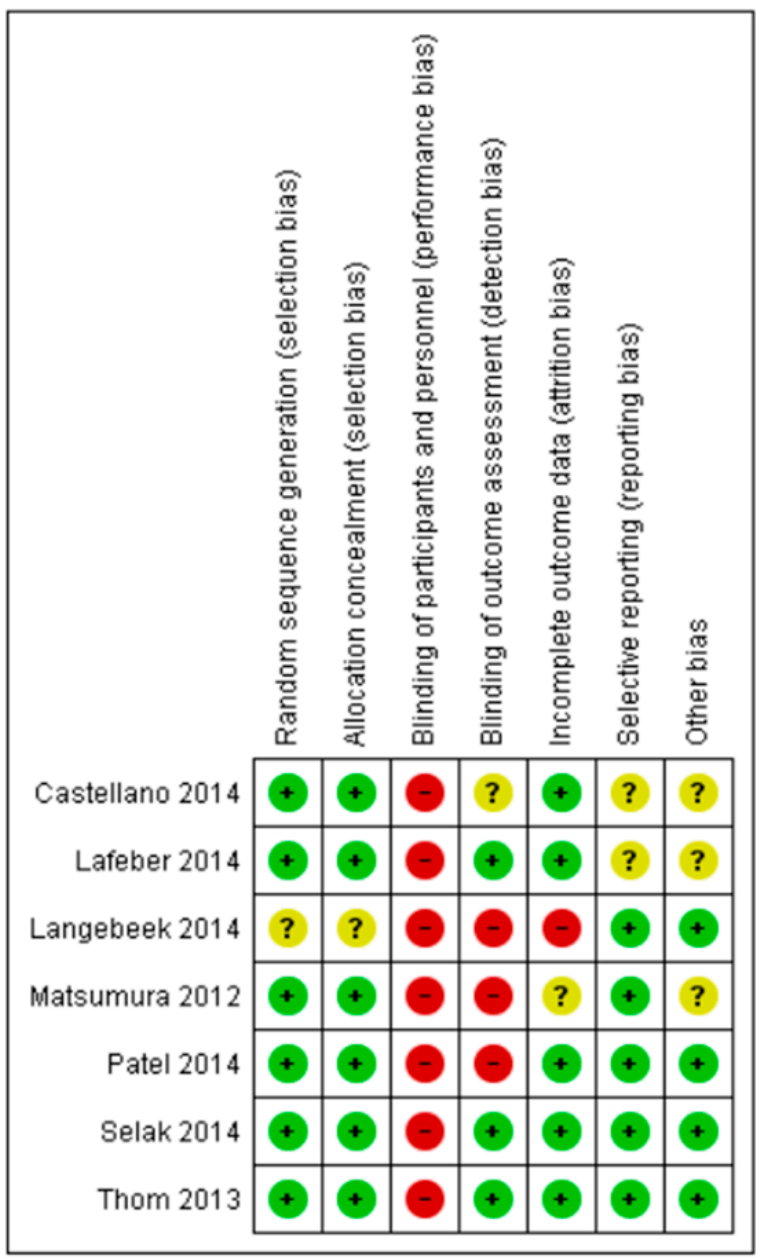

Figure 3. Results of risk of bias assessment for all randomized controlled trials (RCTs). Green: low risk of bias; red: high risk of bias; yellow: unclear risk of bias.

Except for Matsumura et al. [75], which reported on the insignificant difference in adherence between polypills and multipill therapy and which was assessed as having a high risk of bias, all the other RCTs $(n=6,86 \%)$ showed improved adherence when using polypills compared to multipill therapy.

From 60 of the included observational studies, $39(65 \%)$ were assigned eight or nine stars according to the Newcastle-Ottawa rating and were, thus, considered as high-quality studies $[5,33,36$, $37,41-44,46,47,50,51,53-56,58,61-65,67,71,72,74,76,78-84,86,89-91,94]$. There were 19 studies (32\%) that reached criteria for medium quality (six or seven stars) [30-32,34,38-40,49,57,60,68-70,77,85,87,92,93,95], and only two studies (3\%) were considered poor quality, with both having five stars assigned $[66,73]$.

In 50 out of a total of 60 observational studies (83\%), adherence to the polypill was shown to be increased compared to multipill therapy. Of the high-quality studies, 31 out of 39 studies $(79 \%)$ also showed this outcome, which does not differ importantly from findings from the total number of observational studies. Moreover, the ratio of studies with an insignificant difference in adherence to polypill and multipill therapy is very similar for high- and medium-quality studies (4/39 or 10\% vs. $2 / 19$ or $11 \%$, respectively). For a visual representation showing the number of studies with a certain outcome concerning adherence per quality of cohort study, see Figure 4. 


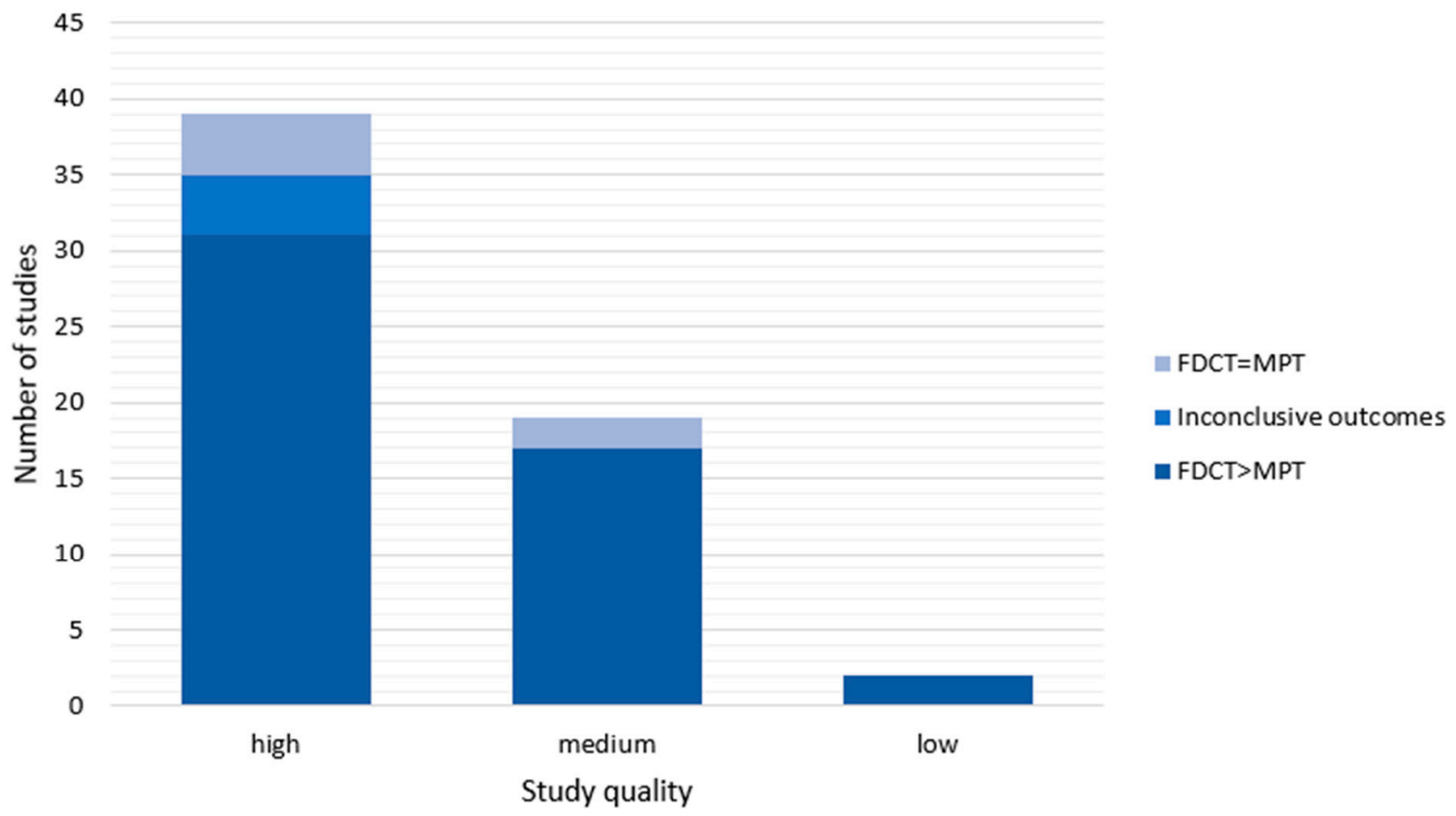

Figure 4. Number of studies with a certain outcome per study quality. FDCT, fixed-dose combination therapy; MPT, multipill therapy. Inconclusive outcomes: see Table 5, Table A2 (Appendix B), and Table A3 (Appendix C) for additional information.

\section{Discussion}

The main strength of our study is the broad range of included original peer-reviewed studies and that no restrictions concerning the medical condition, type of patients, or adherence measures were used in the research. Based on this systematic review, there is a connection between pill burden and medication adherence in medical conditions such as hypertension, diabetes mellitus type 2, cardiovascular diseases, and HIV. This is reflected by the fact that, in 56 out of 67 examined studies $(84 \%)$, patient adherence to single-pill fixed-dose combination therapy was significantly higher compared to free-dose combination therapy with multiple pills. Most of the 17 previously conducted meta-analyses and systematic reviews included in our research also suggested a positive effect of polypills on patient adherence. However, four out of 17 studies $(24 \%)$ did not reach the same conclusion; either the findings were inconclusive $[26,29]$ or FDCT was simply not shown to be superior to multipill therapy $[17,23]$. It has to be acknowledged, however, that the number of analyzed articles in these studies was either three [17,26], five [23], or six [29]; thus, they might not be highly representative.

Ten percent $(n=7)$ of the individual studies did not observe improved adherence in patients receiving polypill therapy $[34,50,58,75,76,90,95]$. The authors of these articles suggested the following methodological reasons for their results: (1) the number of participants was too small to obtain significant results [34]; (2) calculation of MPR was made alternatively and therapeutic or in-class switches were allowed for [58]; (3) the pill burden for some multipill therapy regimens was not high enough to have a significant influence on adherence [34]; (4) the study period was not long enough to detect differences between the polypill and multipill groups [75].

Interestingly, two out of 67 studies [61,80], dealing with CVD and HT, respectively, observed both positive and negative outcomes regarding the influence of FDCT on adherence. For the study, dealing with CVD [61], the article's authors suggested that the reasons for decreased adherence in patients taking polypills were adverse events. These were supposed to be falsely attributed to an active ingredient, which the patients in question were not receiving before the start of the study [61]. Authors of the other study dealing with HT, however, suggested a different reason for decreased adherence [80]. According to them, patients who were highly adherent to their previous treatment with free-combined antihypertensive drugs may not have been taking both of their antihypertensive medications at the 
same time and as prescribed. Hence, although they were switched to the equivalent FDC, their blood pressure lowered too much; therefore, they reduced the dose of FDCs on their own [80].

To our knowledge, no other previous systematic review in polypills and adherence covered as many original peer-reviewed studies and such a broad range of medical conditions as this. Our findings indicate that the rate at which polypill therapy is associated with higher adherence varies among medical conditions. In most of the studies on CVD, HT, and DMII therapies, adherence increased in patients with polypill therapy; however, in studies on HIV or LUTS therapies, no difference was observed in four out of 15 , that is, $27 \%$ of the studies. These differences in results can be partly explained by the methodological issues already discussed above. Further research on diseases other than CVD, HT, DMII, and HIV is needed to get a better understanding of whether and how the medical condition influences the impact of reduced pill burden on adherence.

The research mainly revolves around cardiovascular polypills; the reason for this is probably the abundance of patients suffering from CVD and HT [96]. Despite fewer studies on polypills for diabetes and HIV and one for lower urinary tract symptoms associated with benign prostatic hyperplasia, fixed-dose combination therapy was not introduced to other diseases in terms of its potential to influence adherence. As this literature review shows promising results for polypills with 56 out of 67 included studies improving adherence, the research could be extended to a wider range of medical conditions and a wider range of populations and health systems, as well as beyond high-income countries. The current research on polypills is dominated by the research conducted in the USA, reflecting their situation.

There are also some limitations concerning this systematic review. The first one is related to the methodological quality of the selected studies. The results would be more valid if more of the study designs were randomized controlled trials instead of retrospective and prospective cohort studies. Since the study design differed between articles, it was also not possible to assess study quality using only one universal method. Thus, two separate methods were used, one for randomized controlled trials [11] and the other for observational studies [12]. Consequently, it was not possible to make a joint summary of study quality assessment including all articles. Another limitation is related to the countries and the medications included in the studies. Specifically, every country has different public health concerns, as well as health systems, services, and finances, which influence medication practices. Since most of the reviewed studies were from high-income countries, particularly from the USA, a distorted image of the use of polypills in the rest of the world is possible. It must also be acknowledged that patient adherence is affected by many variables, such as patient age, medical condition, and clinical outcomes, which varied significantly in our selected articles. The assessment of these factors was not the aim of this review, but they could have significantly influenced our findings. Furthermore, due to the lack of articles regarding other diseases, it is not possible to conclude whether polypills are associated with an increase in medication adherence on a general level. This can become clear only when more studies regarding the effect of polypills on adherence in other diseases are conducted. Moreover, there is some overlapping among previously published systematic reviews and meta-analyses, as some articles were included in more than one of them, thereby giving those studies more emphasis.

Another issue that must be acknowledged as a possible limitation to our study is the diversity of methods for measuring adherence that were applied in the included studies. In 67 articles, 11 different adherence measures were used, which makes the results of the studies more difficult to compare, thereby adding a possible source of bias. The methods range, on the one hand, from assessing prescription claims and the number of the pills taken (indirect methods) to analyzing questionnaires and patient self-assessment, on the other hand (subjective methods) [75], all having specific advantages and limitations. For example, indirect methods are a very technical way of measuring adherence, but easy to apply to bigger datasets, which may explain their use in these studies. However, unlike self-assessment-based methods, they do not cover other aspects of a patient's life that also influence adherence. Additionally, pill-count and prescription claim analyses do not guarantee that the patients 
were taking the prescribed medicines $[40,49]$. On the other hand, self-assessment is a very subjective way of measuring adherence and is often prone to over-reporting the actual state $[45,87]$. In none of the studies were direct methods of measuring adherence used (i.e., measuring blood concentration of the active ingredients), which are the most objective methods, but also the most difficult, time-consuming, and expensive, as well as being inconvenient for patients [48]. In the future, it might be useful to consider the aspect of how patients perceive taking one instead of multiple pills in the methods for assessing adherence. Finally, due to such substantial heterogeneity between studies in terms of study design and reporting on the outcome, a pooled estimate of the effect of the pill burden on adherence was not analyzed, which can be considered as one of the limitations as well.

Another issue that emerged while carrying out this systematic review relates to the vague use of the terms "adherence" and "persistence." Certain methods (e.g., duration to treatment discontinuation) were defined as a measure of adherence in some of the studies, whereas the other studies stated it as a method of assessing therapy persistence. In the future, clearer definitions and distinction between these two terms and the methods used for measuring them should be made available to avoid misconceptions about the aims of the studies.

The years of publication of selected articles indicate that there was increased interest in polypills in the last years. Only seven of the selected articles (10\%) were published before 2008, and 35 out of a total of 67 studies (52\%) were published in the last six years. One of the reasons for this rising trend might be the fact that fixed-dose combination therapy shows promising results for improving patient adherence.

Most of today's commercially available polypills are intended for the treatment of only one indication. However, since it was already established how beneficial FDCT can be for patients, another interesting concept that is not yet applied very often, but is worth considering, is combining drugs for different indications into one formulation. Between 2010 and 2015, two FDCs composed of active pharmaceutical ingredients (APIs) for different comorbid diseases were already approved, both without full clinical study data [97]. In the future, more emphasis could be given to such FDCs, since that would reduce pill burden even more and, hopefully, have an even greater effect on patient adherence.

Even though this systematic review shows one of the potential benefits of polypill therapy, some of its disadvantages should also be acknowledged. For example, if dosing titration is needed, fixed-dose combination therapy can be inflexible if the appropriate dosage is not available in the form of a polypill [98-101]. That could lead to exposure of patients to unnecessary therapy and even adverse effects without added benefits [100]. Furthermore, if adverse effects occur, it cannot be possible for the patient to determine which of the components is causing them [101]. Another possible issue is that polypill therapy may be more expensive than multipill therapy $[66,67,98]$.

All in all, the evidence shown in this systematic review constitutes a base for possible advantages of polypill therapy over multipill therapy, at least in the investigated medical conditions, when tackling the widespread and alarming problem of patient adherence to medication. Thus, the role of polypills in clinical practice should not be neglected, even though their contribution to increasing adherence is only partial. There are many other patient- and system-related factors, such as patient age and socioeconomic status, health literacy, disease and medication beliefs, adverse effects, medical condition and its seriousness, treatment costs, and clinical outcomes, which also play a major role in achieving positive outcomes $[48,52,61,80,84]$. However, reducing the complexity of pill regimens, especially in diseases where the number of pills can seem overwhelming for patients, could at least partly lead to increased medication adherence and, therefore, also improved clinical outcomes. Nonetheless, to better understand the role of polypills in clinical practice, a higher number of long-term randomized controlled trials dealing with different medical conditions will be needed. 


\section{Conclusions}

This systematic review shows a connection between pill burden and medication adherence. In most of the included studies, adherence to polypill therapy was significantly higher compared to multipill therapy. Our findings indicate that the rate at which fixed-dose combination therapy is associated with higher adherence varies between medical conditions. As this systematic review shows promising results for polypills, research could be extended to a wider range of medical conditions, populations, and health systems, as well as beyond high-income countries.

Author Contributions: Conceptualization, M.A. and S.G.; methodology, A.B., K.D., and M.A.; formal analysis, A.B. and K.D.; investigation, A.B. and K.D.; writing-original draft preparation, A.B., K.D., and S.G.; writing-review and editing, A.B. and M.A.; visualization, A.B. and K.D.; supervision, M.A.; project administration, A.B. and M.A. All authors have read and agreed to the published version of the manuscript.

Funding: This research received no external funding.

Acknowledgments: We acknowledge Marika Pohjanoksa-Mäntylä, university lecturer at the University of Helsinki, Finland, for reviewing and commenting on the early version of the manuscript, and Igor Locatelli, university lecturer at the University of Ljubljana, Slovenia, for his help in the finalization stage of the manuscript.

Conflicts of Interest: The authors declare no conflict of interest. 


\section{Appendix A}

Table A1. Summary of the systematic reviews and meta-analyses $(n=17)$ regarding the medical condition in focus, study aim, number and design of included studies,

and main results.

\begin{tabular}{|c|c|c|c|c|}
\hline $\begin{array}{l}\text { Author, Reference, Year of } \\
\text { Publication, Study Design }\end{array}$ & $\begin{array}{l}\text { Medical Condition or } \\
\text { Disease in Focus }\end{array}$ & Study Aim & $\begin{array}{l}\text { Number and Design of } \\
\text { Studies Included }\end{array}$ & Main Results \\
\hline \multicolumn{5}{|c|}{ Various diseases $(n=1)$} \\
\hline $\begin{array}{l}\text { Van Galen et al. [29], } 2014 \\
\text { Systematic review and } \\
\text { meta-analysis }\end{array}$ & $\begin{array}{c}\operatorname{HIV}(n=2) \\
\text { tuberculosis }(n=3) \\
\text { hypertension }(n=1)\end{array}$ & $\begin{array}{l}\text { To summarize and synthesize existing } \\
\text { evidence from RCTs about the effect on } \\
\text { adherence to FDCT versus the same } \\
\text { drugs administered as separate pills }\end{array}$ & $6 \mathrm{RCTs}$ & $\begin{array}{l}\text { Administering drugs as FDC increased the } \\
\text { likelihood of optimal adherence (OR } 1.33 \\
(95 \% \text { CI, 1.03-1.71)); however, the difference } \\
\text { was statistically significant only for HIV. } \\
\text { Other diseases only showed the same trend. }\end{array}$ \\
\hline $\begin{array}{l}\text { Bangalore et al. [13], } 2007 \\
\text { Meta-analysis }\end{array}$ & $\begin{array}{l}\text { Tuberculosis }(n=2) \\
\text { hypertension }(n=4) \\
\text { DMII }(n=2) \\
\text { HIV }(n=1)\end{array}$ & $\begin{array}{l}\text { To evaluate the effect of FDCT on } \\
\text { patient adherence to medication }\end{array}$ & $\begin{array}{c}\text { 9: } 3 \text { RCTs, } 6 \text { retrospective } \\
\text { database analyses }\end{array}$ & $\begin{array}{l}\text { Utilizing FDC resulted in } 26 \% \text { decrease in the } \\
\text { risk of non-compliance compared to the } \\
\text { free-drug therapy (RR: } 0.74 ; 95 \% \text { CI: } \\
\qquad 0.69-0.80 ; p<0.0001)\end{array}$ \\
\hline \multicolumn{5}{|c|}{ Hypertension $(n=5)$} \\
\hline $\begin{array}{l}\text { Kawalec et al. [25], } 2018 \\
\text { Systematic review with } \\
\text { meta-analysis and narrative } \\
\text { synthesis }\end{array}$ & Hypertension & $\begin{array}{l}\text { To present an up-to-date evaluation of } \\
\text { the effectiveness of FDCs and free } \\
\text { equivalent combinations in } \\
\text { management of hypertension and to } \\
\text { get more accurate results by using } \\
\text { a stratified meta-analysis }\end{array}$ & $\begin{array}{l}\text { Whole systematic review: } \\
26 \text { clinical studies, } \\
2 \text { systematic reviews } \\
\text { Meta-analysis: } 12 ; \\
11 \text { retrospective cohort studies, } \\
1 \text { nonrandomized trial } \\
\text { (assessing adherence) }\end{array}$ & $\begin{array}{l}\text { FDC were shown to be associated with } \\
\text { an improvement in adherence in comparison } \\
\text { to free equivalent combination therapy; e.g., } \\
\text { meta-analysis of } 4 \text { cohort studies showed } \\
\text { an increased adherence with FDCT in the } \\
\text { average MPR by } 13.1 \%(95 \% \text { CIs: } \\
8.9 \%-17.2 \%, p<0.001) \text {. }\end{array}$ \\
\hline $\begin{array}{c}\text { Du et al. [14], } 2018 \\
\text { Meta-analysis }\end{array}$ & Hypertension & $\begin{array}{l}\text { To assess the effect of FDCT on } \\
\text { medication adherence in comparison to } \\
\text { free-equivalent combination therapies } \\
\text { in management of hypertension }\end{array}$ & $\begin{array}{l}7 \text { (assessing adherence): } \\
6 \text { retrospective studies, } \\
1 \text { prospective study }\end{array}$ & $\begin{array}{l}\text { FDCT was associated with higher medication } \\
\text { adherence than free equivalent combination } \\
\text { therapies; mean difference was } 14.92 \%(95 \% \\
\text { CIs: } 7.38 \%-22.46 \%) .\end{array}$ \\
\hline $\begin{array}{l}\text { Sherrill et al. [15], } 2011 \\
\text { Meta-analysis }\end{array}$ & Hypertension & $\begin{array}{l}\text { To compare healthcare resource use } \\
\text { costs, adherence, and persistence } \\
\text { between groups of patients on } \\
\text { single-pill and free-equivalent } \\
\text { combination therapies }\end{array}$ & $\begin{array}{l}7 \text { retrospective studies } \\
\text { (assessing adherence) }\end{array}$ & $\begin{array}{l}\text { The average MPR was } 8 \% \text { higher in the } \\
\text { patient group to prior antihypertensives and } \\
14 \% \text { higher in experienced FDCT patient } \\
\text { group, compared with corresponding } \\
\text { free-equivalent combination group. }\end{array}$ \\
\hline
\end{tabular}


Table A1. Cont.

\begin{tabular}{|c|c|c|c|c|}
\hline $\begin{array}{l}\text { Author, Reference, Year of } \\
\text { Publication, Study Design }\end{array}$ & $\begin{array}{l}\text { Medical Condition or } \\
\text { Disease in Focus }\end{array}$ & Study Aim & $\begin{array}{l}\text { Number and Design of } \\
\text { Studies Included }\end{array}$ & Main Results \\
\hline $\begin{array}{c}\text { Gupta et al. [16], } 2009 \\
\text { Meta-analysis }\end{array}$ & Hypertension & $\begin{array}{c}\text { To compare compliance, persistence, } \\
\text { blood pressure control, and safety } \\
\text { between FDCTs and free-drug } \\
\text { combinations }\end{array}$ & $\begin{array}{l}5 \text { (assessing adherence): } 2 \text { RCTs, } \\
3 \text { retrospective cohort studies }\end{array}$ & $\begin{array}{l}\text { The use of FDCT was associated with } \\
\text { significantly better compliance (OR: } 1.21,95 \% \\
\text { CIs: } 1.03-1.43 ; p=0.02) \text {. }\end{array}$ \\
\hline $\begin{array}{l}\text { Mallat et al. [26], } 2016 \\
\text { Systematic review and } \\
\text { meta-analysis }\end{array}$ & $\begin{array}{l}\text { Essential arterial } \\
\text { hypertension }\end{array}$ & $\begin{array}{l}\text { To compare the effects of FDCT and } \\
\text { free combination therapy with blood } \\
\text { pressure lowering agents in the } \\
\text { management of essential hypertension }\end{array}$ & 3 RCTs (assessing adherence) & $\begin{array}{c}\text { Two articles reported no difference in } \\
\text { adherence between groups, one article } \\
\text { showed increased adherence in FDCT group. }\end{array}$ \\
\hline \multicolumn{5}{|c|}{$\operatorname{CVD}(n=2)$} \\
\hline $\begin{array}{l}\text { Selak et al. [17], } 2018 \\
\text { Meta-analysis }\end{array}$ & CVD & $\begin{array}{l}\text { To assess the impact of FDCT on } \\
\text { achieving the 2016 European Society of } \\
\text { Cardiology guideline targets for blood } \\
\text { pressure, low-density lipoprotein, } \\
\text { cholesterol, and antiplatelet therapy }\end{array}$ & 3 RCTs & $\begin{array}{c}\text { No difference was observed between groups } \\
\text { in antiplatelet adherence ( } 96 \% \text { vs. } 96 \% \text {, } \\
\text { RR: } 1.00,95 \% \text { CIs: } 0.98-1.01) .\end{array}$ \\
\hline $\begin{array}{l}\text { Bahiru et al. [21], } 2017 \\
\text { Systematic review }\end{array}$ & Atherosclerotic CVD & $\begin{array}{l}\text { To study the effect of FDC therapy on } \\
\text { all-cause mortality, fatal and non-fatal } \\
\text { ASCVD events, adverse events, blood } \\
\text { pressure, lipids, adherence, } \\
\text { discontinuation rates, health-related } \\
\text { quality of life and costs }\end{array}$ & 4 RCTs (assessing adherence) & $\begin{array}{l}\text { FDC therapy improved adherence by } 44 \% \\
(26 \% \text { to } 65 \%) \text { compared with usual care. }\end{array}$ \\
\hline $\begin{array}{l}\text { Webster et al. [18], } 2016 \\
\text { Meta-analysis }\end{array}$ & CVD & $\begin{array}{l}\text { To compare FDCT with usual care in } \\
\text { patients with CVD or at high risk }\end{array}$ & 3 RCTs & $\begin{array}{l}\text { Participants in the FDC group had higher } \\
\text { adherence than patients with usual care } \\
(80 \% \text { vs. } 50 \% \text {, RR: } 1.58 ; 95 \% \text { CIs: } 1.32-1.90 \text {; } \\
\qquad p<0.001)\end{array}$ \\
\hline
\end{tabular}


Table A1. Cont.

\begin{tabular}{|c|c|c|c|c|}
\hline $\begin{array}{l}\text { Author, Reference, Year of } \\
\text { Publication, Study Design }\end{array}$ & $\begin{array}{l}\text { Medical Condition or } \\
\text { Disease in Focus }\end{array}$ & Study Aim & $\begin{array}{l}\text { Number and Design of } \\
\text { Studies Included }\end{array}$ & Main Results \\
\hline \multicolumn{5}{|c|}{ Diabetes $(n=2)$} \\
\hline $\begin{array}{l}\text { Han et al. [28], } 2012 \\
\text { Systematic review and } \\
\text { meta-analysis }\end{array}$ & DMII & $\begin{array}{l}\text { To compare effects of FDCs and dual } \\
\text { therapy of } \\
\text { antihyperglycemic agents on glycemic } \\
\text { control and adherence }\end{array}$ & $\begin{array}{l}8 \text { cohort studies } \\
\text { (assessing adherence) }\end{array}$ & $\begin{array}{l}\text { Five comparisons FDC versus dual therapy } \\
\text { cohorts showed significantly higher MPR } \\
\text { with FDC (MD = 8.6\% (95\% CIs: } 1.6-15.6) \\
p=0.0162) \text {. Three comparisons showed } \\
\text { results for patients who switched from dual } \\
\text { therapy to FDC or stayed on dual therapy, } \\
\text { with higher MPR for patients who switched } \\
\text { to FDC (MD = 5.0\% (95\% CIs: } 3.1-6.8) \\
p<<0.0001)\end{array}$ \\
\hline $\begin{array}{l}\text { Hutchins et al. [22], } 2011 \\
\text { Systematic review }\end{array}$ & DMII & $\begin{array}{l}\text { To evaluate adherence, patient-reported } \\
\text { outcomes, costs, resource use and cost } \\
\text { effectiveness between FDCT and LDCT }\end{array}$ & $\begin{array}{l}8 \text { cohort studies } \\
\text { (assessing adherence) }\end{array}$ & $\begin{array}{c}\text { Adherence was improved with using FDCT } \\
\text { instead of LDCT. }\end{array}$ \\
\hline \multicolumn{5}{|c|}{$\operatorname{HIV}(n=4)$} \\
\hline $\begin{array}{l}\text { Altice et al. [27], } 2019 \\
\text { Systematic review and } \\
\text { meta-analysis }\end{array}$ & HIV & $\begin{array}{l}\text { To study the relationship between } \\
\text { single or multiple tablet regimens and } \\
\text { treatment adherence and viral } \\
\text { suppression }\end{array}$ & $\begin{array}{l}\text { Whole systematic review: } \\
11 \text { prospective or retrospective } \\
\text { non-randomized studies } \\
\text { (assessing adherence); } \\
10 \text { full texts and one } \\
\text { conference abstract } \\
\text { Meta-analysis: } 8 ; 7 \text { full texts and } \\
\text { one conference abstract }\end{array}$ & $\begin{array}{l}\text { Polypills were associated with higher } \\
\text { treatment adherence than multipill therapy } \\
\text { in } 10 \text { studies: a } 63 \% \text { greater likelihood of } \\
\text { achieving } \geq 95 \% \text { adherence }(95 \% \text { CIs: } \\
\text { 1.52-1.74; } p<0.001 \text { ) and a } 43 \% \text { increase in the } \\
\text { likelihood of achieving } \geq 90 \% \text { adherence }(95 \% \\
\text { CIs: } 1.21-1.69 ; p<0.001) \text {. }\end{array}$ \\
\hline $\begin{array}{l}\text { Clay et al. [24], } 2018 \\
\text { Systematic review, } \\
\text { meta-analysis }\end{array}$ & HIV & $\begin{array}{l}\text { To compare single-pill to multi-tablet } \\
\text { regimens in HIV treatment by using } \\
\text { published data }\end{array}$ & $\begin{array}{l}\text { Reporting on adherence: } 30 \text {, } \\
\text { but only } 8 \text { observational studies } \\
\text { reported quantifiable data and } \\
\text { were included in the } \\
\text { meta-analysis. }\end{array}$ & $\begin{array}{l}\text { Patients utilizing single-pill regimens were } \\
\text { significantly more adherent (OR: } 1.96 \\
\qquad p<0.001)\end{array}$ \\
\hline
\end{tabular}


Table A1. Cont.

\begin{tabular}{|c|c|c|c|c|}
\hline $\begin{array}{l}\text { Author, Reference, Year of } \\
\text { Publication, Study Design }\end{array}$ & $\begin{array}{l}\text { Medical Condition or } \\
\text { Disease in Focus }\end{array}$ & Study Aim & $\begin{array}{l}\text { Number and Design of } \\
\text { Studies Included }\end{array}$ & Main Results \\
\hline $\begin{array}{l}\text { Clay et al. [20], } 2015 \\
\text { Meta-analysis }\end{array}$ & HIV & $\begin{array}{l}\text { To compare patient adherence and } \\
\text { clinical and economic outcomes of } \\
\text { FDCT and multipill therapy regimens }\end{array}$ & $\begin{array}{c}\text { Reporting on adherence: } 20 ; \\
\text { but only } 5 \text { having quantifiable } \\
\text { or analyzable data for } \\
\text { meta-analysis: } 4 \text { observational } \\
\text { studies, } 1 \text { economic } \\
\text { models-based study. }\end{array}$ & $\begin{array}{l}\text { Patients on FDCT were more adherent than } \\
\text { patients on multipill therapy regimen of any } \\
\text { frequency (OR: } 2.37,95 \% \text { CIs: } 1.68-3.35 ; \\
\qquad p<0.001 ; 4 \text { studies). }\end{array}$ \\
\hline $\begin{array}{c}\text { Ramjan et al. [19], } 2014 \\
\text { Meta-analysis }\end{array}$ & HIV & $\begin{array}{l}\text { To compare the advantages of FDC } \\
\text { antiretroviral therapy to separate pill } \\
\text { therapy regimens for patients } \\
\text { and programs }\end{array}$ & $\begin{array}{l}\text { Reporting on adherence: } 10 \text {, but } \\
\text { only } 7 \text { included in the } \\
\text { quantitative analysis: } 5 \text { RCTs } \\
\text { and } 2 \text { retrospective cohort } \\
\text { studies. }\end{array}$ & $\begin{array}{l}\text { RCTs showed better adherence in FDCT } \\
\text { group than in separate pill regimens } \\
\text { (RR: } 1.10,95 \% \text { CIs: } 0.98-1.22 \text { ); observational } \\
\text { studies showed the same trend (RR: } 1.17 \\
\text { 95\% CIs: } 1.07-1.28 \text { ). }\end{array}$ \\
\hline
\end{tabular}

Albanna et al. [23], 2013

Systematic review and meta-analysis
To assess different aspects of

Tuberculosis management of tuberculosis using or free combination treatment

FDCT, fixed-dose combination therapy; FDC, fixed-dose combination; RCT, randomized controlled trial; MPR, medication possession ratio; MD, mean difference; CVD, cardiovascular disease; ASCVD, atherosclerotic CVD; HIV, human immunodeficiency virus; DMII, diabetes mellitus type II; CI, confidence interval; OR, odds ratio; RR, relative risk. 


\section{Appendix B}

Table A2. Summary of the original articles $(n=67)$ regarding aim, study setting, follow-up period, population, type of adherence outcome measures, and results.

\begin{tabular}{cccc}
\hline $\begin{array}{c}\text { Author, Reference, Year of } \\
\text { Publication, Study Country, } \\
\text { Study Design }\end{array}$ & $\begin{array}{c}\text { Study Aim, Study Setting and } \\
\text { Follow-Up Period }\end{array}$ & Study Population & Outcome Measures \\
\hline & & $\operatorname{CVD}(n=11)$ & Main Results (Concerning Adherence)
\end{tabular}

Phase 1: to identify factors interfering

with adherence to $\mathrm{CV}$ medications for

secondary prevention after an acute

myocardial infarction.

Castellano et al. [35], 2014,

Argentina, Paraguay, Italy and Spain

Phase 1: observational, prospective, cross-sectional study Phase 2: randomized, controlled clinical trial

Phase 2: to test the impact of a polypill on adherence, blood pressure, low-density lipoprotein cholesterol, safety and tolerability.

Phase 1: 64 outpatient clinics in

Argentina, Brazil, Paraguay, Italy and Spain

Phase 2: 63 clinics in Argentina, Paraguay, Italy and Spain

Follow-up period: 9 months

To compare the morning and evening administration of a cardiovascular polypill and to assess the effect of the polypill on

patients' clinical outcomes,

Lafeber et al. [59], 2014 the Netherlands

Randomized controlled trial to the separately administered

identically dosed drug

University Medical Center Utrecht

Follow-up period: 18 weeks
Phase 2: 695 infarct patients $\geq 40$ years of age with a history of acute myocardial infarction within the last 2 years ( 350 on FDC therapy and 345 on conventional multipill treatment)
Adherence was measured via Morisky Medication Adherence Scale and pill count.
Polypills showed a significantly higher adherence in comparison with multiple pills $(50.8 \%$ vs. $41 \%, p=0.019)$
78 patients with established atherosclerotic CVD and an indication for the use of cardiovascular medication (during the three treatment periods of 6 weeks, each was receiving every type of therapy regimen (polypill in the morning, polypill in the evening, and mutlipill therapy with individual drugs), but in different sequences)
According to digital adherence monitoring, adherence was 5.2\% (95\% CIs: $1.4 \%-9.1 \%$ ) higher when using the polypill in the morning and 5.3\% (95\%

Adherence was measured via microelectronic monitoring device and Morisky Medication Adherence Scale. CIs: $1.4 \%-9.1 \%$ ) higher when using the polypill in the evening compared to multipill therapy. Morisky scale recognized non-adherence in $4(5 \%)$ participants when using the polypill in the morning, in $6(8 \%)$ participants when using the polypill in the evening, and in $10(13 \%)$ participants when using the individual agents $(p=0.22)$. 
Table A2. Cont.

\begin{tabular}{|c|c|c|c|c|}
\hline $\begin{array}{l}\text { Author, Reference, Year of } \\
\text { Publication, Study Country, } \\
\text { Study Design }\end{array}$ & $\begin{array}{l}\text { Study Aim, Study Setting and } \\
\text { Follow-Up Period }\end{array}$ & Study Population & Outcome Measures & Main Results (Concerning Adherence) \\
\hline $\begin{array}{l}\text { Patel et al. [45], 2014, Australia } \\
\text { Randomized controlled trial }\end{array}$ & $\begin{array}{l}\text { To determine if polypills improve } \\
\text { adherence in high risk CVD patients } \\
33 \text { Australian health centers } \\
\text { Follow-up period: } 18 \text { months }\end{array}$ & $\begin{array}{l}623 \text { patients } \geq 18 \text { years of age } \\
\text { with high CVD risk ( } 311 \\
\text { allocated to polypill treatment } \\
\text { and } 312 \text { to } \\
\text { conventional treatment). }\end{array}$ & $\begin{array}{l}\text { Adherence was } \\
\text { measured via } \\
\text { self-reporting. }\end{array}$ & $\begin{array}{l}\text { Patients on the polypill therapy reported } \\
\text { an adherence rate of } 70.1 \% \text { at study end, } \\
\text { while people on usual care reported } \\
\text { a } 46.9 \% \text { adherence }(p<0.001) .\end{array}$ \\
\hline $\begin{array}{l}\text { Selak et al. [48], 2014, } \\
\text { New Zealand } \\
\text { Randomized controlled trial }\end{array}$ & $\begin{array}{l}\text { To investigate the impact of FDCT on } \\
\text { the adherence rate and risk factor } \\
\text { control in patients with high } \\
\text { cardiovascular risk } \\
54 \text { general practices all over } \\
\text { New Zealand } \\
\text { Follow-up period: } 12 \text { months }\end{array}$ & $\begin{array}{l}513 \text { patients aged } 18-79 \text { years at } \\
\text { high risk of CVD ( } 256 \text { allocated } \\
\text { to FDC and } 257 \text { to usual care). }\end{array}$ & $\begin{array}{l}\text { Adherence was } \\
\text { measured via } \\
\text { self-reporting. }\end{array}$ & $\begin{array}{l}\text { Adherence in patients receiving FDCT } \\
\text { was higher compared to the two-pill } \\
\text { treatment }(81 \% \text { vs. } 46 \%, p<0.001)\end{array}$ \\
\hline $\begin{array}{l}\text { Thom et al. [52], 2013, UK, India, } \\
\text { Ireland, the Netherlands } \\
\text { Randomized, open-label, } \\
\text { blinded-end-point clinical trial }\end{array}$ & $\begin{array}{l}\text { To assess the impact of a polypill in } \\
\text { comparison to usual care on } \\
\text { adherence patterns, systolic blood } \\
\text { pressure and low-density } \\
\text { lipoprotein cholesterol } \\
\text { Patient data obtained via databases, } \\
\text { hospitals and general practices in } \\
\text { India, England, Ireland, } \\
\text { and the Netherlands } \\
\text { Follow-up period: } 12 \text { months }\end{array}$ & $\begin{array}{l}2004 \text { patients } \geq 18 \text { years of age } \\
\text { with high cardiovascular risk, } \\
\text { defined as either established } \\
\text { CVD, or an estimated } 5 \text {-year } \\
\text { CVD risk of } 15 \% \text { or greater } \\
\text { (1002 allocated to FDC group } \\
\text { and } 1002 \text { to usual care) }\end{array}$ & $\begin{array}{l}\text { Adherence was } \\
\text { measured via } \\
\text { self-reporting. }\end{array}$ & $\begin{array}{l}\text { The FDCT group had significantly } \\
\text { improved adherence compared to the } \\
\text { usual care group ( } 88 \% \text { vs. } 65 \%, p<0.001) \text {. }\end{array}$ \\
\hline
\end{tabular}


Table A2. Cont.

\begin{tabular}{|c|c|c|c|c|}
\hline $\begin{array}{l}\text { Author, Reference, Year of } \\
\text { Publication, Study Country, } \\
\text { Study Design }\end{array}$ & $\begin{array}{l}\text { Study Aim, Study Setting and } \\
\text { Follow-Up Period }\end{array}$ & Study Population & Outcome Measures & Main Results (Concerning Adherence) \\
\hline $\begin{array}{c}\text { Schaffer et al. [61], 2017, Australia } \\
\text { Retrospective cohort study }\end{array}$ & $\begin{array}{c}\text { To compare adherence in patients } \\
\text { initiating amlodipine/atorvastatin } \\
\text { therapy as an FDC or free } \\
\text { combination and to identify } \\
\text { subgroups benefiting most } \\
\text { from FDCs } \\
\text { Data retrieved via Australian } \\
\text { Pharmaceutical Benefits Scheme } \\
\text { Follow-up period: } 24 \text { months }\end{array}$ & $\begin{array}{l}9430 \text { patients, who started their } \\
\text { therapy with study drugs either } \\
\text { as an FDC or in free } \\
\text { combination ( } 3996 \text { on FDC and } \\
5434 \text { on free } \\
\text { combination therapy). }\end{array}$ & $\begin{array}{l}\text { Adherence was } \\
\text { measured via PDC. }\end{array}$ & $\begin{array}{l}\text { Patients initiating on an FDC were more } \\
\text { likely to have near-perfect adherence } \\
\text { compared to those with the free } \\
\text { combination, if they were previously } \\
\text { statin adherent irrespective of amlodipine } \\
\text { dose (amlodipine } 5 \text { mg: OR = } 1.61 \text {, } \\
\text { 95\% CIs: } 1.38-1.87 \text {; amlodipine } 10 \text { mg: } \\
\text { OR = 2.39, 95\% CIs: } 1.63-3.51 \text { ), or if they } \\
\text { were previously statin nonadherent and } \\
\text { initiated on the FDC with 5-mg } \\
\text { amlodipine (OR = } 1.87,95 \% \text { CIs: } \\
\text { 1.50-2.32). However, statin-naive } \\
\text { initiating on FDCT with } 10-m g \\
\text { amlodipine were less likely to have } \\
\text { near-perfect adherence (OR = 0.60, 95\% } \\
\text { CIs: 0.41-0.88) and more likely to have } \\
\text { early nonadherence (OR = } 1.73, \\
\text { 95\% CIs: } 1.17-2.55 \text { ) compared with the } \\
\text { free combination. }\end{array}$ \\
\hline $\begin{array}{l}\text { Bartlett et al. [58], 2016, Australia } \\
\text { Retrospective cohort study }\end{array}$ & $\begin{array}{l}\text { To compare adherence and } \\
\text { persistence in patients who add } \\
\text { ezetimibe to statin therapy as } \\
\text { a separate pill combination or FDC } \\
\text { Data retrieved via Australian } \\
\text { Pharmaceutical Benefits Scheme } \\
\text { Follow-up period: } 6 \text { months }\end{array}$ & $\begin{array}{l}9391 \text { patients, who initiated } \\
\text { ezetimibe as separate pill or } \\
\text { ezetimibe in FDC ( } 3651 \text { on } \\
\text { multipill therapy and } 5740 \text { on } \\
\text { FDC therapy). }\end{array}$ & $\begin{array}{l}\text { Adherence was } \\
\text { measured via MPR. }\end{array}$ & $\begin{array}{c}\text { Adherence was similar in both groups; } \\
\text { mean MPRs: multipill therapy }=0.99 \\
\text { (95\% CIs: 0.98-1.01) and FDC }=0.97 \\
\text { (95\% CIs: 0.95-0.99). }\end{array}$ \\
\hline
\end{tabular}


Table A2. Cont.

\begin{tabular}{|c|c|c|c|c|}
\hline $\begin{array}{l}\text { Author, Reference, Year of } \\
\text { Publication, Study Country, } \\
\text { Study Design }\end{array}$ & $\begin{array}{l}\text { Study Aim, Study Setting and } \\
\text { Follow-Up Period }\end{array}$ & Study Population & Outcome Measures & Main Results (Concerning Adherence) \\
\hline $\begin{array}{l}\text { Kamat et al. [63], 2011, USA } \\
\text { Retrospective cohort study }\end{array}$ & $\begin{array}{l}\text { To compare adherence between } \\
\text { single- and multipill therapies with } \\
\text { lipid-modifying drugs } \\
\text { Data retrieved via HealthCore } \\
\text { Integrated Research Database } \\
\text { Follow-up period: } 36 \text { months }\end{array}$ & $\begin{array}{l}42,460 \text { patients } \geq 18 \text { years of age } \\
\text { newly initiating FDC } \\
\text { dyslipidemia therapy } \\
\text { (38,847 patients) or equivalent } \\
\text { multipill therapy } \\
\text { (3613 patients). }\end{array}$ & $\begin{array}{l}\text { Adherence was } \\
\text { measured via MPR. }\end{array}$ & $\begin{array}{l}\text { The mean PDC was } 0.76( \pm 0.26) \text { and } 0.70 \\
( \pm 0.27) \text { in the first } 3 \text { months of treatment, } \\
0.54( \pm 0.40) \text { and } 0.45( \pm 0.40) \text { in the second } \\
3 \text { months of treatment, and } 0.50( \pm 0.41) \\
\text { and } 0.41 \text { ( } \pm 0.43) \text { for the remaining } 30 \\
\text { months for FDC and multipill groups, } \\
\text { respectively. Average PDC was } \\
\text { significantly higher in the SPC group } \\
(0.56 \pm 0.34) \text { than in the LDC group } \\
(0.47 \pm 0.33), p<0.0001 \text {. }\end{array}$ \\
\hline $\begin{array}{l}\text { Balu et al. [62], 2009, USA } \\
\text { Retrospective cohort study }\end{array}$ & $\begin{array}{l}\text { To compare adherence between } \\
\text { patients treated with the FDC } \\
\text { multipill combination therapy, to } \\
\text { assess the relationship between } \\
\text { optimal adherence and } \\
\text { CVD-associated total healthcare } \\
\text { resource utilization and } \\
\text { healthcare cost } \\
\text { Data retrieved via HealthCore } \\
\text { Integrated Research Database } \\
\text { Follow-up period: } 12 \text { months }\end{array}$ & $\begin{array}{l}8988 \text { patients } \geq 18 \text { years of age } \\
\text { newly initiating FDC (niacin } \\
\text { extended-release (NER) and } \\
\text { lovastatin (NERL); } 6638 \\
\text { patients) or multipill } \\
\text { combination therapies (NER } \\
\text { and simvastatin (NER/S); } 1687 \\
\text { patients, or lovastatin (NER/L); } \\
663 \text { patients) between } \\
\text { index dates. }\end{array}$ & $\begin{array}{l}\text { Adherence was } \\
\text { assessed via MPR. }\end{array}$ & $\begin{array}{l}\text { NER/S and NER/L patients were } 31.3 \% \\
\text { ( } 95 \% \text { CIs: } 22.9 \%-39.5 \%) \text { and } 39.1 \% \\
(95 \% \text { CIs: } 26.7 \%-49.4 \%) \text { less likely to be } \\
\text { adherent than NERL patients }(p<0.01) \text {. }\end{array}$ \\
\hline $\begin{array}{l}\text { LaFleur et al. [60], 2006, USA } \\
\text { Retrospective cohort study }\end{array}$ & $\begin{array}{l}\text { To compare patient adherence } \\
\text { between different pill regimen of } \\
\text { lipid-lowering drugs } \\
\text { Patient data retrieved from } \\
\text { RxAmerica database } \\
\text { Follow-up period: mean ca. } \\
12 \text { months }\end{array}$ & $\begin{array}{l}1672 \text { patients who started the } \\
\text { therapy with any of the study } \\
\text { drugs in the selection years } \\
\text { (among them, } 224 \text { in the ERNL } \\
\text { (= polypill) group and } 347 \text { in } \\
\text { the ERN-S (= combination } \\
\text { therapy) group. }\end{array}$ & $\begin{array}{c}\text { Adherence was } \\
\text { measured via MPR. }\end{array}$ & $\begin{array}{l}\text { Adherence rates for ERNL (= polypill) } \\
\text { and ERN-S (two pills) groups were } \\
\text { significantly different: } 72.5 \% \text { vs. } 75.8 \% \\
\qquad(p=0.033)\end{array}$ \\
\hline
\end{tabular}


Table A2. Cont.

\begin{tabular}{|c|c|c|c|c|}
\hline $\begin{array}{l}\text { Author, Reference, Year of } \\
\text { Publication, Study Country, } \\
\text { Study Design }\end{array}$ & $\begin{array}{l}\text { Study Aim, Study Setting and } \\
\text { Follow-Up Period }\end{array}$ & Study Population & Outcome Measures & Main Results (Concerning Adherence) \\
\hline $\begin{array}{l}\text { Taylor and Shoheiber [49], } \\
\text { 2003, USA } \\
\text { Retrospective cohort study }\end{array}$ & $\begin{array}{l}\text { To check if adherence is better for } \\
\text { a single-pill regimen vs. } \\
\text { a multiple-pill regimen. } \\
\text { Patient data retrieved from } \\
\text { a managed care organization that } \\
\text { provides benefits for members } \\
\text { enrolled in various health plans } \\
\text { Follow-up period: } 12 \text { months }\end{array}$ & $\begin{array}{l}5732 \text { patients aged } 18-64 \text { years } \\
\text { with a diagnosis code for HT } \\
\text { and who were treated with one } \\
\text { of the two study regimens and } \\
\text { filled at least two prescriptions } \\
\text { for their regimen on two } \\
\text { different dates during the study } \\
\text { period ( } 2754 \text { receiving FDC and } \\
2978 \text { receiving } \\
\text { multipill therapy). }\end{array}$ & $\begin{array}{c}\text { Adherence was } \\
\text { measured via MPR. }\end{array}$ & $\begin{array}{l}\text { The overall adherence rate in the polypill } \\
\text { group }(80.8 \%) \text { was significantly higher } \\
\text { than in the multipill group }(73.8 \%) \\
\qquad p<0.001 .\end{array}$ \\
\hline \multicolumn{5}{|c|}{ Hypertension $(n=31)$} \\
\hline $\begin{array}{l}\text { Matsumara et al. [75], 2012, Japan } \\
\text { Randomized controlled trial }\end{array}$ & $\begin{array}{l}\text { To investigate if medication } \\
\text { adherence in hypertensive patients } \\
\text { would improve with SPC } \\
29 \text { hospitals or clinics in Japan } \\
\text { Follow-up period: } 6 \text { months }\end{array}$ & $\begin{array}{l}207 \text { hypertensive patients } \\
\geq 20 \text { years of age (103 allocated } \\
\text { to FDC therapy and } 104 \text { to } \\
\text { multipill therapy). }\end{array}$ & $\begin{array}{l}\text { Adherence was } \\
\text { measured via residual } \\
\text { pill count. }\end{array}$ & $\begin{array}{l}\text { No significant differences were found in } \\
\text { adherence rate between SPC and } \\
\text { multiple-pill groups }(p=0.89) \text {. }\end{array}$ \\
\hline $\begin{array}{l}\text { Bramlage et al. [66], 2014, Austria, } \\
\text { Belgium, Germany, } \\
\text { the Netherlands, and Switzerland } \\
\text { Prospective, non-interventional } \\
\text { multicenter study }\end{array}$ & $\begin{array}{l}\text { To get information on safety, } \\
\text { tolerability and efficacy of the FDC of } \\
\text { olmesartan/amlodipine/hydrochlorothi } \\
\text { in daily practice and to check the } \\
\text { impact of polypills on adherence in } \\
\text { patients with HT } \\
\text { Primary care practice in five } \\
\text { European countries (Austria, } \\
\text { Belgium, Germany, the Netherlands, } \\
\text { and Switzerland) }\end{array}$ & $\begin{array}{c}14,979 \text { patients } \geq 18 \text { years of age } \\
\text { with essential HT and new } \\
\text { treatment with an FDC. }\end{array}$ & $\begin{array}{l}\text { Adherence was } \\
\text { measured via } \\
\text { a Morisky Medication } \\
\text { Adherence Scale. }\end{array}$ & $\begin{array}{l}\text { Mean adherence raised from } 6.0 \% \text { to } 6.9 \% \\
\text { when switching from multipill to FDCT } \\
\qquad(p<0.001) .\end{array}$ \\
\hline & Follow-up period: 6 months & & & \\
\hline
\end{tabular}


Table A2. Cont.

\begin{tabular}{|c|c|c|c|c|}
\hline $\begin{array}{l}\text { Author, Reference, Year of } \\
\text { Publication, Study Country, } \\
\text { Study Design }\end{array}$ & $\begin{array}{l}\text { Study Aim, Study Setting and } \\
\text { Follow-Up Period }\end{array}$ & Study Population & Outcome Measures & Main Results (Concerning Adherence) \\
\hline $\begin{array}{l}\text { Kumagai et al. [73], 2012, Japan } \\
\text { Prospective, multicenter, } \\
\text { observational study }\end{array}$ & $\begin{array}{l}\text { To investigate the impact of FDC } \\
\text { treatment on adherence, blood } \\
\text { pressure and healthcare costs } \\
\text { Several clinics and hospitals in Japan } \\
\text { Follow-up period: } 3 \text { months }\end{array}$ & $\begin{array}{c}196 \text { patients with hypertension } \\
\text { treated with free-drug } \\
\text { combinations of ARB and } \\
\text { amlodipine; free-drug } \\
\text { combinations were replaced } \\
\text { with the same dose of the FDC. }\end{array}$ & $\begin{array}{l}\text { Adherence was } \\
\text { measured via } \\
\text { self-reported } \\
\text { pill-count. }\end{array}$ & $\begin{array}{l}\text { Adherence was significantly improved } \\
\text { after switching from free combination to } \\
\text { FDC therapy }(p<0.01) \text {. }\end{array}$ \\
\hline $\begin{array}{l}\text { Ah et al. [64], 2019, Korea } \\
\text { Retrospective cohort study }\end{array}$ & $\begin{array}{l}\text { To compare adherence and } \\
\text { persistence between single-pill and } \\
\text { free equivalent combination and } \\
\text { between two single-pill combinations } \\
\text { as initial treatment hypertensive } \\
\text { patients who also received } \\
\text { prepackaged medications } \\
\text { from the pharmacy } \\
\text { Data retrieved via Korean national } \\
\text { claims database }\end{array}$ & $\begin{array}{l}40,350 \text { patients } \geq 18 \text { years of age } \\
\text { with ICD- } 10 \text { code of } \\
\text { hypertension and started on } \\
\text { combination regimen consisting } \\
\text { of an ARB and either a thiazide } \\
\text { diuretic or CCB ( } 20,175 \text { on } \\
\text { multipill therapy and } 20,175 \text { on } \\
\text { single-pill therapy). }\end{array}$ & $\begin{array}{l}\text { Adherence was } \\
\text { measured via MPR. }\end{array}$ & $\begin{array}{l}\text { The single-pill cohort had } 30 \% \text { higher } \\
\text { medication adherence (OR 1.31, } 95 \% \text { CIs: } \\
1.25-1.37) \text { than the free pill cohort } \\
\qquad(p<0.05) .\end{array}$ \\
\hline & Follow-up period: 12 months & & & \\
\hline
\end{tabular}


Table A2. Cont.

\begin{tabular}{|c|c|c|c|c|}
\hline $\begin{array}{l}\text { Author, Reference, Year of } \\
\text { Publication, Study Country, } \\
\text { Study Design }\end{array}$ & $\begin{array}{l}\text { Study Aim, Study Setting and } \\
\text { Follow-Up Period }\end{array}$ & Study Population & Outcome Measures & Main Results (Concerning Adherence) \\
\hline $\begin{array}{l}\text { Bramlage et al. [67], } \\
\text { 2018, Germany } \\
\text { Retrospective cohort study }\end{array}$ & $\begin{array}{l}\text { To assess the effect of FDCs on } \\
\text { persistence, adherence, } \\
\text { and medication costs, to acquire data } \\
\text { regarding the differences in patient } \\
\text { characteristics and comedications } \\
\text { between patients prescribed an FDC } \\
\text { and those prescribed a free-dose } \\
\text { combination, and to assess } \\
\text { motivations behind prescription of } \\
\text { one or another of the combination } \\
\text { therapy types } \\
\text { Data retrieved via IMS@Disease } \\
\text { Analyzer, which contains medical } \\
\text { records provided by } 2500 \text { physician } \\
\text { practices in Germany } \\
\text { Follow-up period: } 12 \text { months }\end{array}$ & $\begin{array}{l}\text { 81,958 hypertensive patients } \\
\text { who filled at least one } \\
\text { prescription for one of two } \\
\text { drugs combinations, either as } \\
\text { a single-pill FDC or as a two-pill } \\
\text { free-dose combination (10,938 } \\
\text { on ramipril/amlodipine FDCT, } \\
\text { 60,525 on ramipril/amlodipine } \\
\text { free dose therapy, } 1413 \text { on } \\
\text { candesartan/amlodipine FDCT, } \\
9082 \text { on candesartan/amlodipine } \\
\text { free dose therapy). }\end{array}$ & $\begin{array}{l}\text { Adherence was } \\
\text { assessed via MPR. }\end{array}$ & $\begin{array}{l}\text { The mean MPR was higher for patients } \\
\text { prescribed FDC compared to those taking } \\
\text { a free-dose combination } \\
\text { (ramipril/amlodipine: } 0.72 \text { vs. } 0.58 \\
p<0.001 \text {; candesartan/amlodipine: } \\
0.92 \text { vs. } 0.79, p<0.001 \text { ) }\end{array}$ \\
\hline $\begin{array}{l}\text { Degli Esposti et al. [69], 2018, Italy } \\
\text { Retrospective cohort study }\end{array}$ & $\begin{array}{c}\text { To assess the changes in treatment } \\
\text { adherence in patients who switched } \\
\text { from single-pill or two-pill therapy } \\
\text { to FDCT } \\
\text { Data retrieved via administrative } \\
\text { databases involving three local health } \\
\text { units in three Italian regions } \\
\text { Follow-up period: } 24 \text { months }\end{array}$ & $\begin{array}{l}24,020 \text { patients } \geq 18 \text { years of age } \\
\text { receiving at least one } \\
\text { prescription of selected } \\
\text { antihypertensive drugs in } \\
\text { selection period (1093 with } \\
\text { two-pill treatment, } 302 \text { switched } \\
\text { to FDCT, } 791 \text { did not; } 22,927 \\
\text { with MT, } 3295 \text { switched to } \\
\text { FDCT, 19,632 did not). }\end{array}$ & $\begin{array}{c}\text { Adherence was } \\
\text { measured via PDC. }\end{array}$ & $\begin{array}{l}\text { Adherence rose significantly among the } \\
\text { subjects who switched to FDC from } \\
\text { two-pill therapy }(+13 \%, p<0.001) \text {, while } \\
\text { it was almost unchanged or slightly } \\
\text { decreased among the subjects who did } \\
\operatorname{not}(-4 \%, p<0.001) \text {. }\end{array}$ \\
\hline
\end{tabular}


Table A2. Cont.

\begin{tabular}{|c|c|c|c|c|}
\hline $\begin{array}{l}\text { Author, Reference, Year of } \\
\text { Publication, Study Country, } \\
\text { Study Design }\end{array}$ & $\begin{array}{l}\text { Study Aim, Study Setting and } \\
\text { Follow-Up Period }\end{array}$ & Study Population & Outcome Measures & Main Results (Concerning Adherence) \\
\hline \multirow[t]{2}{*}{$\begin{array}{l}\text { Ho et al. [71], 2018, Taiwan } \\
\text { Retrospective cohort study }\end{array}$} & $\begin{array}{l}\text { To compare the clinical outcomes of } \\
\text { FDC vs. free combinations of } \\
\text { renin-angiotensin system inhibitor } \\
\text { and thiazide diuretic in } \\
\text { hypertension management } \\
\text { Data retrieved via National Health } \\
\text { Insurance Research Database } \\
\text { of Taiwan }\end{array}$ & $\begin{array}{l}17,568 \text { patients newly diagnosed } \\
\text { with hypertension aged } \geq 18 \\
\text { years who were prescribed with } \\
\text { FDC (13,176 patients) or free } \\
\text { combination }(4,392 \text { patients) of } \\
\text { renin-angiotensin system } \\
\text { inhibitors and thiazide diuretic. }\end{array}$ & \multirow[t]{2}{*}{$\begin{array}{l}\text { Adherence was } \\
\text { measured via PDC. }\end{array}$} & \multirow[t]{2}{*}{$\begin{array}{c}\text { FDC was associated with better } \\
\text { adherence (PDC } 58.01 \% \text { vs. } 46.96 \% \\
p<0.001 \text { ) than free combination therapy. }\end{array}$} \\
\hline & Follow-up period: at least 12 months & & & \\
\hline $\begin{array}{c}\text { Retrospective } \\
\text { cross-sectional study }\end{array}$ & $\begin{array}{l}\text { To assess the level of adherence to } \\
\text { antihypertensive treatment and } \\
\text { analyze how FDCT affects it } \\
\text { Family medicine practice in Tirgu } \\
\text { Mures, Romania } \\
\text { Follow-up period: } 48 \text { months }\end{array}$ & $\begin{array}{l}525 \text { patients } \geq 18 \text { years of age, } \\
\text { newly diagnosed with HT, who } \\
\text { started with therapy that } \\
\text { continued for at least } \\
3 \text { consecutive months ( } 90 \text { on } \\
\text { FDCT in the beginning, } \\
173 \text { in the end). }\end{array}$ & $\begin{array}{l}\text { Adherence was } \\
\text { measured via } \\
\text { prescription } \\
\text { records review. }\end{array}$ & $\begin{array}{c}\text { Interventions based on FDC during all } 4 \\
\text { years of study showed significantly } \\
\text { higher adherence compared to } \\
\text { interventions with single active } \\
\text { ingredients }(p=0.001)\end{array}$ \\
\hline \multirow[t]{2}{*}{$\begin{array}{c}\text { Verma et al. [79], 2018, Germany } \\
\text { Retrospective cohort study }\end{array}$} & $\begin{array}{l}\text { To compare clinical outcomes and } \\
\text { patient adherence with FDC therapy } \\
\text { and multipill therapy } \\
\text { Data retrieved via Ontario Drug } \\
\text { Benefit database }\end{array}$ & \multirow[t]{2}{*}{$\begin{array}{c}13,350 \text { patients } \geq 66 \text { years of age } \\
\text { who were new users of } \\
\text { antihypertensive therapy ( } 6675 \\
\text { on multipill therapy and } 6675 \\
\text { on FDCT). }\end{array}$} & \multirow[t]{2}{*}{$\begin{array}{l}\text { Adherence was } \\
\text { measured via the time } \\
\text { to the first instance of } \\
\text { discontinuation } \\
\text { and PDC. }\end{array}$} & \multirow[t]{2}{*}{$\begin{array}{l}\text { The median time to the first } \\
\text { discontinuation of therapy as well as the } \\
\text { PDC was higher in FDC group (191 days, } \\
70 \% \text { ) than in multipill group (150 days, } \\
42 \% ; p<0.01 \text { ). }\end{array}$} \\
\hline & Follow-up period: 5 years & & & \\
\hline
\end{tabular}


Table A2. Cont.

\begin{tabular}{|c|c|c|c|c|}
\hline $\begin{array}{c}\text { Author, Reference, Year of } \\
\text { Publication, Study Country, } \\
\text { Study Design }\end{array}$ & $\begin{array}{l}\text { Study Aim, Study Setting and } \\
\text { Follow-Up Period }\end{array}$ & Study Population & Outcome Measures & Main Results (Concerning Adherence) \\
\hline $\begin{array}{l}\text { Lauffenburger et al. [74], } \\
\text { 2017, USA } \\
\text { Retrospective cohort study }\end{array}$ & $\begin{array}{l}\text { To investigate patterns of } \\
\text { antihypertensive therapy initiation } \\
\text { and compare adherence and } \\
\text { persistence between patients } \\
\text { initiating FDC and single-pill } \\
\text { therapies } \\
\text { Data retrieved via a large national } \\
\text { health insurer } \\
\text { Follow-up period: } 12 \text { months }\end{array}$ & $\begin{array}{c}484,493 \text { patients } \geq 18 \text { years of } \\
\text { age, who initiated an oral } \\
\text { antihypertensive medication } \\
\text { therapy ( } 78,958 \text { on FDC, } 383,269 \\
\text { on single-pill therapy, } 22,266 \text { on } \\
\text { multipill therapy). }\end{array}$ & $\begin{array}{c}\text { Adherence was } \\
\text { measured via PDC. }\end{array}$ & $\begin{array}{l}\text { Patients with FDC therapy were } 13 \% \\
\text { more likely to be adherent than patients } \\
\text { on single-pill therapy (RR: } 1.13 ; 95 \% \text { CIs: } \\
1.11-1.14 ; p<0.05) \text {. }\end{array}$ \\
\hline \multirow[t]{2}{*}{$\begin{array}{l}\text { Tung et al. [53], 2017, Taiwan } \\
\text { Retrospective cohort study }\end{array}$} & $\begin{array}{c}\text { To compare the clinical outcomes of } \\
\text { FDCs and free combinations of ARB } \\
\text { and CCB in management of HT } \\
\text { Data retrieved via National Health } \\
\text { Insurance Research Database } \\
\text { of Taiwan }\end{array}$ & $\begin{array}{c}5680 \text { hypertensive patients } \geq 18 \\
\text { years of age, who were } \\
\text { prescribed an ARB and } \\
\text { a dihydropyridine CCB (1136 } \\
\text { on FDC therapy and } 4544 \text { on } \\
\text { free combination therapy). }\end{array}$ & $\begin{array}{c}\text { Adherence was } \\
\text { measured via PDC. }\end{array}$ & \multirow[t]{2}{*}{$\begin{array}{l}\text { Adherence was higher among patients } \\
\text { receiving an FDC compared with the free } \\
\text { combination group (PDC } \geq 80 \%: 64.97 \% \\
\text { vs. } 56.88 \% \text {; PDC from } 50 \% \text { to } 80 \% \text { : } \\
22.55 \% \text { vs. } 24.16 \% \text {; PDC }<50 \%: 12.48 \% \text { vs. } \\
18.95 \%(p<0.001)) \text {. }\end{array}$} \\
\hline & Follow-up period: 2.1 years (mean) & & & \\
\hline $\begin{array}{l}\text { Levi et al. [42], 2016, Italy } \\
\text { Retrospective cohort study }\end{array}$ & $\begin{array}{l}\text { Data retrieved via HS IMS Health } \\
\text { LPD, an Italian general } \\
\text { practice database } \\
\text { Follow-up period: } 6 \text { months }\end{array}$ & $\begin{array}{c}6612 \text { hypertensive patients } \geq 18 \\
\text { years of age, who were treated } \\
\text { with olmesartan/amlodipine as } \\
\text { an extemporaneous } \\
\text { combination or FDC ( } 2090 \text { on } \\
\text { extemporaneous combination } \\
\text { and } 4522 \text { on FDCs). }\end{array}$ & $\begin{array}{c}\text { Adherence was } \\
\text { measured via PDC. }\end{array}$ & $\begin{array}{l}55.1 \% \text { of the patients treated with FDC } \\
\text { were found to be highly adherent (PDC } \\
>80 \%) \text {, whereas, among patients treated } \\
\text { with the extemporaneous combination, } \\
\text { only } 15.9 \% \text { were highly adherent } \\
(p<0.001) .\end{array}$ \\
\hline
\end{tabular}


Table A2. Cont.

\begin{tabular}{|c|c|c|c|c|}
\hline $\begin{array}{l}\text { Author, Reference, Year of } \\
\text { Publication, Study Country, } \\
\text { Study Design }\end{array}$ & $\begin{array}{l}\text { Study Aim, Study Setting and } \\
\text { Follow-Up Period }\end{array}$ & Study Population & Outcome Measures & Main Results (Concerning Adherence) \\
\hline $\begin{array}{c}\text { Sonawane et al. [76], 2016, USA } \\
\text { Retrospective cohort study }\end{array}$ & $\begin{array}{l}\text { To compare the adherence of } \\
\text { alternative treatment modification } \\
\text { strategies and characterize the factors } \\
\text { associated with adherence after } \\
\text { such modifications } \\
\text { Data retrieved via BlueCross } \\
\text { BlueShield of Texas commercial } \\
\text { claims data } \\
\text { Follow-up period: } 12 \text { months }\end{array}$ & $\begin{array}{c}5998 \text { hypertensive patients aged } \\
\geq 18 \text { years who received } \\
\text { treatment modifications (1395 } \\
\text { on free-pill strategies and } 1207 \\
\text { on FDC therapy). }\end{array}$ & $\begin{array}{c}\text { Adherence was } \\
\text { measured via PDC. }\end{array}$ & $\begin{array}{l}\text { Adherence for FPC and FDC strategies } \\
\text { was } 0.67 \pm 0.25 \text { and } 0.69 \pm 0.29 \\
\text { respectively, which was not statistically } \\
\text { significant }(p<0.05)\end{array}$ \\
\hline $\begin{array}{l}\text { Hsu et al. [5], 2015, Taiwan } \\
\text { Retrospective cohort study }\end{array}$ & $\begin{array}{l}\text { To compare adherence and } \\
\text { persistence in hypertensive patients } \\
\text { on FDCT and LDCT among newly } \\
\text { diagnosed hypertensive patients } \\
\text { Patient data obtained from the } \\
\text { National Health Insurance Research } \\
\text { Database (NHIRD) } \\
\text { Follow-up period: } 24 \text { months }\end{array}$ & $\begin{array}{l}7348 \text { newly diagnosed HT } \\
\text { patients } \geq 20 \text { years of age ( } 5725 \\
\text { on FDC therapy and } 1623 \text { on } \\
\text { free combination therapy). }\end{array}$ & $\begin{array}{c}\text { Adherence was } \\
\text { measured via MPR. }\end{array}$ & $\begin{array}{l}\text { Adherence was higher for patients on } \\
\text { FDCT than patients on free dosing: } 66.6 \% \\
\text { vs. } 63.9 \% \text { after six months; } 52.6 \% \text { vs. } \\
46.7 \% \text { after one year; } 42.1 \% \text { vs. } 32.5 \% \\
\text { after two years (all } p<0.001 \text { ). }\end{array}$ \\
\hline $\begin{array}{c}\text { Machnicki et al. [82], 2015, USA } \\
\text { Retrospective cohort study }\end{array}$ & $\begin{array}{l}\text { To assess whether } \\
\text { amlodipine/valsartan/hydrochlorothiaz } \\
\text { SPC is associated with improved } \\
\text { adherence, persistence, and reduced } \\
\text { healthcare utilization and costs } \\
\text { compared to the FCT } \\
\text { Data retrieved using the Truven } \\
\text { MarketScan Commercial and } \\
\text { Medicare Supplemental Database } \\
\text { Follow-up period: } 12 \text { months }\end{array}$ & $\begin{array}{l}14,594 \text { hypertensive patients } \\
\geq 18 \text { years of age ( } 10,800 \text { in } \\
\text { single-pill group, } 3794 \text { in free } \\
\text { combination group). }\end{array}$ & $\begin{array}{l}\text { Adherence was } \\
\text { measured via PDC } \\
\text { and MPR. }\end{array}$ & $\begin{array}{c}\text { Patients on SPC exhibited higher } \\
\text { adherence according to MPR (85.7\% vs. } \\
77.0 \%) \text { and mean PDC (73.8\% vs. } 60.6 \%) \text {, } \\
\text { all } p<0.0001 .\end{array}$ \\
\hline
\end{tabular}


Table A2. Cont.

\begin{tabular}{|c|c|c|c|c|}
\hline $\begin{array}{c}\text { Author, Reference, Year of } \\
\text { Publication, Study Country, } \\
\text { Study Design }\end{array}$ & $\begin{array}{l}\text { Study Aim, Study Setting and } \\
\text { Follow-Up Period }\end{array}$ & Study Population & Outcome Measures & Main Results (Concerning Adherence) \\
\hline $\begin{array}{c}\text { Degli Esposti et al. [70], 2014, Italy } \\
\text { Retrospective cohort study }\end{array}$ & $\begin{array}{l}\text { To investigate the reasons for } \\
\text { prescribing polypills and the } \\
\text { influence of polypills on adherence in } \\
\text { hypertensive patients. } \\
\text { Three Italian local health units } \\
\text { (patient data retrieved via the } \\
\text { Medications Prescription Database) } \\
\text { Follow-up period: } 6 \text { months }\end{array}$ & $\begin{array}{c}21,008 \text { hypertensive patients } \\
\geq 18 \text { years of age with a } 6 \text {-month } \\
\text { history of receiving free } \\
\text { combination treatment ( } 2395 \\
\text { patients) or polypill treatment } \\
\text { (18,613 patients). }\end{array}$ & $\begin{array}{l}\text { Adherence was } \\
\text { measured via PDC. }\end{array}$ & $\begin{array}{l}\text { An increased percentage of patients who } \\
\text { switched to FDCT were adherent: }+24 \% \\
\text { when coming from a two-pill regime and } \\
+42 \% \text { when coming from single-pill } \\
\text { regime }(p<0.001) .\end{array}$ \\
\hline $\begin{array}{l}\text { Tung et al. [78], 2014, Taiwan } \\
\text { Retrospective cohort study }\end{array}$ & $\begin{array}{l}\text { To compare the clinical outcomes, } \\
\text { healthcare costs, persistence, } \\
\text { and adherence of HT treatment with } \\
\text { an FDC of amlodipine/valsartan and } \\
\text { free-drug combinations of ARB } \\
\text { and CCB } \\
\text { Data retrieved via the National } \\
\text { Health Insurance Research Database } \\
\text { (NHIRD) of Taiwan } \\
\text { Follow-up period: } 15 \text { months }\end{array}$ & $\begin{array}{c}16,505 \text { patients } \geq 18 \text { years of age } \\
\text { with the diagnosis of HT (13,204 } \\
\text { in FDC group FDC, } 3301 \text { in } \\
\text { combination therapy group). }\end{array}$ & $\begin{array}{l}\text { Adherence was } \\
\text { measured via PDC. }\end{array}$ & $\begin{array}{l}\text { The FDC group had a significantly higher } \\
\text { PDC than the combination therapy group } \\
(80.35 \% \text { vs. } 72.57 \%, p<0.001) .\end{array}$ \\
\hline $\begin{array}{l}\text { Wang et al. [80], 2014, Taiwan } \\
\text { Retrospective cohort study }\end{array}$ & $\begin{array}{l}\text { To assess the effect of single-pill } \\
\text { formulations on adherence in } \\
\text { hypertensive patients } \\
\text { Patient data retrieved from the } \\
\text { Taiwanese National Health } \\
\text { Insurance database } \\
\text { Follow-up period: } 12 \text { months }\end{array}$ & $\begin{array}{l}896 \text { patients who switched from } \\
\text { free pill combination therapy to } \\
\text { FDC therapy of the } \\
\text { same compound. }\end{array}$ & $\begin{array}{l}\text { Adherence was } \\
\text { measured via MPR. }\end{array}$ & $\begin{array}{l}\text { In patients with low or intermediate } \\
\text { preindex adherence }(n=729) \text {, switching } \\
\text { to SPCs resulted in improved MPR }(36 \% \\
\text { difference; } 95 \% \text { CIs: } 33 \%-39 \% ; p<0.001) \\
\text { However, patients with high preindex } \\
\text { adherence }(n=167) \text { switching to SPCs } \\
\text { resulted in a lower MPR }(-13 \% \text { difference } \\
\text { 95\% CIs: }-17 \% \text { to }-9 \% ; p<0.001) \text {. }\end{array}$ \\
\hline
\end{tabular}


Table A2. Cont.

\begin{tabular}{|c|c|c|c|c|}
\hline $\begin{array}{l}\text { Author, Reference, Year of } \\
\text { Publication, Study Country, } \\
\text { Study Design }\end{array}$ & $\begin{array}{l}\text { Study Aim, Study Setting and } \\
\text { Follow-Up Period }\end{array}$ & Study Population & Outcome Measures & Main Results (Concerning Adherence) \\
\hline $\begin{array}{l}\text { Xie et al. [81], 2014, USA } \\
\text { Retrospective cohort study }\end{array}$ & $\begin{array}{l}\text { To assess what the impact of the pill } \\
\text { burden is on adherence in } \\
\text { hypertensive patients } \\
\text { Data retrieved via health care claims } \\
\text { from the MarketScan Commercial } \\
\text { and Medicare Supplemental database } \\
\text { Follow-up period: } 12 \text { months }\end{array}$ & $\begin{array}{c}17,465 \text { hypertensive patients } \\
\geq 18 \text { years of age, who were } \\
\text { prescribed three } \\
\text { antihypertensive agents in the } \\
\text { form of single-, double- or } \\
\text { triple-pill regimens ( } 8516 \text { in } \\
\text { single-pill group, } 7842 \text { in } \\
\text { double-pill group, } 1107 \text { in } \\
\text { triple-pill group). }\end{array}$ & $\begin{array}{l}\text { Adherence was } \\
\text { measured via PDC. }\end{array}$ & $\begin{array}{l}\text { Patients in the double-pill cohort and } \\
\text { triple-pill cohort were } 55 \% \text { and } 74 \% \text {, } \\
\text { respectively, less likely to be adherent } \\
\text { than patients receiving only one pill } \\
\qquad(p<0.001)\end{array}$ \\
\hline \multirow[t]{2}{*}{$\begin{array}{l}\text { Panjabi et al. [83], 2013, USA } \\
\text { Retrospective cohort study }\end{array}$} & $\begin{array}{l}\text { To assess the impact of fixed- versus } \\
\text { loose-dose triple-combination } \\
\text { therapy on adherence, clinical, } \\
\text { and economic outcomes in patients } \\
\text { with hypertension } \\
\text { Data retrieved from a large US health } \\
\text { plan associated with OptumInsight }\end{array}$ & \multirow[t]{2}{*}{$\begin{array}{c}\text { 16,290 patients initiating triple } \\
\text { therapy with an ARB, ACEi, or } \\
\text { BB plus amlodipine and } \\
\text { hydrochlorothiazide (10,696 on } \\
\text { two-pill therapy (FDC + } \\
\text { a second pill) and } 5594 \text { on } \\
\text { a three separate pills therapy). }\end{array}$} & \multirow[t]{2}{*}{$\begin{array}{l}\text { Adherence was } \\
\text { assessed via PDC. }\end{array}$} & \multirow[t]{2}{*}{$\begin{array}{l}\text { Mean PDC was greater in patients } \\
\text { receiving two-pill therapy (ARB cohort: } \\
\text { three-pill }=0.41, \text { two-pill }=0.53 ; \text { ACEi } \\
\text { cohort: three-pill }=0.43, \text { two-pill }=0.50 \text {; } \\
\text { BB cohort: three-pill }=0.42, \\
\text { two-pill }=0.55 ; p<0.001) .\end{array}$} \\
\hline & Follow-up period: at least 12 months & & & \\
\hline $\begin{array}{l}\text { Baser et al. [65], 2011, USA } \\
\text { Retrospective cohort study }\end{array}$ & $\begin{array}{l}\text { To compare adherence of } \\
\text { valsartan/amlodipine SPC to } \\
\text { ARB/CCB multiple-pill } \\
\text { free combination } \\
\text { Data retrieved via US commercial } \\
\text { healthcare insurance claims } \\
\text { Follow-up period: } 12 \text { months }\end{array}$ & $\begin{array}{l}12,628 \text { hypertensive patients } \\
\geq 18 \text { years of age ( } 3259 \text { in } \\
\text { single-pill group, } 9369 \text { in free } \\
\text { combination group). }\end{array}$ & $\begin{array}{c}\text { Adherence was } \\
\text { measured via PDC. }\end{array}$ & $\begin{array}{l}\text { Patients on SPC were } 1.38 \text { times more } \\
\text { adherent to their therapy than multiple } \\
\text { pill users (95\% CIs: } 1.24-1.53 \text { ). }\end{array}$ \\
\hline
\end{tabular}


Table A2. Cont.

\begin{tabular}{|c|c|c|c|c|}
\hline $\begin{array}{l}\text { Author, Reference, Year of } \\
\text { Publication, Study Country, } \\
\text { Study Design }\end{array}$ & $\begin{array}{l}\text { Study Aim, Study Setting and } \\
\text { Follow-Up Period }\end{array}$ & Study Population & Outcome Measures & Main Results (Concerning Adherence) \\
\hline $\begin{array}{l}\text { Hussein et al. [72], 2010, USA } \\
\text { Retrospective cohort study }\end{array}$ & $\begin{array}{l}\text { To compare the adherence between } \\
\text { polypill and two-pill regimen of the } \\
\text { same drugs (statin + CCB) } \\
\text { Patient data obtained from the Health } \\
\text { Plan Claims (US) database } \\
\text { Follow-up period: } 6 \text { months }\end{array}$ & $\begin{array}{c}35,430 \text { patients } \geq 18 \text { years of age } \\
\text { with a pharmacy claim for } \\
\text { single-pill } \\
\text { amlodipine/atorvastatin or } \\
\text { claims for both a CCB and } \\
\text { a statin within any } 30 \text {-day } \\
\text { window in a selection year } \\
\text { (patients were categorized into } 4 \\
\text { cohorts according to use of CCB } \\
\text { and/or statin therapies before } \\
\text { the index date and within each } \\
\text { cohort based on receiving FDC } \\
\text { or multipill therapy). }\end{array}$ & $\begin{array}{c}\text { Adherence was } \\
\text { measured via PDC. }\end{array}$ & $\begin{array}{l}\text { Adherence rates were overall higher for } \\
\text { polypill groups and varied depending on } \\
\text { patients' previous treatment experiences. } \\
\text { The differences in adherence range from } \\
\text { no significant difference }(\mathrm{OR}=1.00) \text { in } \\
\text { naïve patients to significantly higher } \\
\text { adherence }(\mathrm{OR}=2.81, p<0.001) \text { in the } \\
\text { experienced cohort. }\end{array}$ \\
\hline $\begin{array}{l}\text { Yang et al. [55], 2010, USA } \\
\text { Retrospective cohort study }\end{array}$ & $\begin{array}{l}\text { To compare compliance, persistence, } \\
\text { health care resource utilization and } \\
\text { costs among hypertensive patients on } \\
\text { FDCT and LDCT } \\
\text { Data retrieved via Thomson Reuters } \\
\text { MarketScan Commercial and } \\
\text { Medicare Supplemental Databases } \\
\text { Follow-up period: } 6 \text { months }\end{array}$ & $\begin{array}{l}579,851 \text { patients } \geq 18 \text { years of } \\
\text { age initiating on either of the } \\
\text { selected FDC therapies (382,476 } \\
\text { patients) or the equivalent } \\
\text { free-pill therapies } \\
\text { (197,375 patients). }\end{array}$ & $\begin{array}{c}\text { Adherence was } \\
\text { measured via MPR. }\end{array}$ & $\begin{array}{l}\text { Patients receiving FDCT showed } \\
\text { significantly higher MPR than patients on } \\
\text { free-pill therapies }(72.8 \% \text { vs. } 61.3 \% ; 95 \% \\
\text { CI: } 11.4 \%, 11.7 \% ; p<0.05) .\end{array}$ \\
\hline $\begin{array}{l}\text { Zeng et al. [56], 2010, USA } \\
\text { Retrospective cohort study }\end{array}$ & $\begin{array}{c}\text { To assess adherence to ARB/CCB FDC } \\
\text { therapy compared with } \\
\text { free-pill combination } \\
\text { Data retrieved via MedImpact } \\
\text { Healthcare Systems database } \\
\text { Follow-up period: } 12 \text { months }\end{array}$ & $\begin{array}{l}4525 \text { hypertensive patients } \\
\geq 18 \text { years of age initiating on } \\
\text { either of selected FDC ( } 2213 \\
\text { patients) or free-pill therapies } \\
\text { (2312 patients). }\end{array}$ & $\begin{array}{c}\text { Adherence was } \\
\text { measured via PDC. }\end{array}$ & $\begin{array}{l}\text { Patients in the FDC group were } \\
\text { significantly more likely to adherent } \\
(\mathrm{OR}=1.90, p<0.001) \text { compared to } \\
\text { patients on free combination therapy. }\end{array}$ \\
\hline
\end{tabular}


Table A2. Cont.

\begin{tabular}{|c|c|c|c|c|}
\hline $\begin{array}{l}\text { Author, Reference, Year of } \\
\text { Publication, Study Country, } \\
\text { Study Design }\end{array}$ & $\begin{array}{l}\text { Study Aim, Study Setting and } \\
\text { Follow-Up Period }\end{array}$ & Study Population & Outcome Measures & Main Results (Concerning Adherence) \\
\hline $\begin{array}{l}\text { Chapman et al. [68], 2009, USA } \\
\text { Retrospective cohort study }\end{array}$ & $\begin{array}{l}\text { To compare the rate of adherence } \\
\text { between patients on one polypill and } \\
\text { patients with the same drugs in } \\
\text { separate pills } \\
\text { Data retrieved using PharMetrics } \\
\text { Patient-Centric Database } \\
\text { Follow-up period: } 6 \text { months }\end{array}$ & $\begin{array}{l}4556 \text { hypertensive patients } \\
\geq 18 \text { years of age prescribed } \\
\text { amlodipine who switched to } \\
\text { amlodipine/atorvastatin FDC } \\
\text { (1139 patients) or added a statin } \\
\text { to their amlodipine regimen } \\
\text { (3417 patients). }\end{array}$ & $\begin{array}{l}\text { Adherence was } \\
\text { measured via PDC. }\end{array}$ & $\begin{array}{l}\text { After } 180 \text { days, the follow-up showed } \\
\text { that patients on the polypill had a greater } \\
\text { improvement in adherence in } \\
\text { comparison to multiple pill cohort: } 50.8 \% \\
\text { vs. } 44.3 \%(p<0.001) \text {. }\end{array}$ \\
\hline $\begin{array}{l}\text { Hess et al. [41], 2009, USA } \\
\text { Retrospective cohort study }\end{array}$ & $\begin{array}{l}\text { To evaluate medication compliance, } \\
\text { persistence and hypertension-related } \\
\text { expenditures among patients that } \\
\text { switched from FDC to } \\
\text { free-combination therapy } \\
\text { Data obtained from the Thomson } \\
\text { Medstat MarketScan database } \\
\text { Follow-up period: } 12 \text { months }\end{array}$ & $\begin{array}{l}14,449 \text { patients ( } 7224 \text { switching } \\
\text { to free combination therapy and } \\
7225 \text { controls continuing their } \\
\text { FDC therapy) were enrolled. }\end{array}$ & $\begin{array}{l}\text { Adherence was } \\
\text { measured via MPR. }\end{array}$ & $\begin{array}{l}\text { Adherence among the patients } \\
\text { continuing on FDC therapy was } 22.1 \% \\
\text { higher }(p<0.001) \text { compared to the } \\
\text { patients who switched to free } \\
\text { combination therapy. }\end{array}$ \\
\hline $\begin{array}{l}\text { Brixner et al. [33], 2008, USA } \\
\text { Retrospective cohort study }\end{array}$ & $\begin{array}{c}\text { To compare the adherence, } \\
\text { persistence and medication costs } \\
\text { between single- and multipill drugs } \\
\text { Data retrieved via IHCIS National } \\
\text { Managed Care Benchmark Database } \\
\text { Follow-up period: } 12 \text { months }\end{array}$ & $\begin{array}{c}8711 \text { hypertensive patients } \geq 18 \\
\text { years of age, who were } \\
\text { prescribed study drugs in } \\
\text { combination and had at least } \\
110 \text { days of } \\
\text { recorded data during which no } \\
\text { other antihypertensive } \\
\text { medications were prescribed } \\
\text { before the start of therapy ( } 8510 \\
\text { in FDC group, } 561 \text { in } \\
\text { multipill group). }\end{array}$ & $\begin{array}{l}\text { Adherence was } \\
\text { measured via MPR. }\end{array}$ & $\begin{array}{l}\text { Adherence in patients receiving FDCT } \\
\text { was higher compared to the multipill } \\
\text { treatment: adherence rates were } 64.2 \% \\
\text { for FDCT and } 57.6 \% \text { for LDCT }(p<0.001) \text {. }\end{array}$ \\
\hline
\end{tabular}


Table A2. Cont.

\begin{tabular}{|c|c|c|c|c|}
\hline $\begin{array}{c}\text { Author, Reference, Year of } \\
\text { Publication, Study Country, } \\
\text { Study Design }\end{array}$ & $\begin{array}{l}\text { Study Aim, Study Setting and } \\
\text { Follow-Up Period }\end{array}$ & Study Population & Outcome Measures & Main Results (Concerning Adherence) \\
\hline $\begin{array}{l}\text { Dickson and Plauschinat [39], } \\
\text { 2008, USA } \\
\text { Retrospective cohort study }\end{array}$ & $\begin{array}{l}\text { To investigate the difference between } \\
\text { FDCs and separate drugs in } \\
\text { adherence and total costs } \\
\text { Patient data retrieved from South } \\
\text { Carolina Medicaid database } \\
\text { Follow-up period: } 12 \text { months }\end{array}$ & $\begin{array}{l}5704 \text { patients aged } 65-100 \text { years } \\
\text { who received at least two } \\
\text { prescriptions for study drugs in } \\
\text { one of the selection years ( } 2336 \\
\text { in FDC group and } 3368 \text { in free } \\
\text { combination group). }\end{array}$ & $\begin{array}{l}\text { Adherence was } \\
\text { measured via MPR. }\end{array}$ & $\begin{array}{l}\text { Adherence was significantly higher in } \\
\text { patients receiving FDCT than patients } \\
\text { receiving free-dose therapy: } 63.4 \% \text { vs. } \\
\qquad 49.0 \%(p<0.0001)\end{array}$ \\
\hline $\begin{array}{l}\text { Dickson and Plauschinat [38], } \\
\text { 2008, USA } \\
\text { Retrospective cohort study }\end{array}$ & $\begin{array}{l}\text { To assess adherence with } \\
\text { antihypertensive therapy among } \\
\text { African American and White } \\
\text { Medicaid patients receiving FDC or } \\
\text { free combination therapy } \\
\text { Patient data retrieved from the South } \\
\text { Carolina Medicaid database } \\
\text { Follow-up period: } 12 \text { months }\end{array}$ & $\begin{array}{l}4076 \text { patients aged } 18-100 \text { years } \\
\text { who received at least two } \\
\text { prescriptions for study drugs in } \\
\text { one of the selection years ( } 3363 \\
\text { in the FDC group and } 713 \text { in the } \\
\text { free combination group). }\end{array}$ & $\begin{array}{l}\text { Adherence was } \\
\text { measured via PDC. }\end{array}$ & $\begin{array}{l}\text { Adherence was significantly higher in } \\
\text { patients on FDCT compared to LDCT: } \\
\quad 58.6 \% \text { vs. } 48.1 \%(p<0.05)\end{array}$ \\
\hline $\begin{array}{l}\text { Patel et al. [46], 2008, USA } \\
\text { Retrospective cohort study }\end{array}$ & $\begin{array}{l}\text { To investigate if the adherence in } \\
\text { hypertensive patients is better with } \\
\text { an FDC than with multiple pills } \\
\text { Patient data retrieved from } \\
\text { MedImpact Healthcare Systems } \\
\text { Follow-up period: } 6 \text { months }\end{array}$ & $\begin{array}{c}4703 \text { patients } \geq 18 \text { years of age } \\
\text { who started a CCB or statin } \\
\text { treatment simultaneously or } \\
\text { within } 30 \text { days ( } 5 \text { cohorts, only } \\
\text { one ( } n=795 \text { ) receiving } \\
\text { polypill therapy). }\end{array}$ & $\begin{array}{l}\text { Adherence was } \\
\text { measured via PDC. }\end{array}$ & $\begin{array}{l}\text { After } 180 \text { days, the adherence rates of the } \\
\text { polypill group were } 9 \%-17 \% \text { higher than } \\
\text { those of other groups }(p<0.001) \\
\text { After one year, } 63.9 \% \text { of FDCT patients } \\
\text { were adherent, while only } 33.1 \%-43.6 \% \\
\text { were adherent in the group with the } \\
\text { separate pills ( } p<0.001 \text { ). }\end{array}$ \\
\hline
\end{tabular}


Table A2. Cont.

\begin{tabular}{|c|c|c|c|c|}
\hline $\begin{array}{c}\text { Author, Reference, Year of } \\
\text { Publication, Study Country, } \\
\text { Study Design }\end{array}$ & $\begin{array}{l}\text { Study Aim, Study Setting and } \\
\text { Follow-Up Period }\end{array}$ & Study Population & Outcome Measures & Main Results (Concerning Adherence) \\
\hline $\begin{array}{l}\text { Gerbino and Shoheiber [40], } \\
\text { 2007, Italy } \\
\text { Retrospective cohort study }\end{array}$ & $\begin{array}{l}\text { To check differences in adherence } \\
\text { patterns between an antihypertensive } \\
\text { polypill and the drugs } \\
\text { taken separately } \\
\text { Data retrieved via a pharmacy claims } \\
\text { database of a managed care } \\
\text { organization in the USA } \\
\text { Follow-up period: } 12 \text { months }\end{array}$ & $\begin{array}{l}6206 \text { hypertensive patients, who } \\
\text { received at least two } \\
\text { prescriptions for FDC or } \\
\text { double-pill therapy ( } 2839 \text { in } \\
\text { FDC group, } 3367 \text { in } \\
\text { double-pill group). }\end{array}$ & $\begin{array}{c}\text { Adherence was } \\
\text { measured via MPR. }\end{array}$ & $\begin{array}{l}\text { Adherence rates were significantly higher } \\
\text { in the FDCT group in comparison to the } \\
\text { double-pill group: } 87.9 \% \text { vs. } 69.2 \% \\
\qquad(p<0.0001) .\end{array}$ \\
\hline \multicolumn{5}{|c|}{ Diabetes $(n=10)$} \\
\hline $\begin{array}{l}\text { Rombopoulus et al. [85], } \\
\text { 2015, Greece } \\
\text { Prospective cohort study }\end{array}$ & $\begin{array}{l}\text { To evaluate the differences in the } \\
\text { adherence in DMII patients on FDC } \\
\text { and free-dose therapy of the } \\
\text { selected drugs } \\
\text { Multiple centers in Greece } \\
\text { Follow-up period: } 24 \text { weeks }\end{array}$ & $\begin{array}{l}659 \text { diabetic patients aged }>18 \\
\text { years with inadequate glycemic } \\
\text { control with metformin } \\
\text { monotherapy ( } 366 \text { on FDC and } \\
293 \text { on free-dose therapy). }\end{array}$ & $\begin{array}{l}\text { Adherence was } \\
\text { measured via } \\
\text { a questionnaire. }\end{array}$ & $\begin{array}{l}\text { In FDC group, } 98.9 \% \text { of patients were } \\
\text { compliant, compared to } 84.6 \% \text { in } \\
\text { free-dose group }(p<0.005) \text {. The odds } \\
\text { ratio for FDC vs. free-dose group was } \\
18.9 \text { ( } 95 \% \text { CIs: } 6.2-57.7 ; p<0.001)\end{array}$ \\
\hline $\begin{array}{l}\text { Lokhandwala et al. [86], } \\
\text { 2015, USA } \\
\text { Retrospective cohort study }\end{array}$ & $\begin{array}{l}\text { To compare persistence, adherence } \\
\text { and economic outcomes between } \\
\text { diabetic patients using FDC and } \\
\text { LDC products } \\
\text { Data retrieved via MarketScan } \\
\text { Commercial and Medicare } \\
\text { Supplemental Databases } \\
\text { Follow-up period: } 12 \text { months }\end{array}$ & $\begin{array}{l}23,361 \text { patients } \geq 18 \text { years of age } \\
\text { with DMII and one additional } \\
\text { oral anti-diabetic prescription of } \\
\text { the same regimen (FDC/LDC) as } \\
\text { the index prescription; } 12,590 \text { on } \\
\text { FDCT and } 10,771 \text { on LDCT. }\end{array}$ & $\begin{array}{l}\text { Adherence was } \\
\text { measured via MPR. }\end{array}$ & $\begin{array}{l}\text { FDC patients had significantly higher } \\
\text { rate of adherence than patients on LDCT } \\
(\mathrm{OR}=1.28 ; 95 \% \text { CIs: } 1.20-1.36 ; p<0.001) \text {. }\end{array}$ \\
\hline
\end{tabular}


Table A2. Cont.

\begin{tabular}{|c|c|c|c|c|}
\hline $\begin{array}{c}\text { Author, Reference, Year of } \\
\text { Publication, Study Country, } \\
\text { Study Design }\end{array}$ & $\begin{array}{l}\text { Study Aim, Study Setting and } \\
\text { Follow-Up Period }\end{array}$ & Study Population & Outcome Measures & Main Results (Concerning Adherence) \\
\hline $\begin{array}{l}\text { Vittorino Gaddi et al. [84], } \\
\text { 2013, Italy } \\
\text { Retrospective cohort study }\end{array}$ & $\begin{array}{l}\text { To evaluate antidiabetic drug } \\
\text { adherence between MT, LDCT, } \\
\text { and FDCT } \\
\text { Patient data obtained via the } \\
\text { ARNO database } \\
\text { Follow-up period: } 12 \text { months }\end{array}$ & $\begin{array}{l}\text { 169,375 diabetes patients with at } \\
\text { least one oral antidiabetic } \\
\text { prescription claim (91,816 in MT } \\
\text { group, 31,674 in FDCT group } \\
\text { and 19,573 in LDCT group; } \\
\text { 15.5\% were excluded due to } \\
\text { therapy switch in the } \\
\text { follow-up period). }\end{array}$ & $\begin{array}{l}\text { Adherence was } \\
\text { measured via MPR. }\end{array}$ & $\begin{array}{c}\text { Adherence rates were higher in the FDCT } \\
\text { group }(68.5 \%) \text { than in LDCT group } \\
(60.3 \%)(p<0.05) .\end{array}$ \\
\hline $\begin{array}{c}\text { Barner [31], 2011, USA } \\
\text { Retrospective cohort study }\end{array}$ & $\begin{array}{l}\text { To compare the adherence and costs } \\
\text { between MT, LDCT, and FDCT in the } \\
\text { treatment of DMII } \\
\text { Data retrieved via Texas Medicaid } \\
\text { prescription claims database } \\
\text { Follow-up period: at least } 12 \text { months }\end{array}$ & $\begin{array}{l}270 \text { patients aged } 18-65 \text { years } \\
\text { prescribed FDCT with } \\
\text { pioglitazone and metformin in } \\
\text { post index period and the } \\
\text { analogous LDCT or MT in pre } \\
\text { index period. }\end{array}$ & $\begin{array}{l}\text { Adherence was } \\
\text { measured via MPR. }\end{array}$ & $\begin{array}{l}\text { There was a significant increase in } \\
\text { adherence of } 8.9 \%(76.0 \% \text { to } 82.8 \%) \text { when } \\
\text { switching from LDCT to FDCT } \\
(p=0.0081) .\end{array}$ \\
\hline $\begin{array}{l}\text { Thayer et al. [51], 2010, USA } \\
\text { Retrospective cohort study }\end{array}$ & $\begin{array}{l}\text { To assess changes in adherence and } \\
\text { HbA1c in diabetes patients on } \\
\text { different drug regimes } \\
\text { Data obtained via two large databases } \\
\text { (not specified) } \\
\text { Follow-up period: at least } 6 \text { months }\end{array}$ & $\begin{array}{l}16,490 \text { patients } \geq 18 \text { years of age } \\
\text { with } 1 \text { or more prescription fills } \\
\text { for rosiglitazone, a sulfonylurea, } \\
\text { or rosiglitazone/glimepiride } \\
\text { FDCT during the identification } \\
\text { period (patients were grouped } \\
\text { according to baseline and } \\
\text { follow-up period treatment } \\
\text { plan; } 2518 \text { switched from mono } \\
\text { to dual therapy, } 543 \text { from MT to } \\
\text { FDCT, } 13,145 \text { remained on dual, } \\
284 \text { from dual to FDCT). }\end{array}$ & $\begin{array}{l}\text { Adherence was } \\
\text { measured via MPR. }\end{array}$ & $\begin{array}{l}\text { Switching from dual therapy to FDC } \\
\text { therapy showed a statistically significant } \\
\text { increase in adherence rate }(p<0.001) \text {. }\end{array}$ \\
\hline
\end{tabular}


Table A2. Cont.

\begin{tabular}{|c|c|c|c|c|}
\hline $\begin{array}{c}\text { Author, Reference, Year of } \\
\text { Publication, Study Country, } \\
\text { Study Design }\end{array}$ & $\begin{array}{l}\text { Study Aim, Study Setting and } \\
\text { Follow-Up Period }\end{array}$ & Study Population & Outcome Measures & Main Results (Concerning Adherence) \\
\hline $\begin{array}{l}\text { Cheong et al. [36], 2008, USA } \\
\text { Retrospective cohort study }\end{array}$ & $\begin{array}{l}\text { To check the influence of multiple } \\
\text { drug regimens (FDCT/dual therapy) } \\
\text { on patient adherence } \\
\text { Patient data retrieved via the Texas } \\
\text { Medicaid prescription } \\
\text { claims database } \\
\text { Follow-up period: } 12 \text { months }\end{array}$ & $\begin{array}{l}22,512 \text { patients aged } 22-89 \\
\text { years, who were prescribed } \\
\text { an oral antidiabetic FDCT or the } \\
\text { analogous dual therapy during } \\
\text { the identification period ( } 7750 \\
\text { FDCT users and } 14,762 \text { dual } \\
\text { therapy users). }\end{array}$ & $\begin{array}{l}\text { Adherence was } \\
\text { measured via MPR. }\end{array}$ & $\begin{array}{l}\text { Patients on FDCT had a higher MPR than } \\
\text { dual therapy users: } 78.6 \% \text { vs. } 77.2 \% \\
(p<0.001) \text {. Patients who switched from } \\
\text { dual therapy to FDCT saw an increase in } \\
\text { MPR of } 12.4 \% \text {, whereas people who } \\
\text { continued dual therapy only saw a rise of } \\
5.1 \%(p<0.001) \text {. }\end{array}$ \\
\hline $\begin{array}{l}\text { Pan et al. [44], 2008, USA } \\
\text { Retrospective cohort study }\end{array}$ & $\begin{array}{l}\text { To compare the patient adherence } \\
\text { between single-pill (FDCT) and } \\
\text { two-pill regimen } \\
\text { Patient data retrieved via the Medstat } \\
\text { MarketScan database } \\
\text { Follow-up period: } 6 \text { months }\end{array}$ & $\begin{array}{l}9170 \text { patients } \geq 18 \text { years of age } \\
\text { prescribed metformin or } \\
\text { sulfonylurea or both before July } \\
2000 \text { and both metformin and } \\
\text { sulfonylurea concurrently } \\
\text { (either separately or FDC) after } \\
\text { August } 2000 \text { ( } 2275 \text { FDC users } \\
\text { and } 6895 \text { non-FDC users). }\end{array}$ & $\begin{array}{l}\text { Adherence was } \\
\text { measured via MPR. }\end{array}$ & $\begin{array}{l}\text { The adherence to the FDCT in } \\
\text { comparison to the two-pill regimen was } \\
12.8 \% \text { higher }(p=\mathrm{NA}) \text {. }\end{array}$ \\
\hline $\begin{array}{l}\text { Vanderpoel et al. [54], 2005, USA } \\
\text { Retrospective cohort study }\end{array}$ & $\begin{array}{l}\text { To observe the changes in adherence } \\
\text { rates in patients switching from } \\
\text { mono- or dual therapy to a FDCT } \\
\text { Data retrieved via pharmacy } \\
\text { claims database } \\
\text { Follow-up period: } 6 \text { months }\end{array}$ & $\begin{array}{l}16,928 \text { patients } \geq 18 \text { years of age } \\
\text { with at least one pharmacy } \\
\text { claim for rosiglitazone or } \\
\text { metformin during the } \\
\text { identification period (patients } \\
\text { were grouped according to } \\
\text { treatment change from preindex } \\
\text { to postindex period; } 14,291 \\
\text { remained on mono therapy, } \\
1230 \text { on dual therapy, } 931 \\
\text { switched from mono to dual, } \\
349 \text { from mono to FDCT, } 127 \\
\text { from dual to FDCT). }\end{array}$ & $\begin{array}{l}\text { Adherence was } \\
\text { measured via MPR. }\end{array}$ & $\begin{array}{l}\text { A significant improvement has been } \\
\text { observed for patients switching from } \\
\text { dual therapy to FDCT }(3.5 \% \text { vs. }-1.3 \% \text {, } \\
\qquad p<0.005)\end{array}$ \\
\hline
\end{tabular}


Table A2. Cont.

\begin{tabular}{|c|c|c|c|c|}
\hline $\begin{array}{l}\text { Author, Reference, Year of } \\
\text { Publication, Study Country, } \\
\text { Study Design }\end{array}$ & $\begin{array}{l}\text { Study Aim, Study Setting and } \\
\text { Follow-Up Period }\end{array}$ & Study Population & Outcome Measures & Main Results (Concerning Adherence) \\
\hline $\begin{array}{l}\text { Blonde et al. [32], 2003, USA } \\
\text { Retrospective cohort study }\end{array}$ & $\begin{array}{l}\text { To check the impact of single-pill } \\
\text { drugs on HbA1c values and } \\
\text { adherence rates in DMII patients } \\
\text { Patient data retrieved via Medco } \\
\text { Health Solutions and } \\
\text { Quest Diagnostics } \\
\text { Follow-up period: } 6 \text { months }\end{array}$ & $\begin{array}{l}1421 \text { patients aged } 18-80 \text { years } \\
\text { who initiated single-pill or } \\
\text { multipill therapy and had A1C } \\
\text { measurements at baseline and } \\
\text { within } 76-194 \text { days of initiating } \\
\text { combination therapy ( } 471 \text { on } \\
\text { multipill therapy and } 950 \text { on } \\
\text { single-pill therapy). }\end{array}$ & $\begin{array}{c}\text { Adherence was } \\
\text { measured via MPR. }\end{array}$ & $\begin{array}{l}\text { Patients were more adherent to the } \\
\text { polypill in comparison to two-pill } \\
\text { regimen: } 84 \% \text { vs. } 76 \%(p<0.0001) \text {. }\end{array}$ \\
\hline $\begin{array}{l}\text { Melikian et al. [43], 2002, USA } \\
\text { Retrospective cohort study }\end{array}$ & $\begin{array}{l}\text { To investigate if adherence is different } \\
\text { in diabetes patients with different } \\
\text { drug regimens (FDCT, MT, } \\
\text { combination therapy) } \\
\text { Patient data obtained via pharmacy } \\
\text { claims from a pharmacy benefit and } \\
\text { medical-management company } \\
\text { Follow-up period: } 6 \text { months }\end{array}$ & $\begin{array}{l}6502 \text { patients } \geq 18 \text { years of age } \\
\text { who had an index pharmacy } \\
\text { claim for an oral antidiabetic } \\
\text { and were continuously enrolled } \\
\text { in the health plan ( } 4545 \\
\text { receiving metformin MT, } 1651 \\
\text { glyburide MT, } 219 \text { combination } \\
\text { therapy (59 of those switched to } \\
\text { FDCT), 87 FDCT). }\end{array}$ & $\begin{array}{c}\text { Adherence was } \\
\text { measured via MPR. }\end{array}$ & $\begin{array}{l}\text { For newly diagnosed diabetics, there was } \\
\text { no significant difference in adherence } \\
\text { between the therapies. } \\
\text { Patients switching from combination } \\
\text { therapy to FDCT (pill burden reduction) } \\
\text { showed a better adherence with FDCT: } \\
71 \% \text { vs. } 87 \%(p<0.001) \text {. }\end{array}$ \\
\hline \multicolumn{5}{|c|}{ HIV $(n=14)$} \\
\hline $\begin{array}{l}\text { Langebeek et al. [88], 2014, } \\
\text { the Netherlands, Belgium } \\
\text { Randomized controlled trial }\end{array}$ & $\begin{array}{l}\text { To investigate the effect of simplified } \\
\text { regimens ( } 1 \text { pill/multiple pills) on } \\
\text { adherence, life quality and } \\
\text { treatment satisfaction } \\
11 \text { different sites in Belgium and } \\
\text { the Netherlands } \\
\text { Follow-up period: } 24 \text { months }\end{array}$ & $\begin{array}{l}120 \mathrm{HIV} \text { patients (59 on } \\
\text { multipill therapy and } 61 \text { on } \\
\text { single-pill therapy). }\end{array}$ & $\begin{array}{c}\text { Adherence was } \\
\text { measured via } \\
\text { Simplified Medication } \\
\text { Adherence } \\
\text { Questionnaire. }\end{array}$ & $\begin{array}{l}\text { Single pill therapy resulted in better } \\
\text { adherence than multipill therapy } \\
\qquad(p=\mathrm{NA}) .\end{array}$ \\
\hline
\end{tabular}


Table A2. Cont.

\begin{tabular}{|c|c|c|c|c|}
\hline $\begin{array}{l}\text { Author, Reference, Year of } \\
\text { Publication, Study Country, } \\
\text { Study Design }\end{array}$ & $\begin{array}{l}\text { Study Aim, Study Setting and } \\
\text { Follow-Up Period }\end{array}$ & Study Population & Outcome Measures & Main Results (Concerning Adherence) \\
\hline $\begin{array}{l}\text { Arrabal-Duran et al. [90], } \\
\text { 2017, Spain } \\
\text { Observational prospective study }\end{array}$ & $\begin{array}{l}\text { To data on the effectiveness of } \\
\text { switching to an FDC regimen in HIV } \\
\text { patients with sustained } \\
\text { virological suppression } \\
\text { Gregorio Marañon University } \\
\text { Hospital, Madrid, Spain } \\
\text { Follow-up period: } 96 \text { weeks }\end{array}$ & $\begin{array}{l}57 \text { HIV patients whose previous } \\
\text { therapy was based on } \\
\text { twice-daily therapy regimen } \\
\text { and switched to the examined } \\
\text { FDC therapy. }\end{array}$ & $\begin{array}{l}\text { Adherence was } \\
\text { measured via PDC. }\end{array}$ & $\begin{array}{l}\text { The proportion of patients with } \\
\text { adherence }<90 \% \text { improved from } 15.5 \% \text { to } \\
10.4 \%(p=0.915) \text {, when they switched to } \\
\text { FDC therapy, but this difference is not } \\
\text { statistically significant. }\end{array}$ \\
\hline $\begin{array}{c}\text { Chen et al. [91], 2016, USA } \\
\text { Observational prospective study }\end{array}$ & $\begin{array}{l}\text { To study adherence barriers } \\
\text { associated with medication regimen } \\
\text { complexity and simplification } \\
\text { Patients in Atlanta, Georgia } \\
\text { Follow-up period: } 6 \text { weeks }\end{array}$ & $\begin{array}{l}750 \text { HIV patients aged } \geq 18 \text { years } \\
\text { receiving antiretroviral therapy } \\
\text { (166 patients on FDC, } 300 \text { taking } \\
\text { single-dose multipill regimen, } \\
284 \text { taking multi-dose } \\
\text { multipill regimen). }\end{array}$ & $\begin{array}{l}\text { Adherence was } \\
\text { measured via } \\
\text { pill count. }\end{array}$ & $\begin{array}{l}\text { A higher number of patients in polypill } \\
\text { group }(76 \%) \text { achieved } \geq 85 \% \text { adherence } \\
\text { compared to both the group taking } \\
\text { single-dose }(68 \%) \text { and the group taking } \\
\text { multi-dose multipill regimen }(66 \%) ; \\
\quad p<0.043 .\end{array}$ \\
\hline $\begin{array}{c}\text { Buscher et al. [34], 2012, USA } \\
\text { Prospective cohort study }\end{array}$ & $\begin{array}{l}\text { To study the impact of antiretroviral } \\
\text { therapy regimen on adherence in new } \\
\text { HIV patients (FDC vs. LDC and } \\
\text { once-daily vs. twice-daily dosing) } \\
\text { Houston, TX } \\
\text { Follow-up period: } 18 \text { months }\end{array}$ & $\begin{array}{l}99 \text { newly diagnosed HIV } \\
\text { patients ( } 34 \text { on FDCT, } 36 \text { on } \\
\text { once daily multipill regimen, } \\
29 \text { on twice daily regimen). }\end{array}$ & $\begin{array}{l}\text { Adherence was } \\
\text { measured via a } 30 \text {-day } \\
\text { VAS scale. }\end{array}$ & $\begin{array}{l}\text { No significant difference in adherence } \\
\text { was seen between the FDCT and LDCT } \\
\text { once-daily dosed group }(p=0.34) \text {. }\end{array}$ \\
\hline $\begin{array}{l}\text { Airoldi et al. [87], 2010, Italy } \\
\text { Prospective cohort study }\end{array}$ & $\begin{array}{l}\text { To check if there is a link between } \\
\text { a reduction in pill burden and } \\
\text { adherence in HIV patients } \\
6 \text { medical centers in Italy } \\
\text { Follow-up period: } 6 \text { months }\end{array}$ & $\begin{array}{l}212 \text { HIV patients who switched } \\
\text { from multipill to } \\
\text { single-pill therapy. }\end{array}$ & $\begin{array}{l}\text { Adherence was } \\
\text { measured via VAS. }\end{array}$ & $\begin{array}{l}\text { Adherence increased clinically } \\
\text { meaningfully for } 1.1 \%(p=0.01) \text {. }\end{array}$ \\
\hline
\end{tabular}


Table A2. Cont.

\begin{tabular}{|c|c|c|c|c|}
\hline $\begin{array}{l}\text { Author, Reference, Year of } \\
\text { Publication, Study Country, } \\
\text { Study Design }\end{array}$ & $\begin{array}{l}\text { Study Aim, Study Setting and } \\
\text { Follow-Up Period }\end{array}$ & Study Population & Outcome Measures & Main Results (Concerning Adherence) \\
\hline $\begin{array}{c}\text { Bangsberg et al. [30], 2010, USA } \\
\text { Prospective cohort study }\end{array}$ & $\begin{array}{l}\text { To check the influence of a decreased } \\
\text { pill burden on adherence in } \\
\text { HIV therapy } \\
\text { Data obtained via the REACH (The } \\
\text { Research on Access to Care in the } \\
\text { Homeless) cohort } \\
\text { Follow-up period: } 6 \text { months }\end{array}$ & $\begin{array}{l}118 \mathrm{HIV} \text { patients ( } 47 \text { on } \\
\text { single-pill therapy, } 57 \text { and } 14 \text { on } \\
\text { different multipill } \\
\text { therapies, respectively). }\end{array}$ & $\begin{array}{l}\text { Adherence was } \\
\text { measured via } \\
\text { unannounced } \\
\text { pill-count. }\end{array}$ & $\begin{array}{l}\text { Adherence was significantly greater for } \\
\text { polypills than for multiple pill users } \\
\qquad(p=0.006) .\end{array}$ \\
\hline $\begin{array}{l}\text { Santoleri et al. [92], 2018, Italy } \\
\text { Retrospective cohort study }\end{array}$ & $\begin{array}{l}\text { To compare adherence between } \\
\text { patients receiving single or multiple } \\
\text { tablet regimen antiretroviral therapy } \\
\text { Hospital Pharmacy of "Santo Spirito" } \\
\text { Hospital of Pescara, Italy } \\
\text { Follow-up period: } 5 \text { years }\end{array}$ & $\begin{array}{c}290 \text { patients who had } \\
\text { withdrawn from taking } \\
\text { antiretroviral drugs for at least } \\
6 \text { months in the } 5 \text {-year period } \\
\text { (66 on single pill and } 227 \text { on } \\
\text { multipill }(2,3,4 \text {, or } 5 \text { pills daily) } \\
\text { therapy). }\end{array}$ & $\begin{array}{l}\text { Adherence was } \\
\text { measured via } \\
\text { RDD/PDD ratio. }\end{array}$ & $\begin{array}{l}\text { Single pill therapy group had excellent } \\
\text { adherence value of } 0.98, \text { whereas } \\
\text { multiple pill therapy groups had lower } \\
\text { adherence levels of } 0.92-0.96 \text { during } \\
\text { years } 1-5 \text { of the study. }\end{array}$ \\
\hline $\begin{array}{l}\text { Yager et al. [94], 2017, USA } \\
\text { Retrospective cohort study }\end{array}$ & $\begin{array}{l}\text { To compare antiretroviral and } \\
\text { non-antiretroviral adherence between } \\
\text { single and multiple tablet regimens } \\
\text { Data retrieved via pharmacy refill } \\
\text { records (Upstate New York Veterans' } \\
\text { Healthcare Administration) } \\
\text { Follow-up period: } 1.1 \text { years for } \\
\text { multipill and } 2.3 \text { for } \\
\text { single-pill therapy }\end{array}$ & $\begin{array}{l}1202 \text { HIV patients } \geq 18 \text { years of } \\
\text { age on } \geq 3 \text { antiretroviral } \\
\text { medications for } \geq 3 \text { months and } \\
\text { available pharmacy refill } \\
\text { records (165 patients were on } \\
\text { single-pill, } 1037 \text { on multiple } \\
\text { tablet regimens). }\end{array}$ & $\begin{array}{c}\text { Adherence was } \\
\text { measured via MPR. }\end{array}$ & $\begin{array}{l}\text { Adherence was significantly higher for } \\
\text { single tablet regimens treatment-naïve } \\
\text { recipients }(80.8 \%-15.4 \%) \text { compared to the } \\
\text { multipill therapy }(65.9 \%-21.3 \%) \\
\qquad p<0.001 .\end{array}$ \\
\hline
\end{tabular}


Table A2. Cont.

\begin{tabular}{|c|c|c|c|c|}
\hline $\begin{array}{l}\text { Author, Reference, Year of } \\
\text { Publication, Study Country, } \\
\text { Study Design }\end{array}$ & $\begin{array}{l}\text { Study Aim, Study Setting and } \\
\text { Follow-Up Period }\end{array}$ & Study Population & Outcome Measures & Main Results (Concerning Adherence) \\
\hline $\begin{array}{l}\text { Sutton et al. [57], 2016, USA } \\
\text { Retrospective cohort study }\end{array}$ & $\begin{array}{l}\text { To evaluate the impact of } \\
\text { antiretroviral therapy as } \\
\text { a single-tablet regimen or } \\
\text { multiple-tablet regimen on outcomes } \\
\text { in HIV patients } \\
\text { Data retrieved via Veterans Health } \\
\text { Administration electronic health } \\
\text { record system } \\
\text { Follow-up period: at least } 60 \text { days }\end{array}$ & $\begin{array}{l}15,602 \text { patients to whom HIV } \\
\text { medications were dispensed as } \\
\text { single-tablet ( } 6191 \text { patients) or } \\
\text { multiple-tablet ( } 9411 \text { patients) } \\
\text { during the study period. }\end{array}$ & $\begin{array}{l}\text { Adherence was } \\
\text { measured via MPR. }\end{array}$ & $\begin{array}{l}\text { The odds of adherence were } \\
\text { approximately two times higher in } \\
\text { polypill group than in multiple therapy } \\
\text { group (OR, 2.16; 95\% CIs: 1.92-2.43; } \\
\qquad p<0.001 \text { ). }\end{array}$ \\
\hline $\begin{array}{l}\text { Sutton et al. [93], 2016, USA } \\
\text { Retrospective cohort study }\end{array}$ & $\begin{array}{l}\text { To assess the impact of pill burden in } \\
\text { HIV patients receiving single-tablet } \\
\text { or multi-tablet regimen on } \\
\text { clinical outcomes } \\
\text { Data retrieved via South Carolina } \\
\text { Medicaid medical and pharmacy } \\
\text { paid claims data } \\
\text { Follow-up period: at least } 60 \text { days }\end{array}$ & $\begin{array}{c}2174 \text { patients aged } \geq 18 \text { years } \\
\text { who were receiving a complete } \\
\text { antiretroviral single-tablet ( } 580 \\
\text { patients) or multiple-tablet } \\
\text { regimen (1594 patients) for at } \\
\text { least } 60 \text { days }\end{array}$ & $\begin{array}{l}\text { Adherence was } \\
\text { measured via PDC. }\end{array}$ & $\begin{array}{l}\text { Adherence was higher in single-pill than } \\
\text { in multiple-pill group ( } 80 \% \text { vs. } 67 \% \text {, } \\
\qquad p<0.0001) .\end{array}$ \\
\hline $\begin{array}{l}\text { Raffi et al. [47], 2015, France } \\
\text { Retrospective cohort study }\end{array}$ & $\begin{array}{l}\text { To compare adherence and } \\
\text { persistence in HIV adult patients } \\
\text { receiving combination ART (cART) as } \\
\text { a once-daily single-tablet regimen } \\
\text { versus other administration schedules } \\
\text { Data retrieved via French National } \\
\text { Healthcare Insurance Database } \\
\text { Follow-up period: mean } 32.8 \text { months }\end{array}$ & $\begin{array}{l}362 \text { patients } \geq 18 \text { years of age } \\
\text { receiving cART reimbursed in } \\
\text { selection years ( } 76 \text { on } \\
\text { single-tablet regimen, } 242 \\
\text { taking }>1 \text { pill once daily, } 248 \\
\text { having }>1 \text { daily intake). }\end{array}$ & $\begin{array}{l}\text { Adherence was } \\
\text { measured via } \\
\text { pill count. }\end{array}$ & $\begin{array}{l}\text { Better adherence was observed with the } \\
\text { polypill in comparison with regimens } \\
\text { with }>1 \text { daily intake but no difference } \\
\text { was observed in comparison with } \\
\text { regimens involving }>1 \text { pill once daily } \\
\text { (mean adherence } 89.6 \% \text { for the polypill, } \\
86.4 \% \text { for cART with }>1 \text { pill once daily } \\
\text { and } 77.0 \% \text { for cART with }>1 \text { daily intake } \\
(p<0.0001)) \text {. }\end{array}$ \\
\hline
\end{tabular}


Table A2. Cont.

\begin{tabular}{|c|c|c|c|c|}
\hline $\begin{array}{l}\text { Author, Reference, Year of } \\
\text { Publication, Study Country, } \\
\text { Study Design }\end{array}$ & $\begin{array}{l}\text { Study Aim, Study Setting and } \\
\text { Follow-Up Period }\end{array}$ & Study Population & Outcome Measures & Main Results (Concerning Adherence) \\
\hline $\begin{array}{l}\text { Tennant et al. [50], 2014, USA } \\
\text { Retrospective cohort study }\end{array}$ & $\begin{array}{l}\text { To compare adherence and virologic } \\
\text { outcomes in adult HIV patients on } \\
\text { single-tablet or multiple-tablet } \\
\text { antiretroviral therapy } \\
\text { Patients enrolled in AIDS Drug } \\
\text { Assistance Program at two } \\
\text { independent clinics in South Carolina } \\
\text { and Alabama } \\
\text { Follow-up period: mean } 22 \text { months } \\
\text { (multipill group) and } 14 \text { months } \\
\text { (single-pill group) }\end{array}$ & $\begin{array}{l}389 \text { HIV patients aged } \geq 18 \text { years } \\
\text { with a documented visit to one } \\
\text { of the two clinics and prescribed } \\
\text { one of the two examined } \\
\text { antiretroviral therapy regimens } \\
\text { (165 in single-tablet and } 224 \text { on } \\
\text { multipill therapy). }\end{array}$ & $\begin{array}{l}\text { Adherence was } \\
\text { assessed via MPR and } \\
\text { self-reporting. }\end{array}$ & $\begin{array}{l}\text { Median adherence rates were similar in } \\
\text { both groups, regardless of the way it was } \\
\text { assessed (based on clinic records: } 91 \% \\
\text { and } 93 \%(p<0.14) \text { in single-pill and } \\
\text { multipill group, respectively; } \\
\text { self-reporting: } 100 \% \text { and } 99 \%(p<0.05) \text { in } \\
\text { single-pill and multipill group, } \\
\text { respectively). However, the proportion of } \\
\text { adherent patients was higher in } \\
\text { single-pill therapy group; } 61.6 \% \text { vs. } \\
51.5 \% \text { ( } p=0.047 ; \text { based on clinic records) } \\
\text { and } 92.8 \% \text { vs. } 85.4 \% \text { ( } p=0.0179 ; \text { based on } \\
\text { self-reporting). }\end{array}$ \\
\hline $\begin{array}{l}\text { Cohen et al. [37], 2013, USA } \\
\text { Retrospective cohort study }\end{array}$ & $\begin{array}{l}\text { To compare adherence, healthcare } \\
\text { utilization and costs in antiretroviral } \\
\text { therapy with once-daily single-tablet } \\
\text { regimen to the therapy with two or } \\
\text { more pills per day } \\
\text { Data retrieved from the MarketScan } \\
\text { Medicaid Multi-State Database } \\
\text { Follow-up period: at least } 60 \text { days }\end{array}$ & $\begin{array}{l}7381 \text { patients (5584 taking two } \\
\text { or more pills per day and } 1797 \\
\text { on a single-pill therapy) with } \\
\text { an HIV diagnosis receiving } \\
\text { complete antiretroviral therapy. }\end{array}$ & $\begin{array}{l}\text { Adherence was } \\
\text { measured via MPR. }\end{array}$ & $\begin{array}{l}\text { Patients on single-tablet regimens were } \\
\text { significantly more likely to reach } 95 \% \\
\text { adherence }(p<0.01)\end{array}$ \\
\hline $\begin{array}{l}\text { Legoretta et al. [89], 2005, USA } \\
\text { Retrospective cohort study }\end{array}$ & $\begin{array}{l}\text { To investigate the influence of } \\
\text { pill-burden on adherence in } \\
\text { HIV-positive patients } \\
\text { Data obtained via } 2 \text { databases, West } \\
\text { Coast and Southeast state Medicaid } \\
\text { Follow-up period: at least } 2 \text { months }\end{array}$ & $\begin{array}{l}1427 \text { HIV patients } \geq 18 \text { years of } \\
\text { age, who were newly started on } \\
\text { antiretroviral therapy and had } \\
\text { at least one prescription refill in } \\
\text { the first } 60 \text { postindex days ( } 1363 \\
\text { on polypill therapy, } 64 \text { on } \\
\text { multipill therapy). }\end{array}$ & $\begin{array}{l}\text { Adherence was } \\
\text { measured via MPR. }\end{array}$ & $\begin{array}{l}\text { Mean adherence was } 85 \% \text { for polypills, } \\
\text { while it was significantly lower }(75 \%) \text { for } \\
\text { multiple pills therapy }(p<0.001) \text {. }\end{array}$ \\
\hline
\end{tabular}


Table A2. Cont.

\begin{tabular}{|c|c|c|c|c|}
\hline $\begin{array}{l}\text { Author, Reference, Year of } \\
\text { Publication, Study Country, } \\
\text { Study Design }\end{array}$ & $\begin{array}{l}\text { Study Aim, Study Setting and } \\
\text { Follow-Up Period }\end{array}$ & Study Population & Outcome Measures & Main Results (Concerning Adherence) \\
\hline \multicolumn{5}{|c|}{ LUTS/BHP $(n=1)$} \\
\hline $\begin{array}{l}\text { Drake et al. [95], 2017, } \\
\text { the Netherlands } \\
\text { Retrospective cohort study }\end{array}$ & $\begin{array}{l}\text { To compare treatment persistence and } \\
\text { adherence with } \alpha \text {-blocker plus } \\
\text { antimuscarinic combination therapy } \\
\text { in men with LUTS/BPH between } \\
\text { those prescribed an FDC and those on } \\
\text { multipill therapy } \\
\\
\text { Data retrieved via the Netherlands } \\
\text { IMS LifeLink }{ }^{\mathrm{TM}} \text { LRx database, which } \\
\text { contains data from pharmacies and } \\
\text { dispensing (general practices) in } \\
\text { the Netherlands } \\
\text { Follow-up period: } 12 \text { months }\end{array}$ & $\begin{array}{c}1891 \text { patients } \geq 45 \text { years of age, } \\
\text { who received combination } \\
\text { therapy with study drugs as } \\
\text { FDC or multipill therapy ( } 665 \\
\text { on FDC therapy and } 1,226 \text { on } \\
\text { multipill therapy). }\end{array}$ & $\begin{array}{l}\text { Adherence was } \\
\text { measured via MPR. }\end{array}$ & $\begin{array}{l}\text { Adherence was similar in both groups of } \\
\text { patients; } 80.0 \% \text { of the patients on FDC } \\
\text { therapy were adherent, while the } \\
\text { adherence among patients on } \alpha \text {-blocker } \\
\text { and antimuscarinic concomitant therapy } \\
\text { was } 85.8 \% \text { and } 75.2 \% \text {, respectively } \\
\qquad(p=\mathrm{NA}) .\end{array}$ \\
\hline
\end{tabular}




\section{Appendix C}

Table A3. General article information regarding disease, drugs, formulation, and outcomes.

\begin{tabular}{|c|c|c|c|}
\hline Condition, Reference & $\begin{array}{l}\text { Active Ingredients in the Polypill and } \\
\text { Free-Pill Combination }\end{array}$ & Dose (mg) & $\begin{array}{l}\text { Outcome on Adherence } \\
\text { (+: Improved with Using FDC; } \\
\text {-: Decreased with Using FDC; } \\
\text { 0: No Difference) }\end{array}$ \\
\hline CVD [35] & $\begin{array}{l}\text { FPC and FDC: acetylsalicylic } \\
\text { acid/simvastatin/ramipril }\end{array}$ & $100 \mathrm{mg} / 40 \mathrm{mg} / 2.5 \mathrm{mg}$ or $100 \mathrm{mg} / 40 \mathrm{mg} / 5 \mathrm{mg}$ or $100 \mathrm{mg} / 40 \mathrm{mg} / 10 \mathrm{mg}$ & + \\
\hline CVD [59] & $\begin{array}{c}\text { FPC and FDC: } \\
\text { aspirin/simvastatin/lisinopril/HCTZ }\end{array}$ & $75 \mathrm{mg} / 40 \mathrm{mg} / 10 \mathrm{mg} / 12.5 \mathrm{mg}$ & + \\
\hline CVD [45] & $\begin{array}{l}\text { FPC: various; FDC: } \\
\text { aspirin/simvastatin/lisinopril/either } \\
\text { atenolol or HCTZ }\end{array}$ & $75 \mathrm{mg} / 40 \mathrm{mg} / 10 \mathrm{mg} / 50 \mathrm{mg}$ (atenolol) or $12.5 \mathrm{mg}$ (HCTZ) & + \\
\hline CVD [48] & $\begin{array}{c}\text { FPC: various; FDC: } \\
\text { aspirin/simvastatin/lisinopril with either } \\
\text { atenolol or HCTZ }\end{array}$ & $75 \mathrm{mg} / 40 \mathrm{mg} / 10 \mathrm{mg} / 50 \mathrm{mg}$ (atenolol) or $12.5 \mathrm{mg}$ (HCTZ) & + \\
\hline CVD [52] & $\begin{array}{c}\text { FPC: various; FDC: } \\
\text { aspirin/simvastatin/lisinopril and either } \\
\text { atenolol or HCTZ }\end{array}$ & $75 \mathrm{mg} / 40 \mathrm{mg} / 10 \mathrm{mg} / 50 \mathrm{mg}$ (atenolol) or $12.5 \mathrm{mg}$ (HCTZ) & + \\
\hline CVD [61] & FPC and FDC: amlodipine/atorvastatin & $\begin{array}{l}\text { FPCs: amlodipine } 5 \text { and } 10 \mathrm{mg} \text {; atorvastatin } 10,20,40 \text {, and } 80 \mathrm{mg} \text {; } \\
\text { FDCs } 5 \mathrm{mg} / 10 \mathrm{mg} \text { or } 5 \mathrm{mg} / 20 \mathrm{mg} \text { or } 5 \mathrm{mg} / 40 \mathrm{mg} \text { or } 5 \mathrm{mg} / 80 \mathrm{mg} \text { or } \\
10 \mathrm{mg} / 10 \mathrm{mg} \text { or } 10 \mathrm{mg} / 20 \mathrm{mg} \text { or } 10 \mathrm{mg} / 40 \mathrm{mg} \text { or } 10 \mathrm{mg} / 80 \mathrm{mg}\end{array}$ & + or - \\
\hline Hyperlipidemia [58] & FPC and FDC: ezetimibe/statin & $10 \mathrm{mg} /$ varying dose (statin) & 0 \\
\hline Dyslipidemia [63] & $\begin{array}{l}\text { FPC: simvastatin + ezetimibe or } \\
\text { simvastatin + niacin or lovastatin + niacin); } \\
\text { FDC: simvastatin/ ezetimibe or } \\
\text { simvastatin/ niacin or lovastatin/ niacin }\end{array}$ & Not mentioned & + \\
\hline CVD [62] & $\begin{array}{l}\text { FPC: niacin extended-release + lovastatin } \\
\text { or simvastatin; FDC: niacin } \\
\text { extended-release/ lovastatin }\end{array}$ & Not mentioned & + \\
\hline Dyslipidemia [60] & FPC and FDC: niacin/statin & Not mentioned & + \\
\hline
\end{tabular}


Table A3. Cont.

\begin{tabular}{|c|c|c|c|}
\hline Condition, Reference & $\begin{array}{l}\text { Active Ingredients in the Polypill and } \\
\text { Free-Pill Combination }\end{array}$ & Dose (mg) & $\begin{array}{c}\text { Outcome on Adherence } \\
\text { (+: Improved with Using FDC; } \\
\text {-: Decreased with Using FDC; } \\
\text { 0: No Difference) }\end{array}$ \\
\hline CVD [49] & $\begin{array}{l}\text { FPC: } \mathrm{CCB}+\mathrm{ACEi} \text {; FDC: amlodipine } \\
\text { besylate/benazepril hydrochloride }\end{array}$ & Not mentioned & + \\
\hline HT [75] & FPC: ARB + thiazide; FDC: losartan/HCTZ & FPC: not mentioned; FDC: $50 \mathrm{mg} / 12.5 \mathrm{mg}$ & 0 \\
\hline HT [66] & $\begin{array}{c}\text { FPC: various; FDC: } \\
\text { olmesartan/amlodipine/HCTZ }\end{array}$ & $\begin{array}{c}20 \mathrm{mg} / 5 \mathrm{mg} / 12,5 \mathrm{mg} \text { or } 40 \mathrm{mg} / 5 \mathrm{mg} / 12,5 \mathrm{mg} \text { or } 40 \mathrm{mg} / 5 \mathrm{mg} / 25 \mathrm{mg} \\
\text { or } 40 \mathrm{mg} / 10 \mathrm{mg} / 12,5 \mathrm{mg} \text { or } 40 \mathrm{mg} / 10 \mathrm{mg} / 25 \mathrm{mg}\end{array}$ & + \\
\hline HT [73] & $\begin{array}{l}\text { FPC and FDC: candesartan or valsartan or } \\
\text { telmisartan/amlodipine }\end{array}$ & $\begin{array}{l}\text { ARB (8 mg candesartan or } 80 \mathrm{mg} \text { valsartan or } 40 \mathrm{mg} \text { telmisartan }) / \\
\qquad 5 \mathrm{mg} \text { amlodipine }\end{array}$ & + \\
\hline HT [64] & $\begin{array}{l}\text { FPC and FDC: } \mathrm{ARB} / \text { thiazide diuretic or } \\
\text { ARB/CCB }\end{array}$ & Not mentioned & + \\
\hline HT [67] & $\begin{array}{l}\text { FPC and FDC: ramipril/amlodipine or } \\
\text { candesartan/amlodipine }\end{array}$ & Not mentioned & + \\
\hline HT [69] & FPC and FDC: perindopril/amlodipine & Not mentioned & + \\
\hline HT [71] & $\begin{array}{l}\text { FPC and FDC: RAS } \\
\text { inhibitor/thiazide diuretic }\end{array}$ & Not mentioned & + \\
\hline HT [77] & $\begin{array}{l}\text { FPC and FDC: various } \\
\text { antihypertensive medicines }\end{array}$ & Not mentioned & + \\
\hline HT [79] & $\begin{array}{l}\text { FPC and FDC: ACEi or } \\
\text { ARB/thiazide diuretic }\end{array}$ & Not mentioned & + \\
\hline HT [74] & $\begin{array}{l}\text { FPC and FDC: various } \\
\text { antihypertensive medications }\end{array}$ & Not mentioned & + \\
\hline HT [53] & FPC and FDC: ARB/dihydropyridine CCB & Not mentioned & + \\
\hline HT [42] & FPC and FDC: olmesartan/amlodipine & $20 \mathrm{mg} / 5 \mathrm{mg}$ or $40 \mathrm{mg} / 5 \mathrm{mg}$ or $40 \mathrm{mg} / 10 \mathrm{mg}$ & + \\
\hline HT [76] & $\begin{array}{l}\text { FPC and FDC: various } \\
\text { antihypertensive drugs }\end{array}$ & Not mentioned & 0 \\
\hline HT [5] & FPC and FDC: ARB/thiazide diuretic & Not mentioned & + \\
\hline
\end{tabular}


Table A3. Cont.

\begin{tabular}{|c|c|c|c|}
\hline Condition, Reference & $\begin{array}{l}\text { Active Ingredients in the Polypill and } \\
\text { Free-Pill Combination }\end{array}$ & Dose (mg) & $\begin{array}{c}\text { Outcome on Adherence } \\
\text { (+: Improved with Using FDC; } \\
\text {-: Decreased with Using FDC; } \\
\text { 0: No Difference) }\end{array}$ \\
\hline HT [82] & $\begin{array}{l}\text { FPC: amlodipine + valsartan + } \\
\text { hydrocholorothiazide; FDC: } \\
\text { amlodipine/valsartan/HCTZ }\end{array}$ & Not mentioned & + \\
\hline HT [70] & FPC and FDC: olmesartan/ amlodipine & Not mentioned & + \\
\hline HT [78] & $\begin{array}{l}\text { FPC: ARB + CCB; FDC: } \\
\text { amlodipine/valsartan }\end{array}$ & Not mentioned & + \\
\hline HT [80] & $\begin{array}{l}\text { FPC and FDC: thiazide diuretic/either } \\
\text { ACEi or ARB }\end{array}$ & Not mentioned & + or - \\
\hline HT [81] & $\begin{array}{l}\text { FPC and FDC: olmesartan or } \\
\text { valsartan/HCTZ/amlodipine }\end{array}$ & Not mentioned & + \\
\hline HT [83] & $\begin{array}{c}\text { FPC: ARB or ACEi or BB + amlodipine + } \\
\text { hydrocholorthiazide; FDC: BB/HCTZ + } \\
\text { amlodipine or amlodipine/ARB }+ \text { HCTZ or } \\
\text { ARB/HCTZ + amlodipine or } \\
\text { amlodipine/ACEi + HCTZ or ACEi/HCTZ } \\
+ \text { amlodipine }\end{array}$ & Not mentioned & + \\
\hline HT [65] & $\begin{array}{l}\text { FPC: ARB + CCB; FDC: } \\
\text { valsartan/amlodipine }\end{array}$ & Not mentioned & + \\
\hline HT [72] & $\begin{array}{l}\text { FPC: CCB + statin; FDC: } \\
\text { amlodipine/atorvastatin }\end{array}$ & Not mentioned & + \\
\hline HT [55] & $\begin{array}{c}\text { FPC: ARB + CCB or ARB + HCTZ, or } \\
\text { ACEi + HCTZ; FDC: ARB/CCB or } \\
\text { ARB/HCTZ, or ACEi/HCTZ }\end{array}$ & Not mentioned & + \\
\hline HT [56] & $\begin{array}{c}\text { FPC: ARB + dihydropyridine CCB; FDC: } \\
\text { valsartan/amlodipine or } \\
\text { amlodipine/olmesartan medoxomil }\end{array}$ & Not mentioned & + \\
\hline
\end{tabular}


Table A3. Cont.

\begin{tabular}{|c|c|c|c|}
\hline Condition, Reference & $\begin{array}{l}\text { Active Ingredients in the Polypill and } \\
\text { Free-Pill Combination }\end{array}$ & Dose (mg) & $\begin{array}{c}\text { Outcome on Adherence } \\
\text { (+: Improved with Using FDC; } \\
\text {-: Decreased with Using FDC; } \\
\text { 0: No Difference) }\end{array}$ \\
\hline HT [68] & $\begin{array}{c}\text { FPC: amlodipine + another statin; FDC: } \\
\text { amlodipine/ atorvastatin }\end{array}$ & Not mentioned & + \\
\hline HT [41] & $\begin{array}{c}\text { FPC and FDC: ARB/HCTZ or ACE-I/HCTZ } \\
\text { or ACEi/CCB }\end{array}$ & Not mentioned & + \\
\hline HT [33] & FPC and FDC: valsartan/HCTZ & Not mentioned & + \\
\hline HT [39] & $\begin{array}{l}\text { FPC: CCB + ACEi; FDC: } \\
\text { amlodipine/benazepril }\end{array}$ & Not mentioned & + \\
\hline HT [38] & $\begin{array}{l}\text { FPC: CCB + ACEi; FDC: amlodipine } \\
\text { besylate/benazepril hydrochloride }\end{array}$ & Not mentioned & + \\
\hline HT [46] & $\begin{array}{l}\text { FPC and FDC: amlodipine/atorvastatin or } \\
\text { amlodipine/statin or atorvastatin/CCB or } \\
\text { CCB/statin }\end{array}$ & Not mentioned & + \\
\hline HT [40] & $\begin{array}{l}\text { FPC: CCB + ACEi; FDC: } \\
\text { amlodipine/benazepril }\end{array}$ & Not mentioned & + \\
\hline DMII [85] & FPC and FDC: vildagliptin/metformin & FPC: 50 mg vildagliptin + 850 mg metformin; FDC: not mentioned & + \\
\hline DMII [86] & $\begin{array}{l}\text { FPC and FDC: various oral } \\
\text { antidiabetic drugs }\end{array}$ & Not mentioned & + \\
\hline DMII [84] & FPC and FDC: various oral antidiabetics & Not mentioned & + \\
\hline DMII [31] & FPC and FDC: pioglitazone/metformin & Not mentioned & + \\
\hline DMII [51] & $\begin{array}{l}\text { FPC: thiazolidinedione + sulfonurea; FDC: } \\
\text { rosiglitazone/glimepiride }\end{array}$ & Not mentioned & + \\
\hline DMII [36] & $\begin{array}{l}\text { FPC and FDC: any } 2 \text { oral antidiabetic drugs } \\
\text { (metformin/glyburide/rosiglitazone ... ) }\end{array}$ & Any market-available dose could be included. & + \\
\hline DMII [44] & FPC and FDC: metformin/sulfonylurea & Not mentioned & + \\
\hline
\end{tabular}


Table A3. Cont.

\begin{tabular}{|c|c|c|c|}
\hline Condition, Reference & $\begin{array}{l}\text { Active Ingredients in the Polypill and } \\
\text { Free-Pill Combination }\end{array}$ & Dose (mg) & $\begin{array}{l}\text { Outcome on Adherence } \\
\text { (+: Improved with Using FDC; } \\
\text {-: Decreased with Using FDC; } \\
\text { 0: No Difference) }\end{array}$ \\
\hline DMII [54] & $\begin{array}{l}\text { FPC and FDC: } \\
\text { metformin/thiazolidinedione }\end{array}$ & $\begin{array}{c}2 \mathrm{mg} / 1000 \mathrm{mg} \text { or } 4 \mathrm{mg} / 1000 \mathrm{mg} \text { or } 1 \mathrm{mg} / 500 \mathrm{mg} \text { or } 2 \mathrm{mg} / 500 \mathrm{mg} \text { or } \\
4 \mathrm{mg} / 500 \mathrm{mg}\end{array}$ & + \\
\hline DMII [32] & FPC and FDC: glyburide/metformin & $\begin{array}{l}\text { glyburide from } 6 \text { to } 10 \mathrm{mg} / \text { day/metformin from } 893 \mathrm{mg} \text { to } \\
\qquad 1297 \mathrm{mg} / \text { day }\end{array}$ & + \\
\hline DMII [43] & FPC and FDC: metformin/glyburide & Not mentioned & + or 0 \\
\hline HIV [88] & $\begin{array}{l}\text { FPC: lopinavir/ritonavir }+ \\
\text { zidovudine/lamivudine; FDC: } \\
\text { zidovudine/lamivudine/abacavir }\end{array}$ & $\begin{array}{l}\text { Induction phase: } 150 \mathrm{mg} \text { lamivudine } / 300 \mathrm{mg} \text { zidovudine twice } \\
\text { daily, } 400 \mathrm{mg} \text { lopinavir/100 mg ritonavir twice daily. Test phase: } \\
\text { group } 2 \mathrm{kept} \text { the same regimen, group } 1 \text { switched to } 300 \mathrm{mg} \\
\text { zidovudine } / 600 \mathrm{mg} \text { lamivudine } / 600 \mathrm{mg} \text { abacavir. }\end{array}$ & + \\
\hline HIV [90] & $\begin{array}{l}\text { FPC: various; FDC: } \\
\text { rilpivirine/emtricitabine/tenofovir } \\
\text { disoproxil fumarate }\end{array}$ & Not mentioned & 0 \\
\hline HIV [91] & FPC and FDC: various antiretroviral drugs & Not mentioned & + \\
\hline HIV [34] & $\begin{array}{l}\text { FPC: various; FDC: } \\
\text { efavirenz/emtricitabine/tenofovir }\end{array}$ & Not mentioned & 0 \\
\hline HIV [87] & $\begin{array}{l}\text { FPC: tenofovir + efavirenz + either } \\
\text { emtricitabine or lamivudine; FDC: } \\
\text { emtricitabine/tenofovir/efavirenz }\end{array}$ & Not mentioned & + \\
\hline HIV [30] & $\begin{array}{l}\text { FPC: ritonavir-boosted protease inhibitor + } \\
\text { two NRTIs or NNRTI + two NRTIs; FDC: } \\
\text { efavirenz/emtricibine/tenofovir }\end{array}$ & Not mentioned & + \\
\hline HIV [92] & FPC and FDC: various antiretroviral drugs & Not mentioned & + \\
\hline HIV [94] & FPC and FDC: various antiretroviral drugs & Not mentioned & + \\
\hline HIV [57] & $\begin{array}{c}\text { FPC and FDC: } \\
\text { NRTI/NNRTI/PI/CCR5-antagonist/integrase } \\
\text { inhibitor }\end{array}$ & Not mentioned & + \\
\hline
\end{tabular}


Table A3. Cont.

\begin{tabular}{ccc}
\hline Condition, Reference & $\begin{array}{c}\text { Active Ingredients in the Polypill and } \\
\text { Free-Pill Combination }\end{array}$ & $\begin{array}{c}\text { Outcome on Adherence } \\
\text { Dom) }\end{array}$ \\
\hline HIV [93] & FPC and FDC: various antiretroviral drugs & $\begin{array}{c}\text { Not mentioned } \\
\text { (+: Improved with Using FDC; } \\
\text {-: Decreased with Using FDC; } \\
\text { 0: No Difference) }\end{array}$ \\
\hline HIV [47] & FPC and FDC: various antiretroviral drugs & Not mentioned \\
\hline HIV [50] & $\begin{array}{c}\text { FPC: protease inhibitor + atazanavir or } \\
\text { ritonavir + emtricitabine/tenofivor; } \\
\text { FDC: efavirenz/emtricitabine/tenofovir }\end{array}$ & Not mentioned \\
\hline HIV [37] & $\begin{array}{l}\text { FPC: various antiretroviral drugs; } \\
\text { FDC: tenofovir/emtricitabine/efavirenz }\end{array}$ \\
\hline HIV [89] & FPC and FDC: lamivudine/zidovudine & Not mentioned \\
\hline LUTS/BPH [95] & FPC and FDC: $\alpha$-blocker/antimuscarinic & 150 mg/300 mg \\
\hline
\end{tabular}

FPC, free-pill combination; FDC, fixed-dose combination; HT, hypertension; CVD, cardiovascular disease; DMII, diabetes mellitus type II; HIV, human immunodeficiency virus; LUTS/BPH,

lower urinary tract symptoms associated with benign prostatic hyperplasia; $\mathrm{CCB}$, calcium channel blocker; ACEi, angiotensin-converting enzyme inhibitor; ARB, angiotensin receptor II blocker; RAS, renin-angiotensin system; HCTZ, hydrochlorothiazide; BB, beta-blocker; NRTI, nucleoside/nucleotide reverse transcriptase inhibitor; NNRTI, nonnucleoside/nucleotide reverse transcriptase inhibitor; PI, protease inhibitor; CCR5, chemokine receptor 5 


\section{References}

1. Nieuwlaat, R.; Wilczynski, N.; Navarro, T.; Hobson, N.; Jeffery, R.; Keepanasseril, A.; Agoritsas, T.; Mistry, N.; Iorio, A.; Jack, S.; et al. Interventions for enhancing medication adherence. Cochrane Database Syst. Rev. 2014. [CrossRef]

2. Bangalore, S.; Shahane, A.; Parkar, S.; Messerli, F.H. Compliance and fixed-dose combination therapy. Curr. Hypertens Rep. 2007, 9, 184-189. [CrossRef] [PubMed]

3. Kisa, A.; Sabaté, E.; Nuño-Solinís, R. Adherence to long-term therapies: Evidence for action; WHO: Geneva, Switzerland, 2003; ISBN 9241545992.

4. Hugtenburg, J.G.; Timmers, L.; Elders, P.J.; Vervloet, M.; van Dijk, L. Definitions, variants, and causes of nonadherence with medication: A challenge for tailored interventions. Patient Prefer. Adherence 2013, 7, 675-682. [CrossRef] [PubMed]

5. Hsu, C.-I.; Hsiao, F.-Y.; Wu, F.-L.L.; Shen, L.-J. Adherence and medication utilisation patterns of fixed-dose and free combination of angiotensin receptor blocker/thiazide diuretics among newly diagnosed hypertensive patients: A population-based cohort study. Int. J. Clin. Pract. 2015, 69, 729-737. [CrossRef] [PubMed]

6. Sanz, G.; Fuster, V. Prevention: Polypills for cardiovascular prevention: A step forward? Nat. Rev. Cardiol. 2013, 10, 683-684. [CrossRef]

7. Adeyemi, A.O.; Rascati, K.L.; Lawson, K.A.; Strassels, S.A. Adherence to oral antidiabetic medications in the pediatric population with type 2 diabetes: A retrospective database analysis. Clin. Ther. 2012, 34, 712-719. [CrossRef]

8. Khaled, S.A.; Burley, J.C.; Alexander, M.R.; Yang, J.; Roberts, C.J. 3D printing of five-in-one dose combination polypill with defined immediate and sustained release profiles. J. Control. Release Off. J. Control. Release Soc. 2015, 217, 308-314. [CrossRef]

9. Robles-Martinez, P.; Xu, X.; Trenfield, S.J.; Awad, A.; Goyanes, A.; Telford, R.; Basit, A.W.; Gaisford, S. 3D Printing of a Multi-Layered Polypill Containing Six Drugs Using a Novel Stereolithographic Method. Pharmaceutics 2019, 11, 274. [CrossRef]

10. Moher, D.; Liberati, A.; Tetzlaff, J.; Altman, D.G. Preferred reporting items for systematic reviews and meta-analyses: The PRISMA statement. PLoS Med. 2009, 6, e1000097. [CrossRef]

11. Higgins, J.P.; Altman, D.G.; Gotzsche, P.C.; Juni, P.; Moher, D.; Oxman, A.D.; Savovic, J.; Schulz, K.F.; Weeks, L.; Sterne, J.A. The Cochrane Collaboration's tool for assessing risk of bias in randomised trials. BMJ (Clin. Res. ed.) 2011, 343, d5928. [CrossRef]

12. Wells, G.A.; DO'Connell, B.S.; Peterson, J.; Welch, V.; Losos, M.; Tugwell, P.J. The Newcastle-Ottawa Scale (NOS) for Assessing the Quality of Nonrandomised Studies in Meta-Analyses. Available online: http://www.ohri.ca/programs/clinical_epidemiology/oxford.asp (accessed on 1 November 2019).

13. Bangalore, S.; Kamalakkannan, G.; Parkar, S.; Messerli, F.H. Fixed-dose combinations improve medication compliance: A meta-analysis. Am. J. Med. 2007, 120, 713-719. [CrossRef] [PubMed]

14. Du, L.P.; Cheng, Z.W.; Zhang, Y.X.; Li, Y.; Mei, D. The impact of fixed-dose combination versus free-equivalent combination therapies on adherence for hypertension: A meta-analysis. J. Clin. Hypertens (Greenwich) 2018, 20, 902-907. [CrossRef] [PubMed]

15. Sherrill, B.; Halpern, M.; Khan, S.; Zhang, J.; Panjabi, S. Single-pill vs free-equivalent combination therapies for hypertension: A meta-analysis of health care costs and adherence. J. Clin. Hypertens (Greenwich) 2011, 13, 898-909. [CrossRef] [PubMed]

16. Gupta, A.K.; Arshad, S.; Poulter, N.R. Compliance, safety, and effectiveness of fixed-dose combinations of antihypertensive agents: A meta-analysis. Hypertension 2009, 55, 399-407. [CrossRef] [PubMed]

17. Selak, V.; Webster, R.; Stepien, S.; Bullen, C.; Patel, A.; Thom, S.; Arroll, B.; Bots, M.L.; Brown, A.; Crengle, S.; et al. Reaching cardiovascular prevention guideline targets with a polypill-based approach: A meta-analysis of randomised clinical trials. Heart 2018, 105, 42-48. [CrossRef] [PubMed]

18. Webster, R.; Patel, A.; Selak, V.; Billot, L.; Bots, M.L.; Brown, A.; Bullen, C.; Cass, A.; Crengle, S.; Raina Elley, C.; et al. Effectiveness of fixed dose combination medication ('polypills') compared with usual care in patients with cardiovascular disease or at high risk: A prospective, individual patient data meta-analysis of 3140 patients in six countries. Int. J. Cardiol. 2016, 205, 147-156. [CrossRef] 
19. Ramjan, R.; Calmy, A.; Vitoria, M.; Mills, E.J.; Hill, A.; Cooke, G.; Ford, N. Systematic review and meta-analysis: Patient and programme impact of fixed-dose combination antiretroviral therapy. Trop. Med. Int. Health 2014, 19, 501-513. [CrossRef]

20. Clay, P.G.; Nag, S.; Graham, C.M.; Narayanan, S. Meta-Analysis of Studies Comparing Single and Multi-Tablet Fixed Dose Combination HIV Treatment Regimens. Medicine (Baltimore) 2015, 94, e1677. [CrossRef]

21. Bahiru, E.; de Cates, A.N.; Farr, M.R.; Jarvis, M.C.; Palla, M.; Rees, K.; Ebrahim, S.; Huffman, M.D. Fixed-dose combination therapy for the prevention of atherosclerotic cardiovascular diseases. Cochrane Database Syst. Rev. 2017, 3, Cd009868. [CrossRef]

22. Hutchins, V.; Zhang, B.; Fleurence, R.L.; Krishnarajah, G.; Graham, J. A systematic review of adherence, treatment satisfaction and costs, in fixed-dose combination regimens in type 2 diabetes. Curr. Med. Res. Opin. 2011, 27, 1157-1168. [CrossRef]

23. Albanna, A.S.; Smith, B.M.; Cowan, D.; Menzies, D. Fixed-dose combination antituberculosis therapy: A systematic review and meta-analysis. Eur. Respir. J. 2013, 42, 721-732. [CrossRef] [PubMed]

24. Clay, P.G.; Yuet, W.C.; Moecklinghoff, C.H.; Duchesne, I.; Tronczynski, K.L.; Shah, S.; Shao, D. A meta-analysis comparing 48-week treatment outcomes of single and multi-tablet antiretroviral regimens for the treatment of people living with HIV. AIDS Res. Ther. 2018, 15, 17. [CrossRef] [PubMed]

25. Kawalec, P.; Holko, P.; Gawin, M.; Pilc, A. Effectiveness of fixed-dose combination therapy in hypertension: Systematic review and meta-analysis. Arch. Med. Sci. 2018, 14, 1125-1136. [CrossRef] [PubMed]

26. Mallat, S.G.; Tanios, B.Y.; Itani, H.S.; Lotfi, T.; Akl, E.A. Free versus Fixed Combination Antihypertensive Therapy for Essential Arterial Hypertension: A Systematic Review and Meta-Analysis. PLoS ONE 2016, 11, e0161285. [CrossRef]

27. Altice, F.; Evuarherhe, O.; Shina, S.; Carter, G.; Beaubrun, A.C. Adherence to HIV treatment regimens: Systematic literature review and meta-analysis. Patient Prefer. Adherence 2019, 13, 475-490. [CrossRef]

28. Han, S.; Iglay, K.; Davies, M.J.; Zhang, Q.; Radican, L. Glycemic effectiveness and medication adherence with fixed-dose combination or coadministered dual therapy of antihyperglycemic regimens: A meta-analysis. Curr. Med. Res. Opin. 2012, 28, 969-977. [CrossRef]

29. van Galen, K.A.; Nellen, J.F.; Nieuwkerk, P.T. The Effect on Treatment Adherence of Administering Drugs as Fixed-Dose Combinations versus as Separate Pills: Systematic Review and Meta-Analysis. AIDS Res. Treat. 2014, 2014, 967073. [CrossRef]

30. Bangsberg, D.R.; Ragland, K.; Monk, A.; Deeks, S.G. A single tablet regimen is associated with higher adherence and viral suppression than multiple tablet regimens in HIV+ homeless and marginally housed people. Aids 2010, 24, 2835-2840. [CrossRef]

31. Barner, J.C. Adherence to oral antidiabetic agents with pioglitazone and metformin: Comparison of fixed-dose combination therapy with monotherapy and loose-dose combination therapy. Clin. Ther. 2011, 33, 1281-1288. [CrossRef]

32. Blonde, L.; Wogen, J.; Kreilick, C.; Seymour, A.A. Greater reductions in A1C in type 2 diabetic patients new to therapy with glyburide/metformin tablets as compared to glyburide co-administered with metformin. Diabetes Obes. Metab. 2003, 5, 424-431. [CrossRef]

33. Brixner, D.I.; Jackson, K.C., 2nd; Sheng, X.; Nelson, R.E.; Keskinaslan, A. Assessment of adherence, persistence, and costs among valsartan and hydrochlorothiazide retrospective cohorts in free-and fixed-dose combinations. Curr. Med. Res. Opin. 2008, 24, 2597-2607. [CrossRef] [PubMed]

34. Buscher, A.; Hartman, C.; Kallen, M.A.; Giordano, T.P. Impact of antiretroviral dosing frequency and pill burden on adherence among newly diagnosed, antiretroviral-naive HIV patients. Int. J. STD AIDS 2012, 23, 351-355. [CrossRef] [PubMed]

35. Castellano, J.M.; Sanz, G.; Penalvo, J.L.; Bansilal, S.; Fernandez-Ortiz, A.; Alvarez, L.; Guzman, L.; Linares, J.C.; Garcia, F.; D'Aniello, F.; et al. A polypill strategy to improve adherence: Results from the FOCUS project. J. Am. Coll. Cardiol. 2014, 64, 2071-2082. [CrossRef] [PubMed]

36. Cheong, C.; Barner, J.C.; Lawson, K.A.; Johnsrud, M.T. Patient adherence and reimbursement amount for antidiabetic fixed-dose combination products compared with dual therapy among Texas Medicaid recipients. Clin. Ther. 2008, 30, 1893-1907. [CrossRef]

37. Cohen, C.J.; Meyers, J.L.; Davis, K.L. Association between daily antiretroviral pill burden and treatment adherence, hospitalisation risk, and other healthcare utilisation and costs in a US medicaid population with HIV. BMJ Open 2013, 3, e003028. [CrossRef] 
38. Dickson, M.; Plauschinat, C.A. Racial differences in medication compliance and healthcare utilization among hypertensive Medicaid recipients: Fixed-dose vs free-combination treatment. Ethn. Dis. 2008, 18, 204-209.

39. Dickson, M.; Plauschinat, C.A. Compliance with antihypertensive therapy in the elderly: A comparison of fixed-dose combination amlodipine/benazepril versus component-based free-combination therapy. Am. J. Cardiovasc. Drugs 2008, 8, 45-50. [CrossRef]

40. Gerbino, P.P.; Shoheiber, O. Adherence patterns among patients treated with fixed-dose combination versus separate antihypertensive agents. Am. J. Health Syst. Pharm. 2007, 64, 1279-1283. [CrossRef]

41. Hess, G.; Hill, J.; Lau, H.; Dastani, H.; Chaudhari, P. Medication Utilization Patterns and Hypertension-Related Expenditures among Patients Who Were Switched from Fixed-Dose to Free-Combination Antihypertensive Therapy. Pharm. Ther. 2009, 33, 652-666.

42. Levi, M.; Pasqua, A.; Cricelli, I.; Cricelli, C.; Piccinni, C.; Parretti, D.; Lapi, F. Patient Adherence to Olmesartan/Amlodipine Combinations: Fixed Versus Extemporaneous Combinations. J. Manag. Care Spec. Pharm. 2016, 22, 255-262. [CrossRef]

43. Melikian, C.; White, T.J.; Vanderplas, A.; Dezii, C.M.; Chang, E. Adherence to oral antidiabetic therapy in a managed care organization: A comparison of monotherapy, combination therapy, and fixed-dose combination therapy. Clin. Ther. 2002, 24, 460-467. [CrossRef]

44. Pan, F.; Chernew, M.E.; Fendrick, A.M. Impact of fixed-dose combination drugs on adherence to prescription medications. J. Gen. Intern. Med. 2008, 23, 611-614. [CrossRef] [PubMed]

45. Patel, A.; Cass, A.; Peiris, D.; Usherwood, T.; Brown, A.; Jan, S.; Neal, B.; Hillis, G.S.; Rafter, N.; Tonkin, A.; et al. A pragmatic randomized trial of a polypill-based strategy to improve use of indicated preventive treatments in people at high cardiovascular disease risk. Eur. J. Prev. Cardiol. 2014, 22, 920-930. [CrossRef] [PubMed]

46. Patel, B.V.; Leslie, R.S.; Thiebaud, P.; Nichol, M.B.; Tang, S.S.; Solomon, H.; Honda, D.; Foody, J.M. Adherence with single-pill amlodipine/atorvastatin vs a two-pill regimen. Vasc. Health Risk Manag. 2008, 4, 673-681. [PubMed]

47. Raffi, F.; Yazdanpanah, Y.; Fagnani, F.; Laurendeau, C.; Lafuma, A.; Gourmelen, J. Persistence and adherence to single-tablet regimens in HIV treatment: A cohort study from the French National Healthcare Insurance Database. J. Antimicrob. Chemother. 2015, 70, 2121-2128. [CrossRef] [PubMed]

48. Selak, V.; Elley, C.R.; Bullen, C.; Crengle, S.; Wadham, A.; Rafter, N.; Parag, V.; Harwood, M.; Doughty, R.N.; Arroll, B.; et al. Effect of fixed dose combination treatment on adherence and risk factor control among patients at high risk of cardiovascular disease: Randomised controlled trial in primary care. BMJ (Clin. Res. ed.) 2014, 348, g3318. [CrossRef]

49. Taylor, A.A.; Shoheiber, O. Adherence to antihypertensive therapy with fixed-dose amlodipine besylate/benazepril $\mathrm{HCl}$ versus comparable component-based therapy. Congest. Heart Fail. 2003, 9, 324-332. [CrossRef]

50. Tennant, S.J.; Hester, E.K.; Caulder, C.R.; Lu, Z.K.; Bookstaver, P.B. Adherence among rural HIV-infected patients in the deep south: A comparison between single-tablet and multi-tablet once-daily regimens. J. Int. Assoc. Provid. AIDS Care 2014, 14, 64-71. [CrossRef]

51. Thayer, S.; Arondekar, B.; Harley, C.; Darkow, T.E. Adherence to a fixed-dose combination of rosiglitazone/glimepiride in subjects switching from monotherapy or dual therapy with a thiazolidinedione and/or a sulfonylurea. Ann. Pharmacother. 2010, 44, 791-799. [CrossRef]

52. Thom, S.; Poulter, N.; Field, J.; Patel, A.; Prabhakaran, D.; Stanton, A.; Grobbee, D.E.; Bots, M.L.; Reddy, K.S.; Cidambi, R.; et al. Effects of a fixed-dose combination strategy on adherence and risk factors in patients with or at high risk of CVD: The UMPIRE randomized clinical trial. JAMA 2013, 310, 918-929. [CrossRef]

53. Tung, Y.C.; Huang, Y.C.; Wu, L.S.; Chang, C.J.; Chu, P.H. Medication compliance and clinical outcomes of fixed-dose combinations vs free combinations of an angiotensin II receptor blocker and a calcium channel blocker in hypertension treatment. J. Clin. Hypertens (Greenwich) 2017, 19, 983-989. [CrossRef] [PubMed]

54. Vanderpoel, D.R.; Hussein, M.A.; Watson-Heidari, T.; Perry, A. Adherence to a fixed-dose combination of rosiglitazone maleate/metformin hydrochloride in subjects with type 2 diabetes mellitus: A retrospective database analysis. Clin. Ther. 2005, 26, 2066-2075. [CrossRef] [PubMed]

55. Yang, W.; Chang, J.; Kahler, K.H.; Fellers, T.; Orloff, J.; Wu, E.Q.; Bensimon, A.G. Evaluation of compliance and health care utilization in patients treated with single pill vs. free combination antihypertensives. Curr. Med. Res. Opin. 2010, 26, 2065-2076. [CrossRef] [PubMed] 
56. Zeng, F.; Patel, B.V.; Andrews, L.; Frech-Tamas, F.; Rudolph, A.E. Adherence and persistence of single-pill ARB/CCB combination therapy compared to multiple-pill ARB/CCB regimens. Curr. Med. Res. Opin. 2010, 26, 2877-2887. [CrossRef] [PubMed]

57. Sutton, S.S.; Hardin, J.W.; Bramley, T.J.; D'Souza, A.O.; Bennett, C.L. Single- versus multiple-tablet HIV regimens: Adherence and hospitalization risks. Am. J. Manag. Care 2016, 22, 242-248. [PubMed]

58. Bartlett, L.E.; Pratt, N.; Roughead, E.E. Does tablet formulation alone improve adherence and persistence: A comparison of ezetimibe fixed dose combination versus ezetimibe separate pill combination? Br. J. Clin. Pharmacol. 2016, 83, 202-210. [CrossRef]

59. Lafeber, M.; Grobbee, D.E.; Schrover, I.M.; Thom, S.; Webster, R.; Rodgers, A.; Visseren, F.L.; Bots, M.L.; Spiering, W. Comparison of a morning polypill, evening polypill and individual pills on LDL-cholesterol, ambulatory blood pressure and adherence in high-risk patients; a randomized crossover trial. Int. J. Cardiol. 2014, 181, 193-199. [CrossRef]

60. LaFleur, J.; Thompson, C.J.; Joish, V.N.; Charland, S.L.; Oderda, G.M.; Brixner, D.I. Adherence and persistence with single-dosage form extended-release niacin/lovastatin compared with statins alone or in combination with extended-release niacin. Ann. Pharmacother. 2006, 40, 1274-1279. [CrossRef]

61. Schaffer, A.L.; Buckley, N.A.; Pearson, S.A. Who benefits from fixed-dose combinations? Two-year statin adherence trajectories in initiators of combined amlodipine/atorvastatin therapy. Pharmacoepidemiol. Drug Saf. 2017, 26, 1465-1473. [CrossRef]

62. Balu, S.; Simko, R.J.; Quimbo, R.M.; Cziraky, M.J. Impact of fixed-dose and multi-pill combination dyslipidemia therapies on medication adherence and the economic burden of sub-optimal adherence. Curr. Med. Res. Opin. 2009, 25, 2765-2775. [CrossRef]

63. Kamat, S.A.; Bullano, M.F.; Chang, C.L.; Gandhi, S.K.; Cziraky, M.J. Adherence to single-pill combination versus multiple-pill combination lipid-modifying therapy among patients with mixed dyslipidemia in a managed care population. Curr. Med. Res. Opin. 2011, 27, 961-968. [CrossRef] [PubMed]

64. Ah, Y.M.; Shin, J.; Lee, J.Y. The association of angiotensin receptor blocker-based combination therapy with persistence and adherence in newly treated, uncomplicated hypertensive patients. Patient Prefer. Adherence 2019, 13, 241-248. [CrossRef] [PubMed]

65. Baser, O.; Andrews, L.M.; Wang, L.; Xie, L. Comparison of real-world adherence, healthcare resource utilization and costs for newly initiated valsartan/amlodipine single-pill combination versus angiotensin receptor blocker/calcium channel blocker free-combination therapy. J. Med. Econ. 2011, 14, 576-583. [CrossRef] [PubMed]

66. Bramlage, P.; Ketelhut, R.; Fronk, E.M.; Wolf, W.P.; Smolnik, R.; Zemmrich, C.; Schmieder, R.E. Clinical impact of patient adherence to a fixed-dose combination of olmesartan, amlodipine and hydrochlorothiazide. Clin. Drug Investig. 2014, 34, 403-411. [CrossRef]

67. Bramlage, P.; Schmidt, S.; Sims, H. Fixed-dose vs free-dose combinations for the management of hypertension-An analysis of 81958 patients. J. Clin. Hypertens (Greenwich) 2018, 20, 705-715. [CrossRef]

68. Chapman, R.H.; Pelletier, E.M.; Smith, P.J.; Roberts, C.S. Can adherence to antihypertensive therapy be used to promote adherence to statin therapy? Patient Prefer. Adherence 2009, 3, 265-275. [CrossRef]

69. Degli Esposti, L.; Perrone, V.; Veronesi, C.; Gambera, M.; Nati, G.; Perone, F.; Tagliabue, P.F.; Buda, S.; Borghi, C. Modifications in drug adherence after switch to fixed-dose combination of perindopril/amlodipine in clinical practice. Results of a large-scale Italian experience. The amlodipine-perindopril in real settings (AMPERES) study. Curr. Med. Res. Opin. 2018, 34, 1571-1577. [CrossRef]

70. Degli Esposti, L.; Saragoni, S.; Buda, S.; Degli Esposti, E. Drug adherence to olmesartan/amlodipine fixed combination in an Italian clinical practice setting. Clin. Outcomes Res. 2014, 6, 209-216. [CrossRef]

71. Ho, C.T.; Tung, Y.C.; Chou, S.H.; Hsiao, F.C.; Lin, Y.S.; Chang, C.J.; Chu, P.H. Clinical outcomes in hypertensive patients treated with a single-pill fixed-dose combination of renin-angiotensin system inhibitor and thiazide diuretic. J. Clin. Hypertens (Greenwich) 2018, 20, 1731-1738. [CrossRef]

72. Hussein, M.A.; Chapman, R.H.; Benner, J.S.; Tang, S.S.; Solomon, H.A.; Joyce, A.; Foody, J.M. Does a single-pill antihypertensive/lipid-lowering regimen improve adherence in US managed care enrolees? A non-randomized, observational, retrospective study. Am. J. Cardiovasc. Drugs 2010, 10, 193-202. [CrossRef] 
73. Kumagai, N.; Onishi, K.; Hoshino, K.; Nakamori, S.; Kitai, T.; Yazu, T.; Oota, M.; Ueda, Y.; Hiraoka, N.; Okamoto, S.; et al. Improving drug adherence using fixed combinations caused beneficial treatment outcomes and decreased health-care costs in patients with hypertension. Clin. Exp. Hypertens 2012, 35, 355-360. [CrossRef] [PubMed]

74. Lauffenburger, J.C.; Landon, J.E.; Fischer, M.A. Effect of Combination Therapy on Adherence Among US Patients Initiating Therapy for Hypertension: A Cohort Study. J. Gen. Intern. Med. 2017, 32, 619-625. [CrossRef] [PubMed]

75. Matsumura, K.; Arima, H.; Tominaga, M.; Ohtsubo, T.; Sasaguri, T.; Fujii, K. Does a combination pill of antihypertensive drugs improve medication adherence in Japanese? J. hypertension. 2012, 30, e251. [CrossRef]

76. Sonawane Deshmukh, K.B.; Qian, J.; Garza, K.B.; Wright, B.M.; Zeng, P.; Ganduglia Cazaban, C.M.; Hansen, R.A. Achieving Adherence After First-Line Antihypertensive Treatment: Should Fixed-Dose Combinations Receive Priority? J. Clin. Hypertens (Greenwich) 2016, 18, 934-941. [CrossRef] [PubMed]

77. Tilea, I.; Petra, D.; Voidazan, S.; Ardeleanu, E.; Varga, A. Treatment adherence among adult hypertensive patients: A cross-sectional retrospective study in primary care in Romania. Patient Prefer. Adherence 2018, 12, 625-635. [CrossRef] [PubMed]

78. Tung, Y.C.; Lin, Y.S.; Wu, L.S.; Chang, C.J.; Chu, P.H. Clinical outcomes and healthcare costs in hypertensive patients treated with a fixed-dose combination of amlodipine/valsartan. J. Clin. Hypertens (Greenwich) 2014, 17, 51-58. [CrossRef]

79. Verma, A.A.; Khuu, W.; Tadrous, M.; Gomes, T.; Mamdani, M.M. Fixed-dose combination antihypertensive medications, adherence, and clinical outcomes: A population-based retrospective cohort study. PLoS Med. 2018, 15, e1002584. [CrossRef]

80. Wang, T.D.; Chen, Y.H.; Huang, C.H.; Chen, W.J.; Chen, M.F. Bidirectional adherence changes and associated factors in patients switched from free combinations to equivalent single-pill combinations of antihypertensive drugs. Hypertension 2014, 63, 958-967. [CrossRef]

81. Xie, L.; Frech-Tamas, F.; Marrett, E.; Baser, O. A medication adherence and persistence comparison of hypertensive patients treated with single-, double- and triple-pill combination therapy. Curr. Med. Res. Opin. 2014, 30, 2415-2422. [CrossRef]

82. Machnicki, G.; Ong, S.H.; Chen, W.; Wei, Z.J.; Kahler, K.H. Comparison of amlodipine/valsartan/ hydrochlorothiazide single pill combination and free combination: Adherence, persistence, healthcare utilization and costs. Curr. Med. Res. Opin. 2015, 31, 2287-2296. [CrossRef]

83. Panjabi, S.; Lacey, M.; Bancroft, T.; Cao, F. Treatment adherence, clinical outcomes, and economics of triple-drug therapy in hypertensive patients. J. Am. Soc. Hypertens. 2013, 7, 15. [CrossRef] [PubMed]

84. Vittorino Gaddi, A.; Benedetto, D.; Capello, F.; Di Pietro, C.; Cinconze, E.; Rossi, E.; De Sando, V.; Cevenini, M.; D'Alo, G. Oral antidiabetic therapy in a large Italian sample: Drug supply and compliance for different therapeutic regimens. Public Health 2013, 128, 70-76. [CrossRef] [PubMed]

85. Rombopoulos, G.; Hatzikou, M.; Athanasiadis, A.; Elisaf, M. Treatment Compliance with Fixed-Dose Combination of Vildagliptin/Metformin in Patients with Type 2 Diabetes Mellitus Inadequately Controlled with Metformin Monotherapy: A 24-Week Observational Study. Int. J. Endocrinol. 2015, 2015, 251485. [CrossRef] [PubMed]

86. Lokhandwala, T.; Smith, N.; Sternhufvud, C.; Sorstadius, E.; Lee, W.C.; Mukherjee, J. A retrospective study of persistence, adherence, and health economic outcomes of fixed-dose combination vs. loose-dose combination of oral anti-diabetes drugs. J. Med. Econ. 2015, 19, 203-212. [CrossRef]

87. Airoldi, M.; Zaccarelli, M.; Bisi, L.; Bini, T.; Antinori, A.; Mussini, C.; Bai, F.; Orofino, G.; Sighinolfi, L.; Gori, A.; et al. One-pill once-a-day HAART: A simplification strategy that improves adherence and quality of life of HIV-infected subjects. Patient Prefer. Adherence 2010, 4, 115-125.

88. Langebeek, N.; Sprenger, H.; Gisolf, E.; Reiss, P.; Sprangers, M.; Legrand, J.; Richter, C.; Nieuwkerk, P. A simplified combination antiretroviral therapy regimen enhances adherence, treatment satisfaction and quality of life: Results of a randomized clinical trial. HIV Med. 2014, 15, 286-290. [CrossRef]

89. Legorreta, A.; Yu, A.; Chernicoff, H.; Gilmore, A.; Jordan, J.; Rosenzweig, J.C. Adherence to combined Lamivudine + Zidovudine versus individual components: A community-based retrospective medicaid claims analysis. AIDS Care 2005, 17, 938-948. [CrossRef] 
90. Arrabal-Duran, P.; Rodriguez-Gonzalez, C.G.; Chamorro-de-Vega, E.; Gijon-Vidaurreta, P.; Herranz-Alonso, A.; Sanjurjo-Saez, M. Switching to a rilpivirine/emtricitabine/tenofovir single-tablet regimen in RNA-suppressed patients infected with human immunodeficiency virus 1: Effectiveness, safety and costs at 96 weeks. Int. J. Clin. Pract. 2017, 71. [CrossRef]

91. Chen, Y.; Chen, K.; Kalichman, S.C. Barriers to HIV Medication Adherence as a Function of Regimen Simplification. Ann. Behav. Med. 2016, 51, 67-78. [CrossRef]

92. Santoleri, F.; Lasala, R.; Logreco, A.; Ammazzalorso, A.; Fantacuzzi, M.; Amoroso, R.; Costantini, A. Time factor in antiretroviral adherence: Analysis of adherence to single-tablet regimens versus multiple-tablet regimens over a 5-year period. Drugs Ther. Perspect. 2018, 34, 263-268. [CrossRef]

93. Scott Sutton, S.; Magagnoli, J.; Hardin, J.W. Impact of Pill Burden on Adherence, Risk of Hospitalization, and Viral Suppression in Patients with HIV Infection and AIDS Receiving Antiretroviral Therapy. Pharmacotherapy 2016, 36, 385-401. [CrossRef]

94. Yager, J.; Faragon, J.; McGuey, L.; Hoye-Simek, A.; Hecox, Z.; Sullivan, S.; Neubert, S.; Patel, N. Relationship Between Single Tablet Antiretroviral Regimen and Adherence to Antiretroviral and Non-Antiretroviral Medications Among Veterans' Affairs Patients with Human Immunodeficiency Virus. AIDS Patient Care STDS 2017, 31, 370-376. [CrossRef]

95. Drake, M.J.; Bowditch, S.; Arbe, E.; Hakimi, Z.; Guelfucci, F.; Amri, I.; Nazir, J. A retrospective study of treatment persistence and adherence to $\alpha$-blocker plus antimuscarinic combination therapies, in men with LUTS/BPH in the Netherlands. BMC Urol. 2017, 17. [CrossRef]

96. Ezzati, M.; Lopez, A.D.; Rodgers, A.; Vander Hoorn, S.; Murray, C.J. Selected major risk factors and global and regional burden of disease. Lancet 2002, 360, 1347-1360. [CrossRef]

97. Kwon, K.C.; Lee, C. Analysis of Fixed-Dose Combination Products Approved by the US Food and Drug Administration, 2010-2015: Implications for Designing a Regulatory Shortcut to New Drug Application. Ther. Innov. Regul. Sci. 2017, 51, 111-117. [CrossRef]

98. Angeli, F.; Reboldi, G.; Mazzotta, G.; Garofoli, M.; Ramundo, E.; Poltronieri, C.; Verdecchia, P. Fixed-dose combination therapy in hypertension: Cons. High Blood Press. Cardiovasc. Prev. Off. J. Ital. Soc. Hypertens. 2012, 19, 51-54. [CrossRef]

99. Kim, H.; Yoon, H.J.; Park, H.S.; Cho, Y.K.; Nam, C.W.; Han, S.; Hur, S.H.; Kim, Y.N.; Kim, K.B. Implications of prescribing a fixed-dose combination in clinical cardiology practice: A retrospective observational study using a single medical centre database in Korea. Heart Asia 2017, 9, e010885. [CrossRef]

100. Orloff, D.G. Fixed combination drugs for cardiovascular disease risk reduction: Regulatory approach. Am. J. Cardiol. 2005, 96, 28K-33K, discussion 34K-35K. [CrossRef]

101. Shenfield, G.M. Fixed combination drug therapy. Drugs 1982, 23, 462-480. [CrossRef] 